\title{
Egy új típusú szulfid kinon oxidoreduktáz funkcionális és müködési analízise
}

\author{
Ph.D. értekezés
}

Duzs Ágnes

\author{
Témavezetők: \\ Dr. Tóth András \\ Dr. Rákhely Gábor
}

Biológia Doktori Iskola

\begin{abstract}
Szegedi Tudományegyetem, Biotechnológiai Tanszék
Magyar Tudományos Akadémia, Szegedi Biológiai Kutatóközpont,

Biofizikai Intézet
\end{abstract}

SZTE TTIK

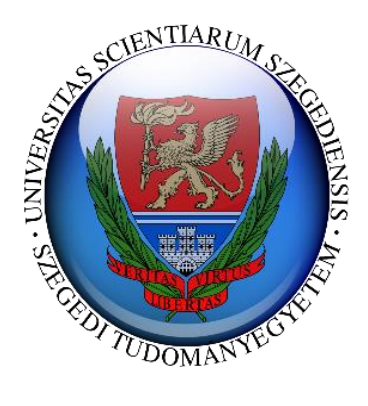

2018

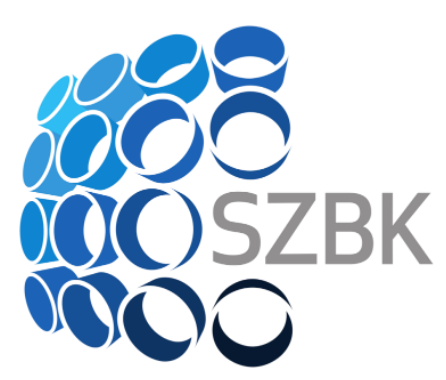

Szeged 


\section{Tartalomjegyzék}

TARTALOMJEGYZÉK ...................................................................................... 2

1. RÖVIDÍTÉSEK JEGYZÉKE ...................................................................6

2. BEVEZETÉS ................................................................................................

2.1. SZULFID ELŐFORDULÁSA A TERMÉSZETBEN …………………………………..... 8

2.2. SZULFID SZEREPE AZ ÉLỎVILÁGBAN...................................................................... 8

2.3. SZULFID FELHASZNÁLÓ MIKROORGANIZMUSOK …………………………………... 9

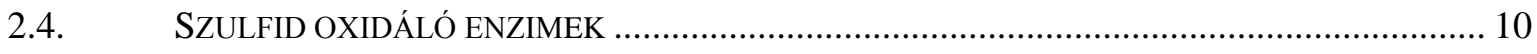

2.5. SZULFID KINON OXIDOREDUKTÁZ (SQR) FEHÉRJÉK ………………………………...... 12

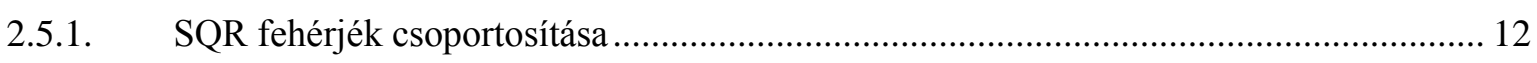

2.5.2. $\quad s q r$ gének expressziós szabályozása.................................................................... 17

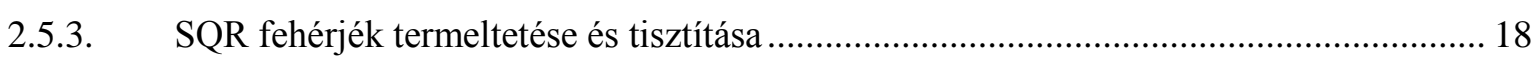

2.5.4. SQR fehérjék szerkezete ............................................................................ 19

2.5.4.1. Az SQR fehérjék FAD kofaktor kötése ........................................................................... 20

2.5.4.2. A szulfid útvonala $\mathrm{SQR}$ fehérjékben .............................................................................. 20

2.5.4.3. SQR fehérjék C-terminális régiója .................................................................................... 21

2.5.5. Az SQR enzimek katalitikus müködése...…………………………………….... 22

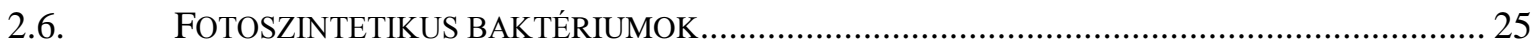

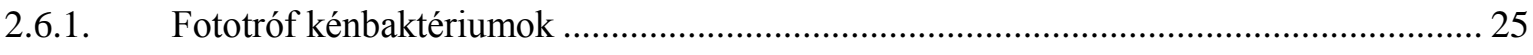

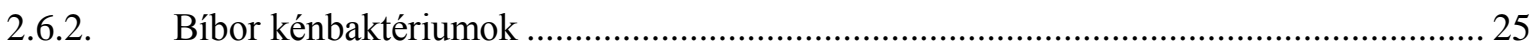

2.6.3. Fotoszintetikus bíbor kénbaktériumok szulfid anyagcseréje ........................................ 26

2.6.4. Thiocapsa roseopersicina BBS .............................................................................. 26

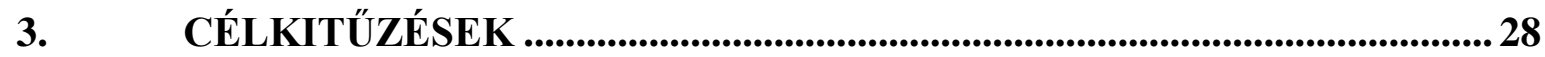

4. ANYAGOK ÉS MÓDSZEREK …………..........................................................29

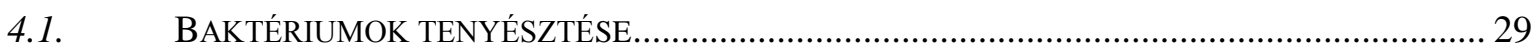

4.1.1. E. coli törzsek tenyésztési körülményei................................................................... 29

4.1.2. T. roseopersicina törzsek tenyésztési körülményei ………………………………….... 29

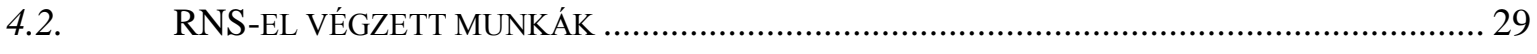

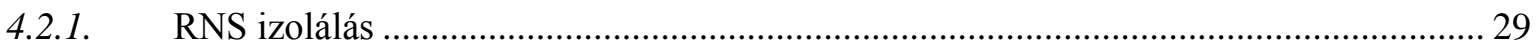

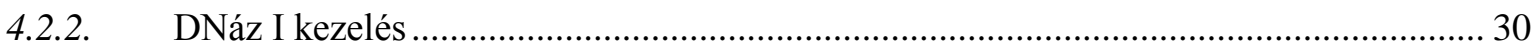

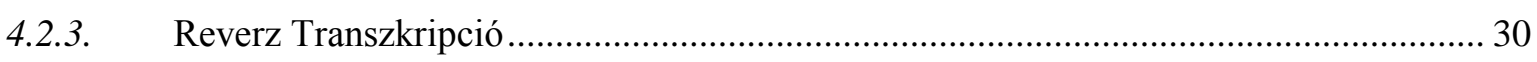

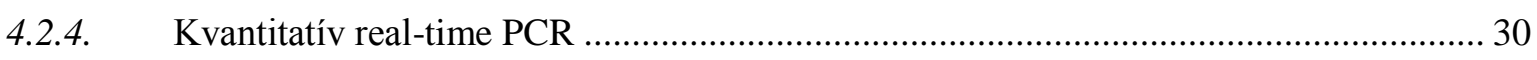

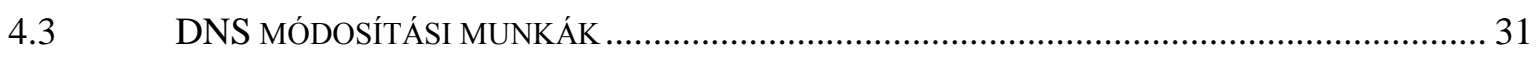

4.3.1. Plazmid DNS izolálás E. coli-ból ............................................................................. 31 


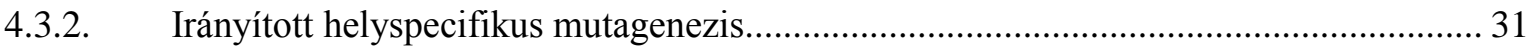

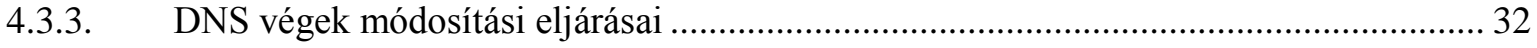

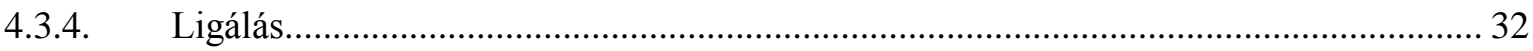

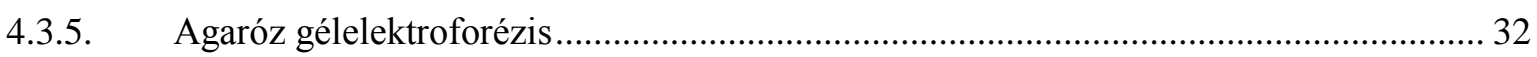

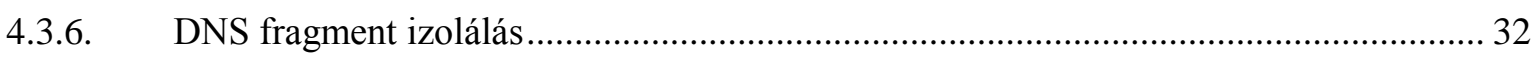

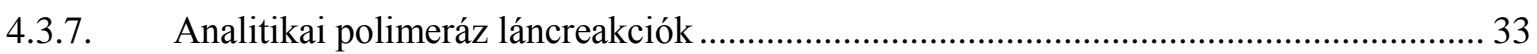

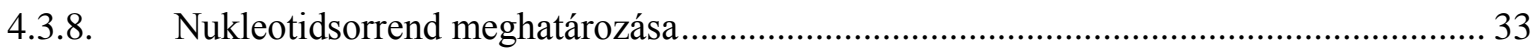

4.3.9. $\quad s q r D$ és $s q r F$ gének csonkítását eredményező DNS konstrukciók előállítása ................. 33

4.3.10. Rekombináns SqrD és SqrF fehérjét termelő expressziós vektorok ............................... 34

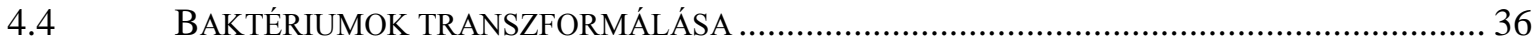

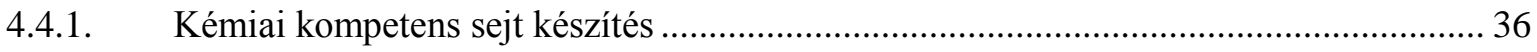

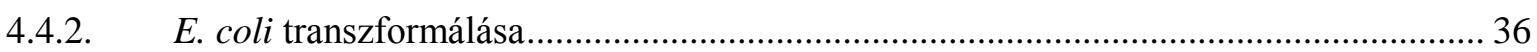

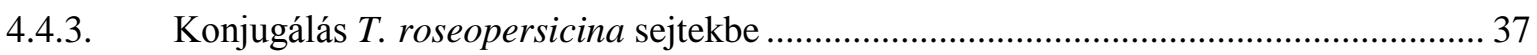

4.4.4. $\quad$ sqr génekben mutáns T. roseopersicina törzsek ellenörzése ......................................... 37

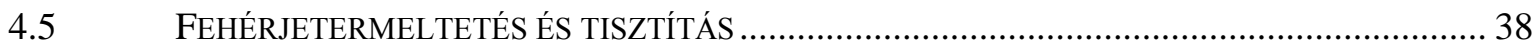

4.5.1. Fehérjetermelő E. coli sejtek feltárása, membrán frakció előállítása.............................. 38

4.5.2. Fehérjetermelő T. roseopersicina sejtek feltárása, membrán frakció előállítása ............. 38

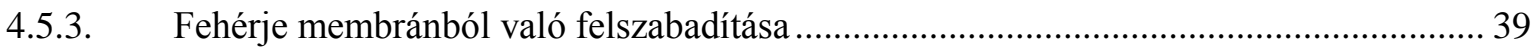

4.5.4. Fehérje tisztítás affinitás oszlop kromatográfiával .......................................................... 39

4.6 POLIAKRILAMID GÉLELEKTROFORÉZIS TECHNIKÁK ..................................................... 40

4.6.1. Denaturáló poliakrilamid gélelektroforézis (SDS-PAGE) ........................................... 40

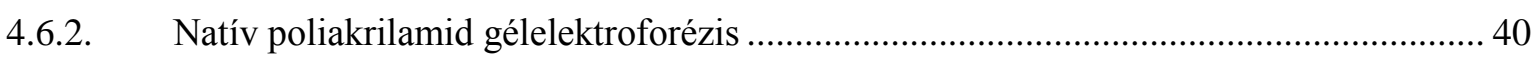

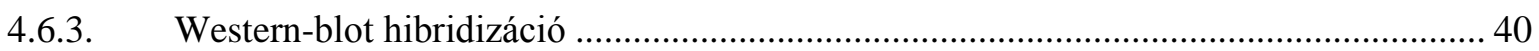

4.7 TISZTÍTOTT FEHÉRJÉK JELLEMZÉSÉHEZ ALKALMAZOTT MÓDSZEREK............................ 41

4.7.1. Fehérje mennyiség meghatározás Micro-Lowry módszerrel........................................... 41

4.7.2. Fehérje abszorpciós és emissziós spektrum meghatározás .............................................. 41

4.7.3. Szulfid függő kinon redukáló aktivitás mérés ................................................................ 41

4.7.4. SqrF enzim aktivációs energiájának meghatározása............................................................. 42

4.7.5. Tisztított fehérje FAD kofaktor tartalmának és kötésének vizsgálata ............................ 42

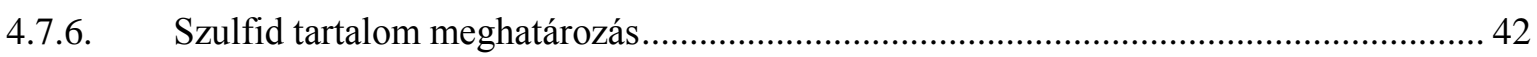

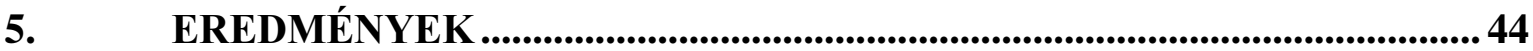

5.1. AZ SQRD ÉS SQRF GÉNEK AZONOSÍTÁSA ÉS IN SILICO ANALÍZISE .................................... 44

5.2. AZ SQRD ÉS SQRF GÉNEK KIFEJEZÖDÉSE T. ROSEOPERSICINA-BAN ................................. 48

5.3. SZULFID KINON OXIDOREDUKTÁZOK RÉSZVÉTELE A T. ROSEOPERSICINA

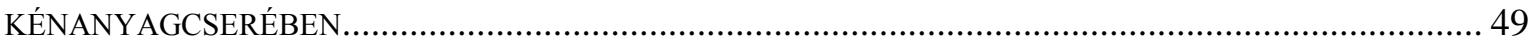

5.3.1. Membrán kötött SqrD és SqrF fehérjék aktivitás vizsgálata in vitro ............................... 49 
5.3.2. SqrD és SqrF fehérjék aktivitás vizsgálata in vivo....................................................... 50

5.4. AZ SQRD ÉS SQRF FEHÉRJÉK EXPRESSZIÓJA ÉS TISZTÍTÁSA …...................................... 52

5.4.1. Az SqrD és SqrF fehérjéket termelő expressziós vektorok............................................ 52

5.4.2. Rekombináns SqrD és SqrF fehérje termeltetése és tisztítása T. roseopersicina-ban .... 52

5.5. A TISZTÍTOTT SQRF FEHÉRJE JELLEMZÉSE, TULAJDONSÁGAI............................................... 60

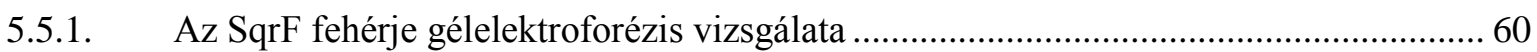

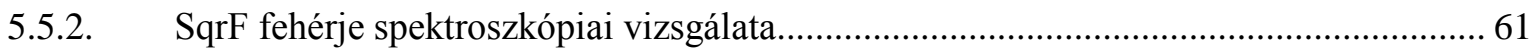

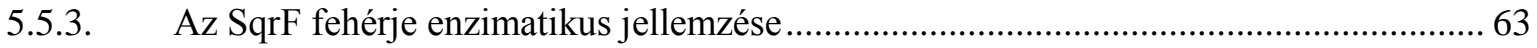

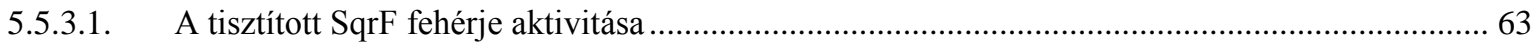

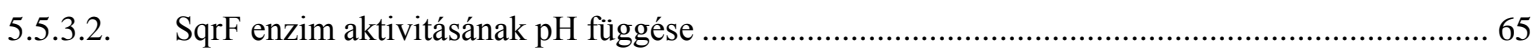

5.5.3.3. Az SqrF enzim aktivitásának hőmérsékletfüggése, aktiválási energiái ......................................... 66

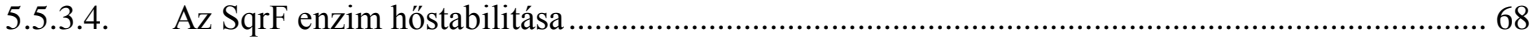

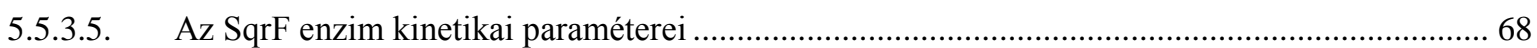

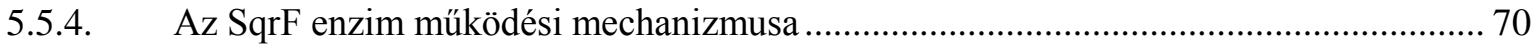

5.5.4.1. SqrF fehérje variánsok gélelektroforézis vizsgálata .................................................................. 71

5.5.4.2. Az SqrF fehérje variánsok spektroszkópiai és katalítikus vizsgálata ........................................... 72

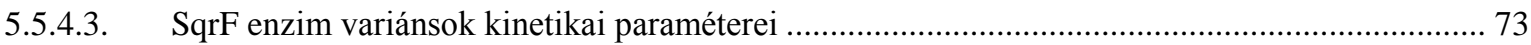

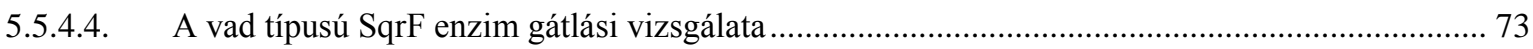

5.5.4.5. Cisztein mutáns SqrF variáns enzimek gátlási vizsgálata ........................................................... 75

5.5.4.6. A vad típusú SqrF enzim FAD kötésének vizsgálata jódacetamid jelenlétében............................. 75

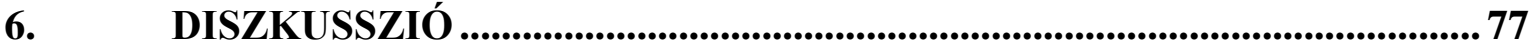

6.1. SZULFID KINON OXIDOREDUKTÁZOK THIOCAPSA ROSEOPERSICINA-BAN ....................... 77

6.2. REKOMBINÁNIS SZULFID KINON OXIDOREDUKTÁZOK TERMELTETÉSE ÉS TISZÍTÁSA .... 79

6.3. A TISZTÍTOTT SQRF FEHÉRJE BIOKÉMIAI SAJÁTSÁGAI .................................................. 81

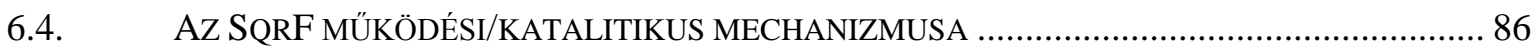

7. KÖSZÖNETNYILVÁNÍTÁS............................................................................90

8. HIVATKOZÁSOK JEGYZÉKE ..................................................................... 91

9. ÖSSZEFOGLALÁS

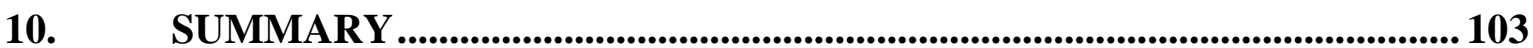

11. FÜGGELÉK …................................................................................................ 106

11.1. FELHASZNÁLT OLDATOK, TÖRZSEK, PLAZMIDOK, OLIGONUKLEOTIDOK ....................... 106

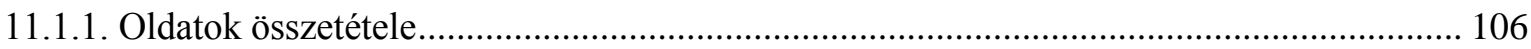

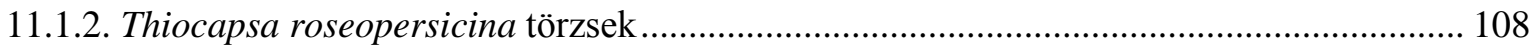

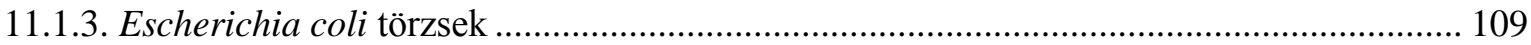


11.1.4. Plazmidok megnevezése és leírása

11.1.5. Oligonukleotidok megnevezése és szekvenciája...

11.1.6. A kvantitatív real-time PCR során használt oligonukleotidok. 


\section{Röviditések jegyzéke}

Amp: ampicillin

APS: ammónium-perszulfát

ATP: $\quad$ adenozin-trifoszfát

DDM: $\quad \mathrm{N}$-dodecil $\beta$-D-maltozid

DEPC: dietil-pirokarbonát

DMSO: dimetil-szulfoxid

DNS: dezoxiribonukleinsav

dNTP: dezoxinukleozid-trifoszfát

DQ: durokinon

dUQ: decilubikinon

EDTA: etilén-diamin-tetraecetsav

FastAP: hőérzékeny alkalikus foszfatáz

Gm: gentamicin

IPTG: $\quad$ izopropil $\beta$-D-1-tiogalaktopiranozid

$\mathrm{Km}: \quad$ kanamicin

LB: $\quad$ Luria-Bertani

LDAO: $\quad$ Laurildimetilamin-N-oxid

MMLV: Moloney Murine Leukemia Virus

$\mathrm{Na}_{2} \mathrm{~S}: \quad$ nátrium-szulfid

OD: $\quad$ optikai denzitás

RT-PCR: valós idejü polimeráz láncreakció

SDS: nátrium-dodecil-szulfát

SDS-PAGE: denaturáló poliakrilamid gélelektroforézis

Sm: $\quad$ sztreptomicin

SOB: $\quad$ super optimal broth (tápanyagokban gazdag tápoldat)

SQR: $\quad$ szulfid kinon oxidoredukáz

Tc: $\quad$ tetraciklin

TEMED: $\quad$ N,N,N',N'-tetrametil-etilén-1,2-diamin

TRIS: $\quad$ Trisz-(hidroximetil)-aminometán

U: $\quad$ egység (unit)

UC: $\quad$ ultracentrifuga 


\section{Bevezetés}

A kén minden sejt számára esszenciális elem. Szerves vagy szervetlen vegyületei gáz, folyadék és szilárd halmazállapotban is előfordulnak a természetben. Legredukáltabb formája a szulfid, mely az élet kialakulásának teret biztosító „ősleves” fontos alkotórésze volt. Az élőlények számára bizonyos koncentráció felett toxikus azáltal, hogy a légzési láncot gátolja. Azonban ismert toxicitása ellenére számos fiziológiai funkciót lát el mind prokarióták, mind eukarióták életében. Emlősöknél fontos szerepet tölt be a központi idegrendszerben, kardiovaszkuláris rendszerben, angiogenezisben, izomtónus szabályozásában. Prokarióták esetén elektrondonorként szolgál számos fotoftróf mikroorganizmusnak. A szulfid detoxifikálásában, homeosztázisának fenntartásában, illetve elektrondonorként való felhasználásában a szulfid oxidáló enzimek vesznek részt. Ilyen enzimek a flavocitokróm c szulfid dehidrogenáz (FCSD), valamint a szulfid kinon oxidoredukázok (SQR). Ezek az ősi diszulfid oxidoreduktáz fehérje család flavoproteinjei, melyek fontosságát bizonyítja széleskörü elterjedésük. Az SQR fehérjék a növények kivételével az élővilág minden fejlődési ágán megtalálhatóak, azonban diverzitásuk ellenére szerkezetüket tekintve nagyon konzervált enzimek. Az SQR enzimek csoportosítása filogenetikai kapcsolatuk, konzervált szekvencia motívumok és aminosavak meglétén vagy hiányán alapul, mely szerint 6 típust lehet elkülöníteni. Közös jellemzőjük az aktív centrumban található FAD kofaktor, továbbá a katalízisben eszenciális ciszteinek, melyek az enzimcsoportok között eltérhetnek. Az enzim müködése folyamán a szulfid oxidáció során keletkező elektronokat a membrán kinonraktárába juttatja. Az SQR típusú fehérjék szerkezetéről, müködési mechanizmusáról kevés adat áll rendelkezésünkre. A legrészletesebben jellemzett csoport az I. típus. A VI. csoport tagjai közül csak egy enzimet vizsgáltak részlegesen, míg a IV. nem rendelkezik jellemzett képviselővel. Számos esetben előfordul, hogy egy mikroorganizmus több, különböző csoportba tartozó SQR enzimmel rendelkezik. Tehát a szulfid kinon oxidoreduktáz fehérjék fontosságából adódóan minél több információ szükséges ezen enzimek széles körü biokémiai megismeréséhez, működésük megértéséhez, funkciójuk feltárásához. 


\subsection{Szulfid előfordulása a természetben}

A kén az élóvilág 6. leggyakoribb eleme, minden sejt számára eszenciális, hisz aminosavak (metionin, cisztein), vitaminok (B1 vitamin) és koenzimek (biotin, koenzim A) nélkülözhetetlen alkotórésze. A kén több oxidációs állapotban, szerves vagy szervetlen, szilárd, folyadék és gáz formában is előfordul. Legredukáltabb formája a szulfid $\left(\mathrm{S}^{2-}\right)$, melyet az ösóceánok, egyéb redukált szervetlen vegyületek mellett, nagymennyiségben tartalmaztak. A szulfid nagy mennyiségben fordul elő a természetben, elsősorban vulkáni tevékenységek következtében illetve mélytengeri hidrotermális kürtők környezetében. Továbbá keletkezhet biológiai forrásból: kénvegyületek bontásából aerob és anaerob könyezetben is. Eukarióta sejten belüli képződése L-ciszeinből kiindulva legalább négyféle módon következhet be [1]. $\mathrm{S}^{2-}$ keletkezhet a májban D-ciszteinböl [2]; a citoszol sejtfrakcióban a cisztation- $\beta$-szintáz és cisztation- $\gamma$-liáz közremüködésével a cisztein lebontási folyamata során [3], a mitokondriumban a cisztein aminotranszferáz és 3-merkaptopiruvát szulfur-transzferáz által katalizált reakciósorozatban [4], illetve a bélcsatornában anaerob szulfát redukáló baktériumok által [5].

\subsection{Szulfid szerepe az élővilágban}

Az erősen reaktív szulfid minden élőlény számára egy bizonyos koncentráció felett toxikussá válik elsősorban azért, mert gátolja a légzési lánc IV. komplexét [6]. Ismert toxicitása ellenére alacsonyabb koncentrációban számos funkciót lát el. Elektronokat szolgáltathat a mitokondriális elektrontranszportlánc II. komplexének, mely eredményeként ATP szintézis következik be [7]. Továbbá szerepe van a simaizom tónus szabályozásában [8], a vérnyomás megtartásában [9], központi idegrendszerben és angiogenezisben is [10]. Összefüggéseket fedeztek fel a szulfid-háztartás károsodása és neurodegeneratív betegségek - Down- és Alzheimer szindróma - között [11]. Ezen felül az exogén szulfid elektonforrásként szolgálhat néhány eukarióta (például az Arenicola marina [12], Geukensia demissa [13], Solemya reidi [14], Riftia pachyptila [15]) valamint számos foto- és kemolitotróf baktérium számára. 


\subsection{Szulfid felhasználó mikroorganizmusok}

A szulfidot számos prokarióta képes felhasználni elektronforrásként (1. ábra). Ilyen anyagcsere útvonallal rendelkező törzseket írtak le az Archeae-n belül a Sulfolobales rendből [16]. A további mikroorganizmusok a Baktérium doménbe tartoznak, melyeket aerob litotróf és anaerob fototróf csoportra lehet osztani. Kivételt képez a nem-fototróf obligát anaerob Wolinella succinogenes, mely a szulfid oxidációját a fumarát-légzés közben végzi [17].

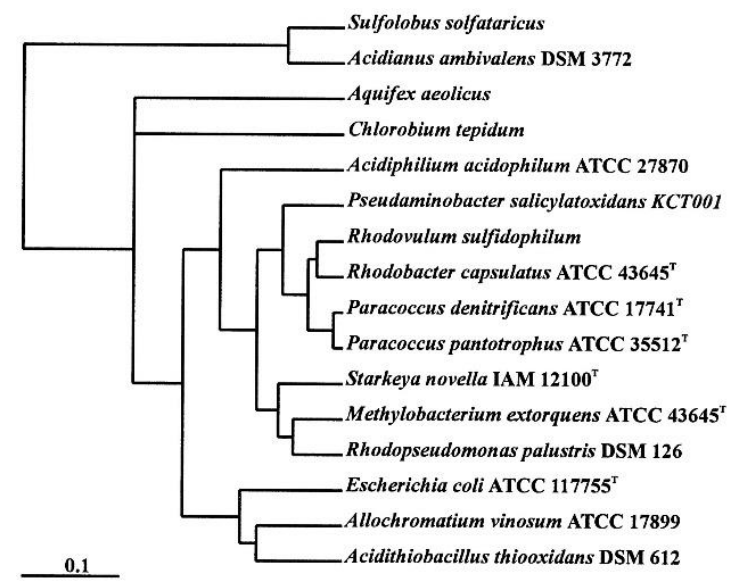

1. ábra: Különböző szulfid oxidáló baktériumok $16 \mathrm{~S}$ rDNS alapján felállított filogenetikai fája [18]

Aerob szulfid oxidáló prokariótákat azonosítottak az Acidianus [19], Acidithiobacillus [20], Aquaspirillum, Aquifex [21], Bacillus [22], Beggiatoa [23], Methylobacterium [24,25], Paracoccus, Pseudomonas [21], Starkeya [26], Thermithiobacillus [20], Thiobacillus, Xanthobacter fajok között [18].

Anaerob fototróf szulfid oxidáló fajokat találunk többek közt az Allochromatium [27], Chlorobium, Rhodobacter, Rhodospeudomonas, Rhodovulum és Thiocapsa [28] génuszokban. Érdekes tény, hogy a bíbor kénbaktériumok közé tartozó Thiocapsa roseopersicina és közeli rokona az Allochromatium vinosum, továbbá bíbor nemkénbaktérium Rhodovulum sulfidophilum [29], és Rhodopseudomonas acidophila [30,31] fajok sötétben is képesek élni litoautotróf módon, mely alapján feltételezhető, hogy a szulfid oxidáció biokémiai mechanizmusa kapcsolt a lito-/ fototróf baktériumoknál [18]. 


\subsection{Szulfid oxidáló enzimek}

A szulfid detoxifikálása, mennyiségének szabályozása, homeosztázisának fenntartása, illetve elektrondonorként való felhasználása a szulfid oxidáción keresztül valósul meg. Ezt a folyamatot a szulfid oxidáló enzimek katalizálják, melyek jelentőségét bizonyítja, hogy széles körben elterjedtek, és feltételezhetően az ősi élet kialakulása óta jelen vannak az élőlényekben. Szulfid oxidáló fehérjék közé tartoznak a flavocitokróm c (Fcc) [32-35] és szulfid kinon oxidoreduktáz (SQR) [36] típusú enzimek. Közös jellemzőjük, hogy az ősi diszulfid oxidoreduktáz (DiSR) enzimcsaládba tartozó FAD-tartalmú fehérjék. Ezek a szulfid oxidációt katalizáló fehérjék megtalálhatóak például Archaea-ban, baktériumokban, gombákban, ízeltlábúakban, illetve az emberekben is [37].

A flavocitokróm c egy nagyobb (FccB) szulfid-kötő, flavin csoportot tartalmazó, illetve egy kisebb (FccA) egy vagy két hem csoportot kötő citokróm c típusú fehérjéből felépülö periplazmatikus enzim (2. ábra) [32].

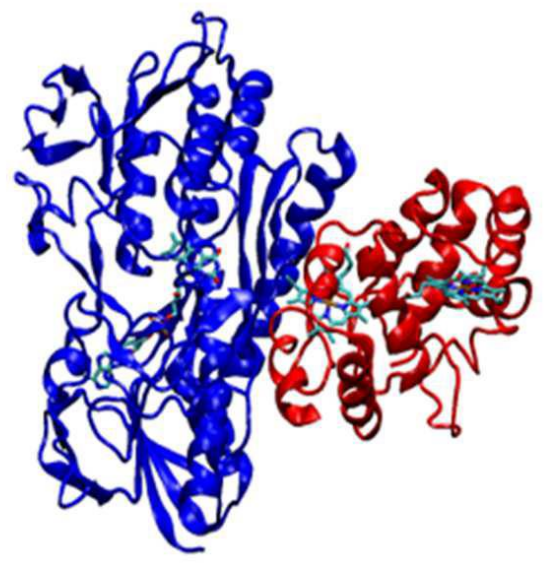

2. ábra: Allochromatium vinosum flavocitokróm c FAD tartalmú nagy alegység (kék) és hem kofaktort tartalmazó kis alegység (piros) térszerkezete [38]

A szulfid oxidációja révén felszabaduló elektronok az FccA által kötött periplazmatikus c-típusú citokróm molekulákra kerülnek, majd a redukált citokróm c-ről az elektronok a fotoszintetikus reakciócentrumon keresztül a membrán kinonkészletébe jutnak. A további lépések kétféle módon mehetnek végbe. A redukált kinon vegyületekről az elektronok a citokróm bc1 komplexen át, proton transzporttal kapcsoltan, visszakerülnek a periplazmában található citokróm c molekulára, ahonnan újra a membránban lévő kinonokra jutnak. Másik lehetőség, hogy a redukált kinonokban tárolt elektronok és a redox 
rendszerek kölcsönhatása által kialakult protongrádiens energiájának felhasználásával, a $\mathrm{NADH}$-dehidrogenáz a $\mathrm{NAD}^{+} / \mathrm{NADH}+\mathrm{H}^{+}$rendszert, ezáltal rekukáló erőt biztosít a sejt számára (3. ábra).

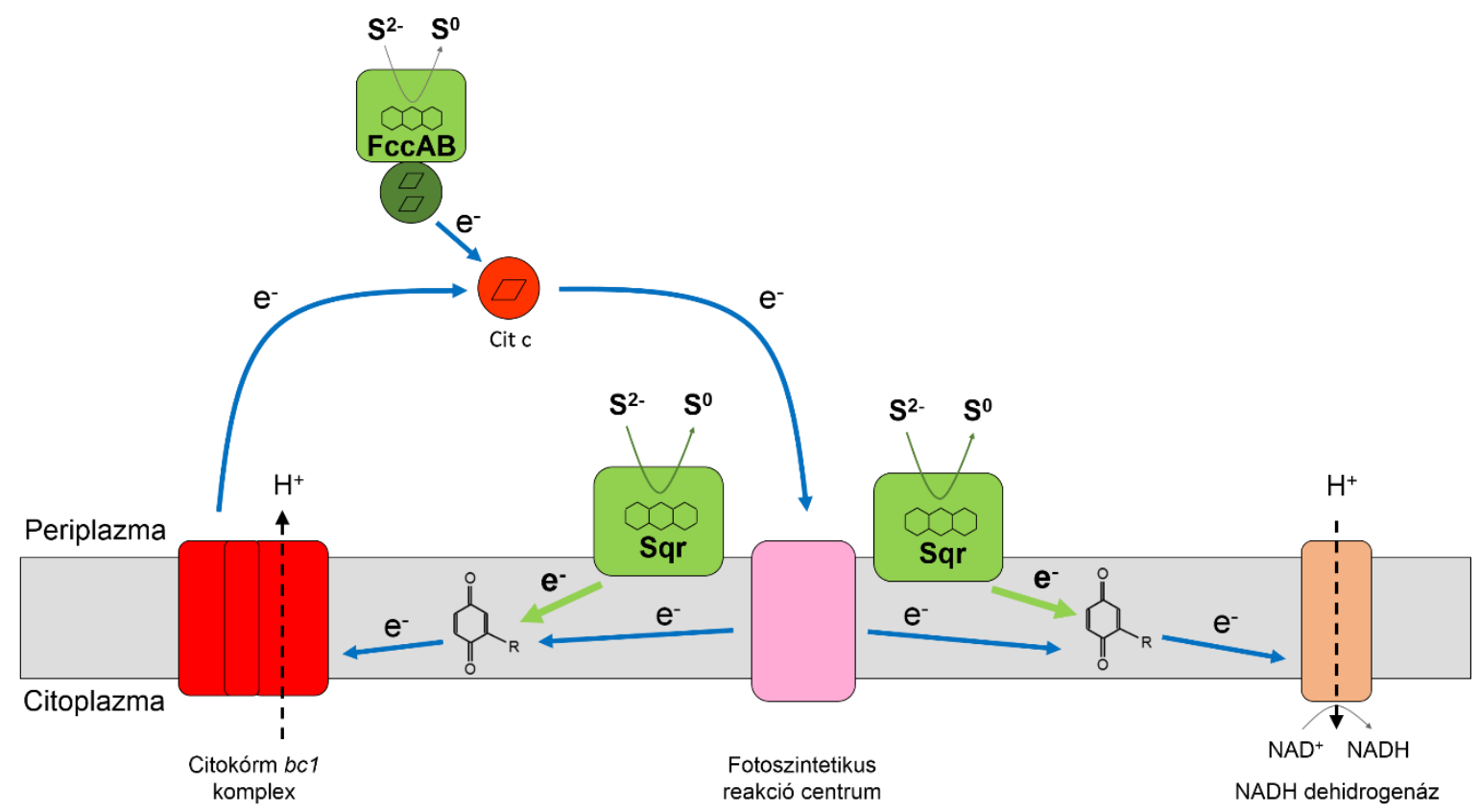

3. ábra: Flavocitokróm c és szulfid kinon oxidoreduktáz szerepe a fotoszintetikus elektrontranszportláncban. Fcc: flavocitokróm c, Sqr: szulfid kinon oxidoreduktáz;

Cit c: c-típusú citokróm

Ezzel ellentétben az SQR fehérjék baktériumokban a periplazmatikus oldalról a sejtmembránhoz, eukariótákban az intermembrán tér felöl a belső mitokondriális membránhoz kötődő, egy alegységes, csak FAD kofaktorral rendelkező monotipikus enzimek. A szulfid oxidációból származó elektronokat, a sejtek számára energetikailag kedvezőbb módon, a FAD-ról közvetlenül egy negatívabb potenciálú elektronakceptorra, a fotoszintetikus vagy plazmamembránban, illetve a mitokondriális membránban található kinonokra jutattja (3. ábra), melyre az Fcc enzim nem képes.

A periplazmatikus és extracelluláris bakteriális fehérjék citoplazmatikus membránon keresztüli átjutására két ismert út létezik: a Sec-függő illetve -független útvonal [39]. A prokarióták SQR fehérjéi esetében nem találtak semmilyen ismert szignál szekvenciát, ettől függetlenül a fehérje valamilyen módon kijut a periplazmába. Deléciós kísérletekkel 
igazolták, hogy az SQR fehérjék C-terminális régiójuk révén jutnak a membrán periplazmatikus oldalára $[40,41]$.

\subsection{Szulfid kinon oxidoreduktáz (SQR) fehérjék}

Az SQR típusú enzimek fontos szerepet játszanak az elsődleges anaerob fotoszintézisben a cianobaktériumokban [42,43], a zöld kénbaktériumokban [42,44-47] és bíbor kénbaktériumokban [36,40,48,49]. Más mikroorganizmusokban egyéb folyamatokban vesznek részt, például az A. aeolicus-ban a légzésben [50], a tengeri férgekben a szulfid detoxifikálásban [51], míg élesztőben növelik a sejtek nehézfém toleranciáját [52]. Ezen felül az SQR enzimeknek számos fiziológiai és patofiziológiai folyamatokban van szerepük, például magasabb rendủ élőlényekben szabályozzák az endogén szulfid szintet [53-55].

\subsubsection{SQR fehérjék csoportosítása}

Az első csoportosítást Theissen és munkatársai írták le, az eukarióta SQR enzimeket 3 csoportra osztották [56]. Az SQR fehérjékről szóló egyre növekvő információk alapján Pham és munkatársai különböző üledékekből felsokszorozott SQR-szerü szekvenciák alapján 6 altípust különítettek el [57]. További SQR enzim adatok fényében Gregersen és munkatársai strukturális, biokémiai és evolúciós analízisek alapján a prokariótákban található SQR enzimeken belül 6 csoportot alkottak és egy egységes nevezéktant hoztak létre [58]. A jelenleg is érvényben lévő legrészletesebb csoportosítást Marcia és munkatársai publikálták le, melyet az egyre növekvő számú elérhető szekvenciák és a négy meghatározott SQR fehérje struktúra alapján állítottak fel [59]. A típusok elkülönítése során résztesen elemzik a kofaktor atomi környezetét, a szulfid bejutási útvonalát az aktív centrumba, a kinon-kötési folyamatot, továbbá az addig leírt enzimatikus reakció molekuláris mechanizmusait. 


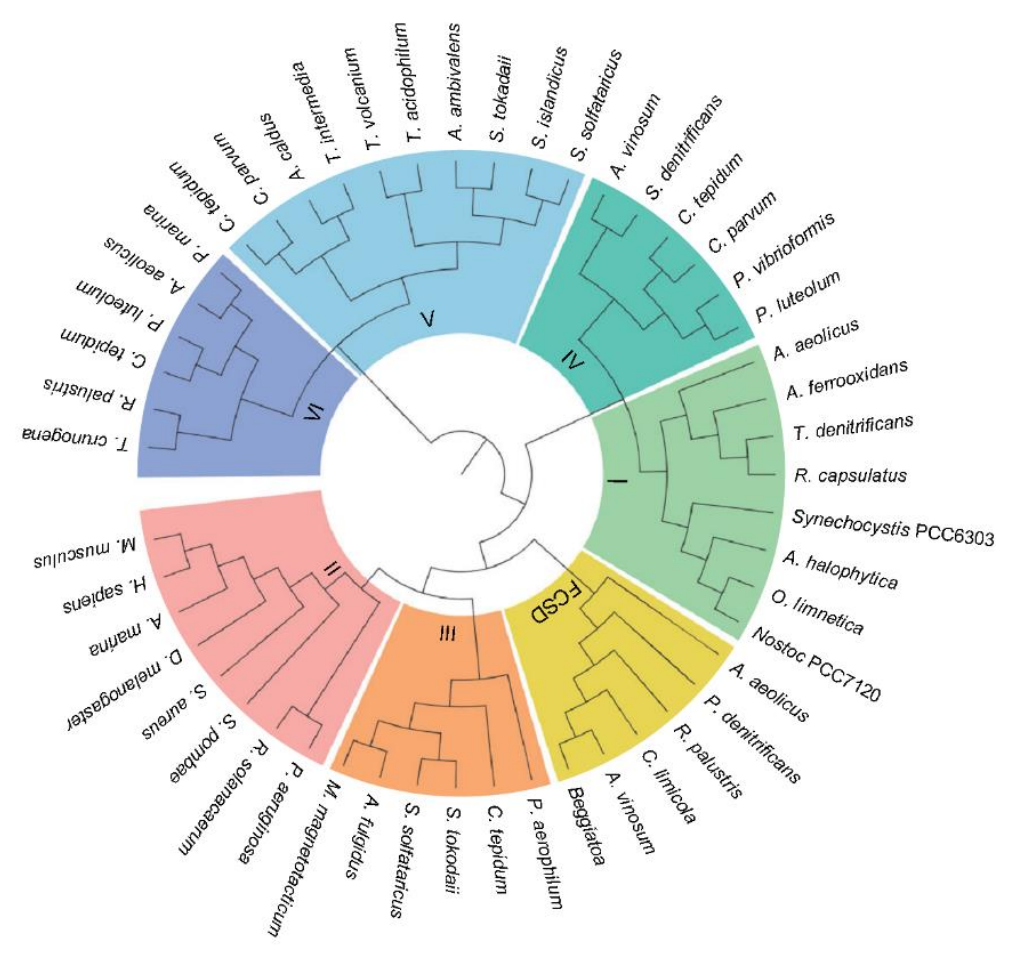

4. ábra: SQR típusú fehérjék filogenetikai csoportosítása [59]

Ezen adatok alapján meghatározott konzervált motívumok és aminosavak megléte illetve hiánya alapján az SQR-típusú fehérjéket 6+1 csoportra osztották, melyek megfeleltethetőek a 6 főbb fejlődési ágnak (5. ábra) [58]. A csoportosítás utolsó típusát a flavocitkróm c szulfid dehidrogenáz (FCSD) nagy alegysége $(\mathrm{FccB})$ alkotja (4. ábra), sokáig ehhez az enzim alegységhez mutatott hasonlóság alapján határozták meg egy fehérjéről, hogy Sqr típusú-e vagy sem. 


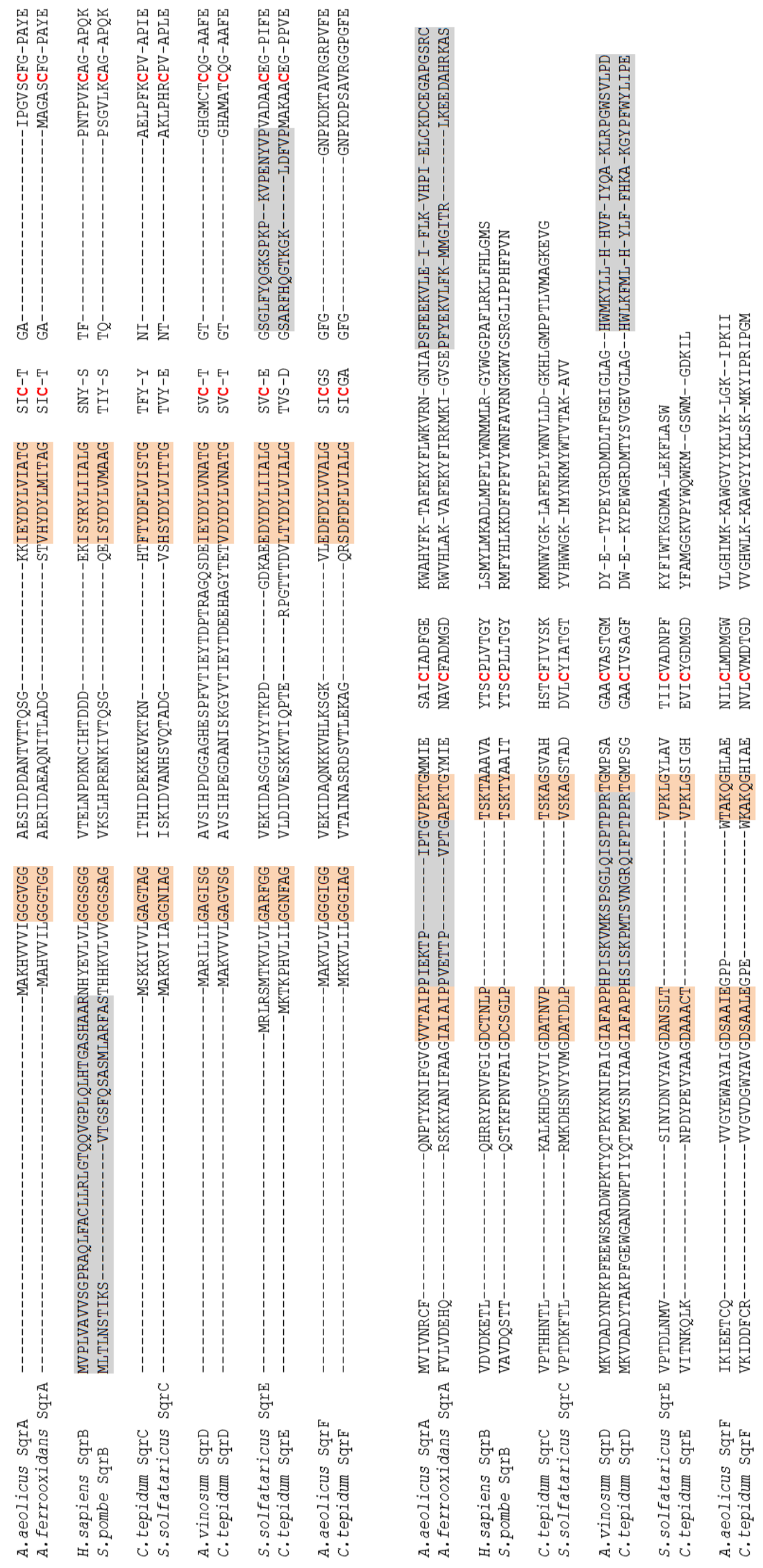

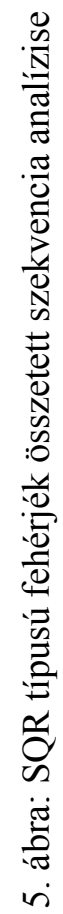




\section{I. típusú SQR fehérjék (SqrA):}

SqrA enzimeket azonosítottak az Aquificaceae, $\alpha$ - és $\beta$-Proeobacteria és Cyanobacteria csoportokban. Vizsgálatok alapján konstitutívan fejeződnek ki, ami fontos a hatékony szulfid detoxifikáláshoz. Emellett szerepük van a szulfid függő légzésben és a fotoszintézisben is [50] [43]. Az I. típusú SQR fehérjék kulcsmotívumai az ún. „sapka” hurkok, továbbá a meghosszabbodott C-terminális régió. A hurkok az egyedüli elektrondonor, a szulfid szelektív bejutását biztosítják a fehérje aktív centrumába. A többi SQR típustól eltérően az SqrA enzimek hosszabb C-terminálissal rendelkeznek, mely régió két amfipatikus $\alpha$-hélixből és egy hurokból áll. Az A. aeolicus SqrA enzim katalízisében fontos aminosavak: C124, mely a FAD kötésében játszik szerepet; a redox-aktív párt alkotó C156 és C347, melyek elengedhetetlenek az enzim müködése szempontjából. További aminosavak: a feltehetően egy szulfid szubsztrát csatorna kialakításában részvevő $\mathrm{S} 155$; V294; P311 és a E162 és K312, melyek a proton donor/akceptorként funkcionálnak a reduktív reakció során. A kinon kötéséért felelös I346 és F385; végül a E318 és K382, melyek a kinon redukció során a protonok cserélődésében játszanak szerepet.

\section{II. típusú SQR fehérje (SqrB):}

SqrB fehérjék széles körben elterjedtek: Firmicutes és Proteobacteria-tól kezdve patogéneken át, eukariótákban - élesztők, férgek, ízeltlábúak, emlősök - is képviseltetik magukat. Nem rendelkeznek ,sapka” vagy meghosszabbodott hurokkal. Az SQR fehérjék között kivételt képez az eukariótákban találhatók N-terminális régiója, amely tartalmaz a szignál szekvenciát. A konzervált ciszteinek közül a FAD-kötésben szerepet játszó ciszteint egy tirozin helyettesíti, további két cisztein itt is megtalálható. A kinon redukcióban fontos aminosavak kevésbé konzerváltak az I. típushoz képest.

\section{III. típusú SQR fehérje (SqrC):}

Zöld kénbaktériumokban és Archaea-ban megtalálható enzimek. Jellemzöjük, hogy „sapka” hurkokkal nem rendelkeznek, továbbá a kofator nem kovalens módon van kötve, mivel a FAD-kötésben fontos cisztein is hiányzik belölük. Ezt a C. maquilingensis SqrC enzimnél kísérletesen is igazolták, amely a csoport egyetlen vizsgált képviselője [41]. 


\section{IV. típusú SQR fehérje (SqrD):}

SqrD fehérjék képviseltetik magukat a zöld és bíbor kénbaktériumok csoportjában. Eddig még egyetlen tagot sem sikerült biokémiailag jellemezni. Szekvenciáját tekintve nagyon karakteres csoport, 5 meghosszabbodott hurokkal rendelkezik, C-terminálisuk hossza megegyezik az I. típusnál leírtakkal. Továbbá a koncervált ciszteinek illetve a szulfid bejutásában szerepet játszó aminosavak is jelen vannak a fehérjékben.

\section{V. típusú SQR fehérje (SqrE):}

Archeális fehérjének nevezik az V. típusú SQR enzimek egy csoportját, mivel a Sulfolobales rendben azonosíthatóak. Szekvenciájukban felismerhető egy „sapka” hurok, továbbá rövid C-terminális régióval rendelkezik. Konzervált ciszteinjei mellett; a kinon kötéséért felelős S214, D215, D353 és a proton cserélődésében fontos aminosavak is megtalálhatóak. A bakteriális SqrE fehérjék különböznek az előzőekben leírtaktól: „sapka” hurkuk rövidebb, a FAD-kötő cisztein helyett szerin vagy treonin található bennük, ezáltal nem képesek kovalens kötést létesíteni a kofaktorral. Emellett a szulfid belépési útvonalban szerepet játszó S214 helyett alaninnal rendelkezik, mely a szulfid nehezebb bejutását eredményezheti.

\section{VI. típusú SQR fehérje (SqrF):}

Bakteriális fehérjék, C. tepidum [44] és A. aeolicus [59] esetén igazolták jelenlétét. Kevésbé ismert csoport, csak egy, részben jellemzett tagja van [60]. Az I. típusú SQR fehérjékben lévő 156. cisztein megfelelője ebben a csoportban valin, izoleucin vagy metionin, viszont a 275. pozícióban lévő cisztein konzervált az SqrF enzimeken belül. Ez a csoport azonban messze van az aktív centrumtól (1. táblázat). 


\begin{tabular}{|c|c|c|c|c|c|c|c|c|c|c|c|c|c|c|c|c|c|c|}
\hline & \multicolumn{18}{|c|}{ Kulcs motívumok és aminosavak } \\
\hline & \multicolumn{13}{|c|}{ Szulfid oxidáció } & \multicolumn{5}{|c|}{ Kinon redukció } \\
\hline & & & & & & & & & & & & & & & & & & Meghosszabbodott \\
\hline SQR tipus & C124 & 1."sapka" hurok & S155 & C156 & E162 & S214 & D215 & D353 & V294 & 2."sapka" hurok & P311 & K312 & C347 & E318 & 31346 & K382 & $\mathrm{F} 385$ & C-terminális \\
\hline I. & c & Nincs & S/G & c & $\mathrm{E}$ & G & $\mathrm{H}$ & D/E & $\mathrm{V} / \mathrm{I}$ & Van & $\mathrm{P}$ & $\mathrm{K}$ & c & $\mathrm{E}$ & VI/L & $\mathrm{K}$ & $\mathrm{F}$ & Van \\
\hline II. & Y & Nincs & $\mathrm{K}$ & c & $\mathrm{K}$ & $\mathrm{F}$ & n.r. & n.r. & D & Nincs & S/A & $\mathrm{K}$ & c & n.r. & n.r. & $\mathrm{K}$ & F/ML & Nincs \\
\hline III. & Y/W & Nincs & $\mathrm{R} / \mathrm{K}$ & C & $E$ & $\mathrm{~F} / \mathrm{H}$ & n.r. & n.r. & D & Nincs & $S / P$ & K & c & $\mathrm{D} / \mathrm{H}$ & n.r. & K & $F / Y$ & Nincs \\
\hline IV. & c & Nincs & T & C & E & G & D & $\mathrm{s}$ & 1 & Van & $\mathrm{P}$ & $\mathrm{K}$ & C & $\mathrm{G} / \mathrm{A}$ & A & K & Y/W & Van \\
\hline V-Archea & C & Van & A & C & $E$ & $s$ & D & D & D & Nincs & $P$ & K & C & v & VII & K & A & Nincs \\
\hline V-Baktérium & $S / T$ & Van & A & C & $E$ & A & $E$ & D & D & Nincs & $P$ & K & c & $\mathrm{H}$ & VI/IY & K & W & Nincs \\
\hline V. & C & Nincs & A & V/M & E & G & n.r. & D & D & Nincs & AVP & K & C & $E / D$ & L/F/V & $\mathrm{K}$ & W/F & Nincs \\
\hline
\end{tabular}

1. táblázat: SQR típusú fehérjék kulcs motívumainak és aminosavainak összefoglaló táblázata (n.r.:nem releváns) [59]

\subsection{2. $\quad s q r$ gének expressziós szabályozása}

Számos mikroorganizmus tartalmaz egy vagy akár több SQR-típusú fehérjét, azonban kevés mikroorganizmusban vizsgálták a fehérjék fiziológiás funkcióját. Kevés adat áll rendelkezésünkre azzal kapcsolatban, hogy hogyan hat az SQR fehérje jelenléte / hiánya a sejtek növekedésére szulfid, mint egyedüli redukált kénforrás mellett. Továbbá, hogyan változik különböző növesztési körülmények között az SQR fehérjéket kódoló gének expressziója, SQR fehérjék mennyisége. Weissberger és munkatársai [61,62] Allochromatium vinosum esetén transzkriptomikai és proteomikai vizsgálatot folytattak a szulfidnak a sejtek anyagcseréjére gyakorolt hatásának érdekében, melyekben néhány adatot közölnek az A. vinosum-ban található IV. és VI. típusú SQR fehérjékről (SqrD és SqrF). Kísérletük során a sejteket egyedüli kénforrásként, $4 \mathrm{mM}$ szulfid mellett növesztették, a proetomikai vizsgálatoknál 8 óráig, transzkriptomikai vizsgálatok során 2 óráig. Ennek az az oka, hogy a transzkriptek szintjén a sejtek várhatóan hamarabb reagálnak az adott körülményre, míg a fehérjék szintjén a környezeti változás hatása később jelenik meg és tovább tarthat. Transzkriptomikai eredményeik alapján az sqrD és az $s q r F$ transzkript szintje nem változott a fentebb említett kísérleti körülmények között. Hasonlóan a gén kifejeződési szintekhez, az SqrD és SqrF fehérjék mennyiségének változása elenyésző volt. Azonban ha a két fehérje közötti mennyiségi változást vizsgáljuk, az SqrD fehérje mennyisége közel kétszerese volt az SqrF fehérjéhez képest [62,63]. Összeségében széleskörüen vizsgálták a sejtekben található metabolitokat, transzkriptomokat, proteomokat, azonban csak egyféle szulfid koncentráció (4 mM) mellett.

Chan és munkatársai egy zöld kénbaktérium, a Chlorobaculum tepidumban található három SQR homológ (CT0117 (SqrD), CT0876 (SqrE), CT1087 (SqrF)) vizsgálatát végezték el, melyben a következő kérdésekre válaszoltak: A C. tepidum-ban azonosított 
SQR homológok közül melyik képes szulfid függő ubikinon redukciót katalizálni, illetve mely homológok jelenléte szükséges a sejtek szulfid, mint egyedüli elektronforrás melletti növesztéséhez. Kísérletük során $C$. tepidum sejteket 9,2 $\mathrm{mM}$ nátrium-tioszufát és $0,7 \mathrm{mM}$ szulfid tartalmú tápoldatban növesztettek, majd különböző időpontokban RNS-t izoláltak. RT-qPCR segítségével megállapították, hogy a CT0117 és CT0876 transzkriptje jelen volt minden vizsgált időpillanatban, azonban a CT1087, csak a korai (14 óráig) mintavételi időpontokban volt detektálható. Egy másik kísérlet során a sejteket 4, 6 és $8 \mathrm{mM}$ szulfid koncentráció mellett növesztették 15 órán keresztül, majd vizsgálták az sqr gének transzkript szintjét, mely során már mindhárom homológ génjének transzkriptje azonosítható volt. Ezek alapján azt a következtetést szürték le, hogy a CT1087 csak addig van jelen a sejtben, amíg a sejt szulfid oxidációt végez, mely előzetes eredmények alapján a $C$. tepidum-nál a $0,7 \mathrm{mM}$ szufid mellett körülbelül 15 óráig tart. Azonban a magasabb szulfid koncentrációjú tápoldatban növesztett sejtek tovább képesek voltak katalizálni a szulfid oxidációt. Vizsgálták továbbá a vad típusú és az SQR homológokban mutáns sejtek növekedését különböző szulfid koncentráció mellett 48 óra inkubációt követően. A vad típusú törzs maximális növekedését 6-8 mM szulfid mellett érte el, melyhez hasonló eredmény volt megfigyelhető a CT0117 és CT0876 mutánsok esetén is. A CT1087 mutáns sejtek viszont már 6 mM szulfid jelenlétében sem voltak képesek nőni, a CT0117 - CT1087 duplamutáns törzs növekedése már 4 mM szulfid mellett megállt. Az eredmények alapján a CT1087 és CT0117 homológok szulfid oxidáló enzimek, hiányukban a sejtek nem képesek hasznosítani a szulfidot [44].

\subsubsection{SQR fehérjék termeltetése és tisztítása}

Az eddig ismert SQR fehérjék termeltetésének módját két csoportra lehet osztani: heterológ és homológ expresszióra. Heterológ T7 polimerázon alapuló termeltetést alkalmaztak az Acidithiobacillus ferrooxidans SqrA [64], Caldivirga maquilingensis SqrC [41] és Rhodobacter capsulatus SqrA [36] fehérjék esetén E. coli-ban. Másik csoportot alkotják az A. aeolicus SqrA [65], A. ambivalens SqrE [66] enzimek, melyek esetében a természetes gazdában termelödött fehérjéket tisztították.

A membránhoz kapcsolódó, de nem transzmembrán SQR fehérjék tisztításának első lépése a fehérje membránból való felszabadítása. Az SQR fehérjék szolubilizálását általában nem-ionos detergens: DDM használatával érték el [65] [41], de találunk példát Thesit detergenssel való fehérje felszabadításra is [36]. A detergensek alkalmazása mellett 
a membránhoz kötődő fehérjék szolubilizálására a kaotróp sók - $\mathrm{NaBr}, \mathrm{NaCl}$ - is képesek lehetnek. Ennek példája a $R$. capsulatus esetén alkalmazott $2 \mathrm{M} \mathrm{NaBr}$ használatával történt SQR fehérje membránból való felszabadítása [45]. A szolubilizált, polihisztidin affinitás peptiddel kiegészített rekombináns $\mathrm{SQR}$ fehérjék tisztítását affinitás kromatográfiával végezték. Számos mikroorganizmusban azonosítottak SQR típusú fehérjéket, azonban a biokémiailag részletesen jellemzett enzimek száma alacsony, ami adódhat a membránhoz kapcsolt fehérje tisztítás nehézsége miatt. A tiszta SQR fehérje előállítása számos lépést tartalmaz, mely kezdődik a termeltetéssel, folytatódik a membrán frakcióból való felszabadítással és különböző kromatográfiás lépések sorozatával, vagy affinitás kromatográfiával végződik. Összeségében kijelenthető, hogy a membránkötött SQR fehérjék termeltetése és tisztítása nehezen kivitelezhető feladat, vélhetően ez az oka a kevés jellemzett SQR képviselőnek.

\subsubsection{SQR fehérjék szerkezete}

Kevés adat áll rendelkezésünkre a szulfid oxidáló enzimek szerkezetével kapcsolatban. Mindössze az A. vinosum flavocitokróm c, A. aeolicus SqrA, A. ferrooxidans SqrA, és A. ambivalens SqrE fehérjék kristályszerkezete ismert.

A

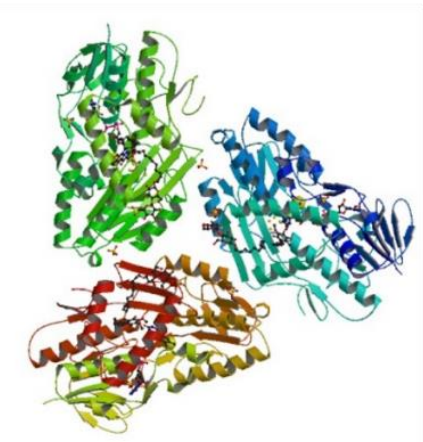

B

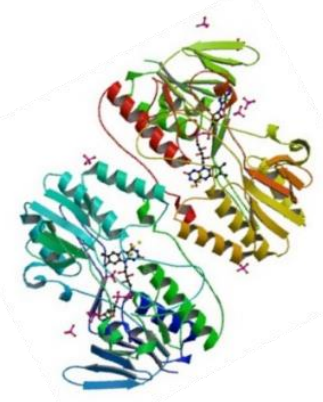

C

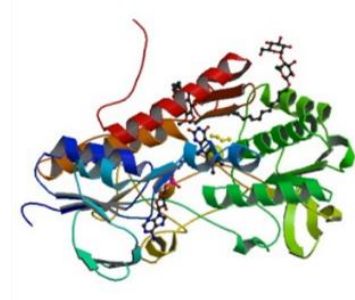

6. ábra: A. aeolicus SqrA [67] (A), A. ferrooxidans SqrA [68] (B) és az A. ambivalens SqrE [66]

(C) fehérje térszerkezete

A 6/A. ábrán látható, hogy az A. aeolicus SqrA fehérje egységei a fehérje kristályrácsaiban trimer formában voltak jelen, mely szerkezetet a fehérje fiziológiás állapotának gondolják [67]. Megállapításukat kísérletesen igazolták: a tisztított SqrA fehérje glutárdialdehid 
kezelés után SDS gélen 3 sávot adott, amelyek mérete megegyezett a monomer, dimer és trimer formák in silico számított méretével [65]. Másik térszerkezettel rendelkező, A. ferrooxidans-ban található I. típusú SQR fehérje dimer formáját azonosították (6/B. ábra), azonban az A. aeolicus SqrA fehérjével szemben, ez az állapot a monomerek egymáshoz viszonyított helyzete alapján feltételezhetően nem felel meg a fiziológiás formának[68]. A V. típusba tartozó A. ambivalens SqrE fehérjét - kristályosítása után - monomer szerkezetben azonosították (6/C. ábra). A fehérje C-terminális régióját nem voltak képesek meghatározni egyértelmüen, mivel a kristály rácspontjaiban lévő fehérjék C-terminálisai különböző térszerkezettel rendelkeztek [66].

\subsubsection{1. $\quad \underline{\text { Az SQR fehérjék FAD kofaktor kötése }}$}

Fontos különbségek figyelhetőek meg az SQR fehérjéken belül a FAD izoalloxazin csoportjának környezetében. Ezen különbségek a kofaktor kovalens vagy nem kovalens kötésének módjában és a FAD kofaktort tartalmazó katalitikus centrum pozíciójában rejlenek. Az I. típusú SQR-eknél általános, hogy a kofaktor és a fehérje közt nincs kovalens kötés, azonban az Fcc-k és az SQR-ek nagyrésze kovalens módon köti a FAD-ot. Ezt az erős kötést általában egy cisztein kénatomja tioéter kötéssel hozza létre a FAD izoalloxazin gyürü C8 metil csoportjával [38,66] vagy mindez egy diszulfid hídon [67] keresztül valósul meg.

Az I. típusú $A$. ferrooxidans SQR fehérje esetén a C128 nem köti a FAD kofaktort [68], ellentétben az A. aeolicus SqrA enzimmel, melynél a 124. cisztein kapcsolatot létesít a FAD izoalloxazin gyürü C8 metil csoportjával. Azonban a köztük lévő távolság miatt ez a kötés csak egy labilis perszulfid híd lehet [59]. A II. és III. típusú SQR fehérjékben nincsen FAD-kötő cisztein, így ezen enzimeknél a kofaktor nem kovalens módon kötött a fehérjén belül, melyet C. maquilingensis SqrC esetén igazoltak [41]. Az A. ambivalens SqrE 129. cisztein kénatomja tioéter kötést alakít ki a kofaktor C8 metil csoportjával [59]. A kialakult kovalens kötést Brito és munkatársai kísérletesen is igazolták, úgy, hogy a triklórecetsavval denaturált fehérje felülúszójában nem volt FAD kofaktor [66].

\subsubsection{2. $\quad$ A szulfid útvonala SQR fehérjékben}

A meglévő SQR típusú fehérje térszerkezetek alapján a „sapka” hurok biztosítja, hogy elektrondonorként csak a szulfid jusson be a fehérje katalitikus centrumába [59]. 
Az A. ambivalens SqrE esetén ezt a hurkot a 154. glicin és 178. cisztein közötti polipeptid szakasz alkotja, mely részben átfed a meghosszabbodott C-terminális régióval. A hasonló funkciót ellátó szerkezeti elem az A. aeolicus SqrA fehérjében a 294. valin és 312. lizin között található, azonban ezen hurok az A. ambivalens SqrE fehérjénél tapasztalt elhelyezkedésével szemben a másik irányba terjed ki. A V294 aminosavat teszik felelőssé a szulfidhoz való affinitásáért [69], míg a lizint a katalitikus folyamat során végbemenő proton cserélődéséért [66]. A fehérje szerkezetek elemzése alapján a szulfid kötésében szerepet játszó alagutat az A. ambivalens SqrE esetén a S176, S214, D215 és D353, míg az A. aeolicus SqrA-nál a S155, P311 és K312 aminosavak alkotják. Érdekes, hogy a szintén I. típusú A. ferrooxidans fehérje esetén viszont a 160. és 356. cisztein mellett a 166. glutaminsav játszik szerepet az alagút kialakulásában. A különbségek alapján elmondható, hogy az SQR fehérjékben a szulfid, mint szubsztrát eltérő mechanizmus során kerül megkötésre.

\subsubsection{3. $\quad$ SQR fehérjék C-terminális régiója}

A hidrofób aminosavakkal teli C-terminális régió nagyon változatos az SQR- típusok között, de minden esetben fontos szerepe van az elektronakceptor kinon szubsztrát és a fehérje kölcsönhatásában. Az A. aeolicus SqrA enzim hosszú C-terminálissal (376-412 aminosav) rendelkezik, mely kettő amfipatikus $\alpha$-hélixet alkot. Ez a régió további 18 aminosavat tartalmaz, mely a feltételezések szerint a trimer forma kialakulását mediálja [59]. A C-terminális vég oligomerizációban betöltött szerepét igazolták az A. ferrooxidans SqrA enzim esetén is. A dimerként kristályosodott formáknál azt tapasztalták, hogy a monomerek a hidrofób C-terminális régión keresztül kapcsolódtak [68] (6./B ábra). Az A. ambivalens SqrE fehérje C-terminálisáról szerkezeti adatok nem állnak rendelkezésre, azonban szekvenciájából látszik, hogy rövidebb, mint az előző két fehérjénél, ezért valószínűleg csak egy $\alpha$-hélix alakul ki rajta [66]. Az enzim nem kristályosodott sem dimer, sem trimer formában (6./C ábra), tehát az SqrE hélixe, úgy tünik, nem szükséges az oligomerizációhoz [59]. A kialakuló negyedleges szerkezet és a katalízis között nem feltételeztek összefüggést, a hélix inkább a fehérje membránban való orientációjában játszhat szerepet [68]. 


\subsubsection{Az SQR enzimek katalitikus működése}

Az SQR enzimek szulfid oxidációt katalizálnak, mely végeredményeként egyenes vagy elágazó láncú poliszulfid vagy 8 kénatomból álló gyürü keletkezik, mely a sejten belül a citoplazmában vagy a periplazmatikus térben raktározódik. A katalitikus folyamat két redox alfolyamatot tartalmaz: első az oxidatív fázis, ahol a szulfid oxidációja során keletkező elektronok a FAD kofaktorra kerülnek, ezt követi a reduktív lépés, mely során az elektronok a FAD kofaktorról a membránban lévő kinonokra jutnak. A katalízisben konzervált ciszteinek játszanak esszenciális szerepet, melyek száma és fehérjén belüli elhelyezkedése a különböző SQR típusokban eltérőek lehetnek [70]. Mindez magában hordozza a változatos katalitikus mechanizmusok lehetőségét. A fehérjék térszerkezete és biokémiai vizsgálatai alapján eddig kevés SQR enzim müködési mechanizmusát írták le. A modellek közös tulajdonsága, hogy a reakcióhoz nélkülözhetetlen 2 vagy 3 cisztein (reaktív párt alkotó két cisztein és a FAD- kötő cisztein) és a közöttük kialakuló diszulfid híd. 

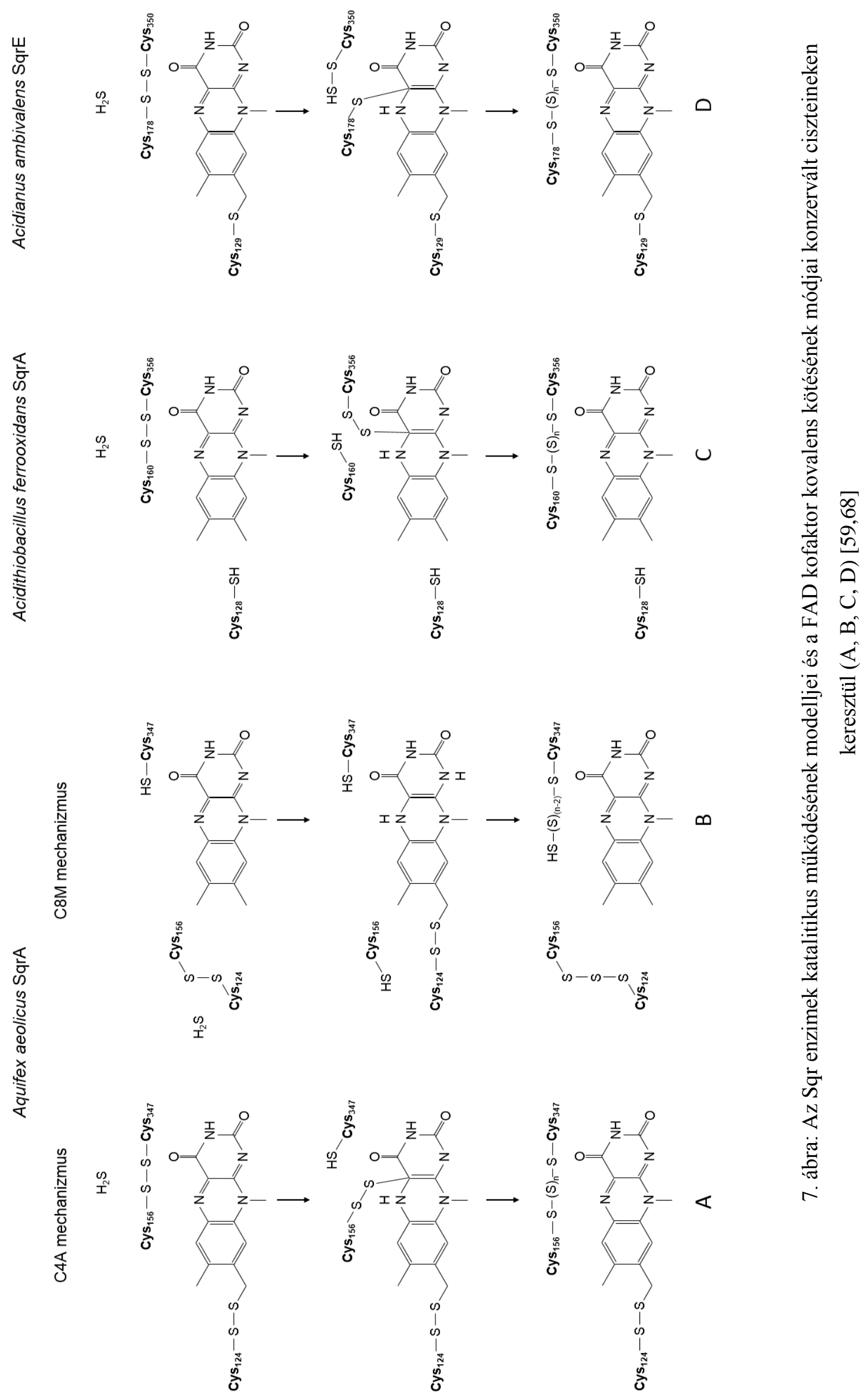
Az SqrA fehérjék esetén három lehetséges katalitikus mechanizmust írtak le (7. ábra). A. aeolicus-ban található I. típusú SQR enzim müködéséről kétféle modellt is feltételeznek. A C4A modell esetében a C156 és C347 aminosavak alkotják a reaktív cisztein párt. A köztük lévő diszulfid hidat bontja fel a szulfid, majd a 156. cisztein beköt a FAD C4A csoportjához, mely során elektronokat ad át, majd visszacsatol a C347 aminosavra, melyen épül a poliszulfid lánc (7/A. ábra). Hasonló mechanizmust feltételeznek az A. ambivalens SqrE enzim esetén (7/D. ábra), azonban itt a végtermék egy 8 kénatomból álló gyürü, mely a szerkezeti vizsgálat alapján a citoplazmatikus térben halmozódik fel [67]. Más mikroorganizmusoknál ismert, hogy a kialakuló kéngyürüt a periplazmában tárolják [48]. Az A. aeolicus SqrA enzimének müködésére leírt C8A modell szerint viszont a 124. és 156. pozícióban lévő ciszteinek kapcsolódnak diszulfid híddal egymáshoz. A szulfid belépésének következményeként a C124 perszulfid híddal kapcsolódik a FAD C8M atomjához.A kialakult kötés egyik kénje az 124. ciszteinhez tartozik, míg a másik a szubsztrátból származik. Miután megtörtént az elektrontranszfer a kialakult komplexben a C156 támadja a perszulfid hidat, ezáltal létrehozva egy triszulfid hidat (8/B. ábra). Az összes SQR típusban konzervált cisztein, jelen esetben a C347 feladata a 156. cisztein következő ciklusra való felkészítésben továbbá a képződő 8 atomos kéngyürü képződésében lehet $[59,67]$.

Az A. ambivalens SqrE enzim müködési mechanizmusa (C4A mechanizmus) alapján a reaktív 178. és a 350. ciszteinek diszulfid híddal kapcsolódnak. Ezt a diszulfid hidat támadja meg a szulfid szubsztrát, aminek hatására egy perszulfid híd jön létre a C350 kénatomja és a szulfid egyik kénatomja között, továbbá a C178 aminosavon egy tiolát anion. A kialakult tiolát anion támadja az elektronhiányos FAD C4A atomját, mely során két elektront juttat át a FAD-ra. Ezután képes visszakapcsolni a C350 kén atomjaihoz, ahol a poliszulfid lánc épül, mely lehet egyenes vagy elágazó láncú [66] (7/D. ábra).

Az A. ferrooxidans SqrA esetén C4A mechanizmust írtak le, mely szerint a reaktív cisztein pár a diszulfid híddal kapcsolódó C160 és C356 aminosavakból áll. A szulfid bejutását követően a 160. ciszteinen egy tiol csoport, míg a 356. ciszteinen diszulfid híd alakul ki, mely kapcsolódik a FAD C4A atomjához. A FAD izoalloxazin gyürüvel való kapcsolat során a kofaktorra elektronok és protonok jutnak át. A következő lépésben a 160. cisztein a C356-C4A közötti kötést támadja kialakítva egy triszulfid hidat a C160 és C356 között. A képződő poliszulfid lánc a 160. ciszteinen épül, majd miután az ismétlődő 
reakcióciklusok során kialakult a 8 kénatomos gyürü a C128 kapcsolódik a C160 aminosavhoz, melyről így leválik az oxidált kéntermék [68] (7/C. ábra).

\subsection{Fotoszintetikus baktériumok}

A fototróf prokarióták legfontosabb közös tulajdonsága, hogy fotoszintetikus apparátusuk segítségével a fényenergiát képesek a növekedésükhöz felhasználni. Azonban számos fiziológiás különbséggel rendelkeznek. A cianobaktériumok elektrondonorként vizet használnak, melynek bontásával molekuláris oxigént állítanak elő. A másik nagy csoportba az anaerob fotoszintézist folytató baktériumok tartoznak: ilyenek a bíbor és a zöld baktériumok, valamint a heliobaktériumok. Ezen mikororganizmusok anaerob fotoszintézisük során elektrondonorként redukált kénvegyületeket és/vagy szerves anyagokat használnak.

\subsubsection{Fototróf kénbaktériumok}

Fototróf kénbaktériumként ismert csoportok a bíbor kénbaktériumok és a zöld kénbaktériumok, amelyek képesek a redukált kénvegyületeket, például szulfidot elektrondonorként hasznosítani. A zöld kénbaktériumok közé tartozik a Chlorobiaceae család, míg a bíbor kénbaktériumokhoz a Chromatiaceae és Ectothiorhodospiraceae család.

\subsubsection{Bíbor kénbaktériumok}

A bíbor kénbaktériumok filogenetikailag a gamma-proteobaktériumokhoz tartoznak, melynek fajai édes és tengervízben egyaránt megtalálhatóak. A fotoszintetikus bíbor kénbaktériumok növekedésük során elektronforrásként redukált szervetlen kénvegyületeket például szulfidot és/vagy tioszulfátot hasznosítanak. Fontosabb tulajdonságaik, hogy bakterioklorofill a-t és b-t tartalmaznak és II típusú reakciócentrummal rendelkeznek, továbbá a szén-dioxid fixálást a Calvin ciklus során végzik.

A Chromatiaceae család tagjait két típusra lehet osztani: első csoportba a speciális metabolizmussal rendelkezőket sorolják, a másik csoport képviselői változatos anyagcserét folytatnak. Az utóbbiba tartozik a részletesen jellemzett $A$. vinosum, mely képes tioszulfátot, szulfidot továbbá elemi ként felhasználni elektrondonorként [71]. A csoport tagjai redukált kénvegyületek hiányában heterotróf anyagcserét végeznek, míg jelenlétében kemolitotróf 
módon növekednek [72-74]. Néhány faj kemoorganotróf metabolizmussal rendelkezik, a kénforrás, mint a szulfid vagy a tioszulfát esszenciális, mivel a szulfát asszimiláció gátolt aerob körülmények között [74].

\subsubsection{Fotoszintetikus bíbor kénbaktériumok szulfid anyagcseréje}

Az ide tartozó baktériumok fényfüggő ciklikus elektronáramlás során, a fotoszintetikus reakciócentrumnak illetve a citokróm bc1 komplexnek köszönhetően, a fényenergiát elektrokémiai grádienssé alakítják. Az így kapott energiát többek közt a $\mathrm{NAD}^{+} \mathrm{NADH}-$ ra történő redukálására használja fel a sejt, majd a redukáló erő nagyrészt a szén-dioxid fixálására fordítódik. A fotoszintetikus bíbor kénbaktériumok növekedésük során redukált szervetlen kénvegyületeket (például szulfidot) képesek elektronforrásként felhasználni. A szulfid oxidációban szerepet játszó enzimek a flavocitokróm c szulfid dehidrogenáz (FCSD) [71], illetve a szulfid kinon oxidoreduktáz (SQR) [36]. A Chromatiaceae családba tartozó anaerob fototróf bíbor kénbaktérium, az A. vinosum a Thiocapsa roseopersicina közeli ismert rokona - összetett kénanyagcserével rendelkezik. Növekedéséhez membránkötött szulfid kinon oxidoreduktázai segítségével szulfidot is képes hasznosítani. Genomjában egy IV. és egy VI. típusú SQR enzimet kódoló gént azonosítottak, melyek a legkevésbé ismert SQR csoportok tagjai.

\subsubsection{Thiocapsa roseopersicina BBS}

Doktori kutatásom modellorganizmusa a Thiocapsa roseopersicina, a Chromatiaceae családba tartozó Gram-negatív fotoszintetizáló bíbor kénbaktérium [75]. Az Északi-tengerben található Fríz-szigetek védett öbleinek alsóbb vízrétegéből izolálták. Jól türi a változó oxigén és kén mennyiséget, a különböző kénvegyület összetételt, továbbá a hömérséklet ingadozásokat [76]. Laboratóriumban növeszthető, 25-28 ${ }^{\circ} \mathrm{C}$-on tápfolyadékban 4-5 nap alatt, lemezen közel 14 nap alatt nö fel. Fotoszintetikus pigmentjei miatt rózsaszín színü, melynek árnyalata függ a tápoldat minőségétől illetve a törzs genotípusától. Kultúráinak opálos jellege a sejtek periplazmájában raktározódó kénglobulusokból ered. Anaerob fotoszintetizáló baktérium, fotoszintézise során redukált kénvegyületeket hasznosít elektrondonorként [76,77]. Fotoszintetikus apparátusából hiányzik az oxigént termelö, vízbontó komplex (PSII), így növekedése során nem termel molekuláris oxigént. Oxigén jelenlétében heterotróf anyagcserét folytat. 
Az összetett kénanyagcserével rendelkezö $T$. roseopersicina elektrondonorként képes tioszulfátot, elemi ként, szulfidot is felhasználni. A tioszulfát teljes oxidációjáért egy speciális metabolikus útvonal, a Sox ciklus felelős. A fototróf bíbor kénbaktériumokban a tioszulfátot a sejtek szulfáttá illetve elemi kénné alakítják és ezért a Sox rendszer egy módosult változata felelős [78]. A tioszulfát oxidációját katalizáló enzimek génjei a T. roseopersicina BBS genomban is megtalálhatóak (nem közölt adat). A keletkezett elemi kén kénglobulusban tárolódik a periplazmatikus térben. A kén oxidációjában a disszimilációs típusú szulfit-reduktáz (Dsr) kiemelkedő szerepet tölt be. Ezen enzimek génjeit $T$. roseoperscina-ban szintén azonosították [79]. A kén redukciójából létrejött szulfidot pedig a Dsr rendszeren kívül, szulfid oxidáló enzimek: a flavocitokróm c szulfid dehidrogenáz illetve a szulfid kinon oxidoreduktáz képes továbbalakítani. 


\section{Célkitüzések}

Doktori munkám során célom volt az ösi, konzervált szulfid kinon oxidoreduktáz fehérjék egy eddig még nem jellemzett típusát képviselő enzim részletes funkcionális, strukturális és biokémiai megismerése. Az SQR típusú fehérjék széles körben elterjedtek, számos élettani folyamatban vesznek részt, mind eukariótákban, mind prokariótákban, többek között fototróf kénbaktériumokban. Müködésük részletes megismerése elengedhetetlen az SQR fehérjék által mediált anyagcsere és fiziológiás folyamatok átfogóbb és mélyebb megértéséhez.

Munkám során célul tüztem ki a $\underline{\text { T. roseopersicina genomjában }}$ SQR fehérjéket kódoló gének azonosítását, ésfilogenetikai besorolását. További célom volt, hogy:

felderítsem az SQR fehérjék fiziológiai és kénanyagcserében betöltött szerepüket, melyhez az adott génekben mutáns $T$. roseopersicina törzseket kell elöállítanom.

meghatározzam a szulfid kinon oxidoreduktáz fehérjék spektrális tulajdonságait és kofaktor tartalmát, az enzimek által katalizált reakciót és kinetikai paramétereit, amelyhez tiszta formában van szükségem a fehérjékre. Ehhez expresszáltatnom kell a fehérjéket rekombináns (StrepII affinitás peptiddel fúzionáltatott) formában E. coli vagy T. roseopersicina törzsekben. Továbbá ki kell dolgoznom a membrán fehérjék tisztítására alkalmas metódust, majd a fehérjéket affinitás kromatográfiával tisztítanom.

megértsem az enzim katalitikus müködését, melyhez elsősorban adott aminosavakban mutáns enzimeket termelő törzsek elöállítására van szükség. Ezenfelül az enzim variánsok biofizikai, biokémiai jellemzése mellett, szerepük feltérképezésére szulfhidril csoportokhoz irreverzibilisen kötődő gátlószerek hatásának meghatározását tervezem.

- végül az enzimek jellemzéséből kapott adatok alapján felállítsak egy katalitikus mechanizmus modellt a VI. típusú szulfid kinon oxidoreduktázok müködésének leírására. 


\section{Anyagok és módszerek}

\subsection{Baktériumok tenyésztése}

\subsubsection{E. coli törzsek tenyésztési körülményei}

Az E. coli törzseket LB tápoldatban, Erlenmeyer lombikban, rázatva, a kísérletnek megfelelő hőmérsékleten $\left(4 ; 15 ; 20 ; 37^{\circ} \mathrm{C}\right)$, termosztátban illetve LB agar lemezen (LB tápoldat $+1,5 \%$ agar) növesztettem [80]. A tápoldatoknál az ampicillint $100 \mu \mathrm{g} / \mu \mathrm{L}$, a kanamicint $25 \mu \mathrm{g} / \mu \mathrm{L}$ koncentrációban alkalmaztam.

\subsubsection{T. roseopersicina törzsek tenyésztési körülményei}

A T. roseopersicina törzseket PC tápoldatban, csiszolt dugós Erlenmeyer lombikban vagy táplemezen, anaerob környezetben, hagyományos izzószálas Tungsram (60W) izzóval történő folyamatos megvilágítás mellett, $25-28^{\circ} \mathrm{C}-o s$ hőmérsékleten, 4-5 napig növesztettem.

A tápoldatoknál az antibiotikumokat (streptomicin, gentamicin, kanamicin) $25 \mu \mathrm{g} / \mu \mathrm{L}$ koncentrációban alkalmaztam.

\subsection{RNS-el végzett munkák}

\subsubsection{RNS izolálás}

Az RNS izoláláshoz a $T$. roseopersicina sejteket $2 \mathrm{~g} / \mathrm{L}$ nátrium-tioszulfát tartalmú Pfennig tápoldatban megvilágítás mellett 2 napig neveltem. A tápoldatot lecseréltem nátrium-tioszulfát- és karbonát-mentes tápoldatra anaerob körülmények között. A különböző koncentrációjú nátrium-szulfid hozzáadását követően a kultúrákat $25^{\circ} \mathrm{C}$-on sötétben inkubáltam. $5 \mathrm{~mL}$ kultúra sejtjeit összegyüjtöttem centrifugálással (16800xg, 1 perc). A keletkezett üledéket $300 \mu \mathrm{L}$ SET pufferrel szuszpendáltam fel, majd hozzáadtam $300 \mu \mathrm{L}$ SDS puffert. Az elegyet 1,5 mL-es mikrocentrifugacsőben óvatos fel-le forgatással homogenizáltam, majd $500 \mu \mathrm{L}$ telített $\mathrm{NaCl}$ oldatot adtam hozzá. A sejttörmelékek eltávolítása érdekében a mintát centrifugáltam (16800xg, 10 perc) a tiszta felülúszót átpipettáztam egy új mikrocentrifugacsőbe. A felülúszóban lévő RNS-t a felülúszó térfogat 
70\%-ának megfelelő mennyiségü izopropanollal csaptam ki, majd a mintát centrifugáltam (16800xg, 20 perc). A keletkezett RNS csapadék 1 mL 70\%-os alkoholos mosását követően, centrifugálással (16800xg, 2 perc) és szárítással kapott RNS-t $20 \mu \mathrm{L}$ vízben (DEPC kezelt) vettem fel. Az RNS minta koncentrációját NanoDrop ${ }^{\mathrm{TM}} 1000$ Spektrofotométer (Thermo Scientific) segítségével határoztam meg a minta abszorbancia értéke alapján.

\subsubsection{DNáz I kezelés}

Az RNS mintában lévő DNS szennyeződések eltávolítása érdekében az RNS mintákat $\mathrm{MgCl}_{2}$-ot tartalmazó DNase I Reakció Puffer (10X) és $1 \mathrm{U} / \mu \mathrm{L}$ DNase I (RNasefree) (Fermentas), jelenlétében 30 percig inkubáltam $37^{\circ} \mathrm{C}$-on. A reakció leállítása $50 \mathrm{mM}$ EDTA (Thermo Scientific) jelenlétében $65^{\circ} \mathrm{C}$-os, 10 percig tartó hőkezeléssel történt.

\subsubsection{Reverz Transzkripció}

A reverz transzkripcióhoz az MMLV Reverse Transcriptase (Promega) enzimet használtam a gyártó cég útmutatásainak megfelelően: $1 \mu \mathrm{g}$ DNáz I kezelt totál RNS-t használva templátként. Az RNS-t 0,25 $\mu \mathrm{g}$ specifikus primer (osqrrt2, osqnrt2) (ld. 11.1.6.os függelék) (Fermentas) jelenlétében, $15 \mu \mathrm{L}$ végtérfogatra kiegészítve $70{ }^{\circ} \mathrm{C}$-on inkubáltam 5 percig, majd jégen lehütöttem. Ezt követően $8 \mathrm{mM}$ végkoncentrációnak megfelelő dNTPt, valamint $5 \mu \mathrm{L}$ 5xMMLV (Promega) puffert adtam az elegyhez. A reakcióelegyet $200 \mathrm{U}$ MMLV reverz transzkriptáz (Promega) mellett inkubáltam $42{ }^{\circ} \mathrm{C}$-on 1 órán át.

\subsubsection{Kvantitatív real-time PCR}

A kvantitatív PCR során templátként a reverz transzkripcióban keletkezett cDNS szolgált. A felsokszorozni kívánt fragmentek (70-80 bp) kezdeti és végpontját az sqrD génre specifikus osqrrt1 és osqrrt2 illetve az sqrF génre specifikus osqnrt1 és osqnrt2 oligonukleotidok jelölték ki (ld. 11.1.6.-os függelék). Az abszolút kvantifikációhoz a gének PCR termékeinek tízes léptékü hígítási sorozatával $(0,0001-100$ ng/ $\mu \mathrm{L})$ kalibrációs egyenest készítettem. A $25 \mu \mathrm{L}$ végtérfogatú reakcióelegy összetétele: $12,5 \mu \mathrm{L}$ 2x Power SYBR Green PCR Master Mix (Applied Biosystems), $1 \mu \mathrm{L}$ cDNS, $2 \mu \mathrm{L} 1 \mathrm{pM}$ forward és reverz primer, $9 \mu \mathrm{L}$ nukleázmentes víz. A termékek fluoreszcencia intenzitását Applied Biosystems (Foster City, CA, USA) 7500 Real-Time System PCR készülékkel követtem nyomon. Alkalmazott 
program: 10 perc $95^{\circ} \mathrm{C}, 15$ másodperc $95^{\circ} \mathrm{C}$ és 1 perc $60{ }^{\circ} \mathrm{C} 40$ cikluson át; az olvadási pont meghatározásához pedig: 15 másodperc $95^{\circ} \mathrm{C}, 1$ perc $60^{\circ} \mathrm{C}, 15$ másodperc $95^{\circ} \mathrm{C}, 15$ másodperc $60^{\circ} \mathrm{C}$.

\subsection{DNS módosítási munkák}

\subsubsection{Plazmid DNS izolálás E. coli-ból}

A plazmid DNS izolálás $30 \mathrm{~mL}$, antibiotikummal kiegészített LB tápoldatban, $37^{\circ} \mathrm{C}$-on, éjszakán át rázatva növesztett baktérium kultúrából történt. Az izoláláshoz a GeneElute Plasmid Miniprep Kit-et (Sigma) használtam. A tápoldatban felnőtt sejteket összesen 4,5 mL kultúra mintákból külön mikrocentrifugacsövekben gyüjtöttem össze centrifugálással (4700xg, 1 perc), majd $200 \mu \mathrm{L}$, hütött $\left(4{ }^{\circ} \mathrm{C}\right)$, Rnáz-tartalmú szuszpendáló oldatban vettem fel az üledéket. $200 \mu \mathrm{L}$ lízis puffert mértem rájuk, majd többször megforgattam az elegyet tartalmazó centrifugacsövet. A feltárt sejtekhez $350 \mu$ L neutralizáló oldatot adtam, ismét megforgattam a mikrocentrifugacsöveket és centrifugálás (16800xg, 10 perc) után a felülúszóval dolgoztam tovább. $500 \mu \mathrm{L}$ oszlop előkészítő oldattal kezeltem a plazmid tisztító oszlopot. Az oszlopra $750 \mu \mathrm{L}$ elöbb említett felülúszót mértem és centrifugálással (16800xg, 1 perc) felkötöttem az oszlopra. Majd 2x750 $\mu \mathrm{L}$ mosó pufferrel és centrifugálással (16800xg, 1 perc) távolítottam el a nem specifikusan kötődő anyagokat. Az oszlopra kötődő plazmid DNS-t 2x20 $\mu$ L ultratiszta, ioncserélt vízzel, centrifugálással (16800xg, 1 perc) eluáltam. A tisztított plazmid koncentrációját NanoDrop ${ }^{\mathrm{TM}} 1000$ Spektrofotométer (Thermo Scientific) segítségével határoztam meg a minta abszorbancia értéke alapján.

\subsubsection{Irányított helyspecifikus mutagenezis}

A mutagenezist pBluescript SK+ vektorba épített SqrF fehérjét kódoló DNS fragment segítségével (pBSQNNS) végeztem. A reakcióelegy 20 ng templát DNS-t, $200 \mu \mathrm{M}$ dNTP-t, 10x Phusion HF puffert és a megfelelő mutációt hordozó primer párok tagjaiból 125-125 ng-ot tartalmazott $50 \mu \mathrm{L}$ végtérfogatban. Az in vitro szintézist 2,5 U Phusion DNS polimerázzal végeztem 30 másodperc $95^{\circ} \mathrm{C}$-os kezdeti denaturációs lépést és a 16 cikluson keresztül ismételt 30 másodperc $95{ }^{\circ} \mathrm{C}, 1$ perc $55^{\circ} \mathrm{C}, 6$ perc $72{ }^{\circ} \mathrm{C}$-os lépéseket magába foglaló programmal. A keletkező terméket a reakcióelegyhez adott $10 \mathrm{U} / \mu \mathrm{L}$ DpnI enzimmel 
emésztettem 1 órán át, $37{ }^{\circ} \mathrm{C}$-on, majd E. coli XL-1 Blue törzsbe transzformáltam, a kész konstrukciókat szekvenálással ellenőriztem.

\subsubsection{DNS végek módosítási eljárásai}

A restrikciós emésztéseket, DNS végek tompítását T4 és Klenow polimerázzal (Fermentas), alkalikus foszfatáz kezelést és polinukleotid kináz kezelést a Fermentas cég által forgalmazott enzimekkel végeztem, az enzimek saját, gyári pufferében a cég instrukciói alapján.

\subsubsection{Ligálás}

A beépítendő DNS fragmentumot háromszoros feleslegben adtam a meghasított vektorhoz. A ligáláshoz a Fermentas cég T4 DNS ligáz enzimét alkalmaztam 5x-ös Rapid Ligáz Pufferben a cég instrukciói alapján.

\subsubsection{Agaróz gélelektroforézis}

A tisztított DNS mintákat, PCR reakciók termékeit és a restrikciós enzimekkel emésztett DNS fragmentumokat agaróz gélelektroforézis segítségével ellenőriztem. A DNS fragmentumok elválasztásához 1\%-os, $0,1 \mu \mathrm{g} / \mathrm{mL}$ etídium-bromidot tartalmazó agaróz gélt használtam 1x TAE pufferben $90 \mathrm{~V}$ futtatási feszültséggel.

\subsubsection{DNS fragment izolálás}

Az agaróz gélből a megfelelő DNS szakaszt tartalmazó géldarabokat steril pengével vágtam ki. A fragmentizolálást a gélből a QIAquick Gel Extraction Kittel (QIAGEN) végeztem. A kivágott géldarabhoz a tömege háromszorosának megfelelő térfogatú QG puffert adtam (1 egység gél: $100 \mathrm{mg}=100 \mu \mathrm{L}$ ), majd $50{ }^{\circ} \mathrm{C}$-on inkubáltam az agaróz teljes feloldódásáig. Ezt követően egy géltérfogatnyi mennyiségü izopropanolt adtam hozzá. Az oszlop előkészítése után a feloldódott géldarabot tartalmazó oldatot az oszlopra mértem, majd centrifugáltam (16800xg, 1 perc). Az oszlopot $750 \mu \mathrm{L}$ PE pufferrel mostam kétszer. A DNS-t 2 x $15 \mu \mathrm{L}$ steril, ioncserélt vízzel, centrifugálással (16800xg, 1 perc) eluáltam. 


\subsubsection{Analitikai polimeráz láncreakciók}

Az ellenőrző PCR reakcióelegyet $20 \mu \mathrm{L}$ végtérfogatban állítottam össze, templátként tisztított plazmidot vagy baktérium kolóniából készített szuszpenziót, polimerázként DreamTaq (Thermo Scientific) enzimet használtam. Reakcióelegy további komponensei: $200 \mu \mathrm{M}$ dNTP, 10x Green DreamTaq puffer, primer párok tagjaiból 125-125 ng.

\subsubsection{Nukleotidsorrend meghatározása}

A DNS szekvencia meghatározások automata kapilláris szekvenálással készültek specifikus oligonukleotidok felhasználásával (SZBK Szekvenáló Laboratórium).

\subsection{9. $\quad s q r D$ és $s q r F$ gének csonkítását eredményező DNS} konstrukciók előállítása

$\mathrm{Az} s q r D$ gén „upstream” 5' végi régióját osqr1F - osqr2R indítószekvenciák és Phusion polimeráz használatával felsokszoroztam (ld. 11.1.5.-os függelék). A keletkezett terméket fragmentizolálás után foszforiláltam, majd ligálással EcoRV restrikciós enzimmel hasított és alkalikus foszfatázzal (FastAP) kezelt pBluescript vektorba jutattam (pSQRUP) (ld. 11.1.4.-os függelék). Az előbb említett módon jártam el a gén „downstream” 3’ végi régiójával az oqsr3F- osqr4R oligonukleotidok segítségével, ezzel létrehozva a pSQRDO vektort. Ezen vektorokat XL-1 Blue MRF' klónozó E. coli törzsbe transzformáltam. Plazmidizolálást követően a pSQRUP vektort EcoRI és BamHI enzimekkel emésztettem, majd ugyanezen restrikciós endonukleázokkal és FastAP-val kezelt pK18mobSacB vektorba ligáltam (pKSQRUP). A kapott plazmidot XbaI - HindIII és FastAP enzimekkel emésztve, továbbá a pSQRDO vektorból az előbb leírt enzimekkel kiemésztett - „downstream” régió fragmentet egyesítve jött létre a pKDSQR vektor.

A müködésképtelen SqrF fehérje érdekében az $s q r F$ gén „upstream” régióját Phusion polimeráz és osqn3F - osqn4R oligonukleotidok segítségével felsokszoroztam, majd fragmentizolálás után foszforiláltam. Ezen fragmentet EcoRV enzimmel hasított és defoszforilált pBluescript vektorba jutattam (pBNUP). A „downstream” régiót kódoló DNS szakasszal hasonlóképpen jártam el az osqn5F - osqn6R indítószekvenciák segítségével (pBNDO). A pBNUP plazmidból HindIII és PstI restrikciós enzimekkel való emésztést követően kapott fragmentet az azonos endonukleázokkal felhasított $\mathrm{pK} 18 \mathrm{mobSacB}$ vektorba 
jutattam (pKNUP). A gén ,downstream” régióját tartalmazó pBNDO plazmid BamHI; EcoRI enzimekkel való emésztését követően kapott DNS szakaszt az előbb leírt restrikciós endonukleázokkal hasított és defoszforilált pKNUP vektorral egyesítettem (pKDSQN).

\subsubsection{Rekombináns SqrD és SqrF fehérjét termelő expressziós vektorok}

Az expressziós vektorok elkészítéséhez a $T$. roseopersicina genomjában azonosított sqrD gént hordozó DNS molekulát az osqr10F - osqr11R illetve az osqr21F - osqr22R oligonukleotid párok (ld. 11.1.5.-os függelék) segítségével kromoszómális DNS templátról induló, Pfu polimerázt használó, PCR felsokszorozással állítottam elő. A PCR termékeket T4 polinukleotid kináz felhasználásával foszforiláltam, ezt követően EcoRV restrikciós enzimmel hasított és alkalikus foszfatázzal kezelt pBluescript vektorba építettem be. Ligálást követően a reakcióelegyeket $E$. coli XL1-Blue sejtekbe transzformáltam, amelyeket IPTG-t, X-gal-t és ampicillint tartalmazó LB táplemezre szélesztettem ki. A másnapra megjelenő telepek közül a fehér kolóniák olyan plazmidokat hordoztak, amelyek tartalmazták az sqrD gént (pBSQR) illetve az sqrD gént linker-StrepII-Xa faktor hasítóhelyet kódoló DNS szakasszal fúzionáltatva (pBSQRNS). A következő lépésben a $\mathrm{pBSQR}$ vektoron kódolt srqD gént a pDSK6CrtKm expressziós vektorba építettem be olyan módon, hogy azonos leolvasási keretben fúzionáltatva legyen a vektor azon DNS szakaszával, ami Strep-II és FLAG affinitás peptideket kódolja. A pBSQRNS plazmidon kódolt $s q r D$ gén változattal is ugyanúgy cselekedtem, de a gén végén található stop kodon miatt a képződő fehérje csak az N-terminálison fog affinitás peptidet tartalmazni. Mindkét plazmidot NdeI és EcoRI restrikciós endonukleázokkal emésztettem, majd fragmentizolálással nyertem ki a géneket tartalmazó DNS szakaszokat. A pDSK6CrtKm expressziós vektort is NdeI és EcoRV endonukleázzal hasítottam, majd fragmentizolálással kinyertem a vektor nagyobb méretű fragmentjét. Ezzel a szakasszal egyesítettem az SqrD variánsokat kódoló DNS fragmenteket. A ligálási reakció termékeit ebben a lépésben is transzformálással juttattam be E. coli XL1-Blue sejtekbe. A fehér telepeket kiválogatva kaptam meg a pDSQR és a pDSQRNS expressziós vektorokat (8. ábra), amelyeket szekvenálással ellenőriztem. 
A

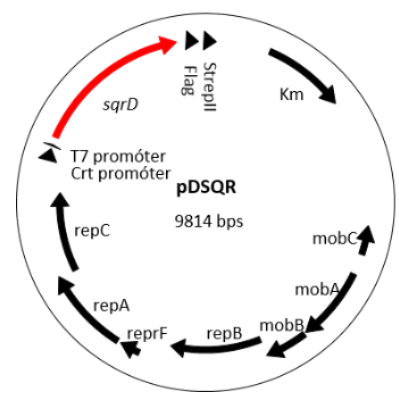

B

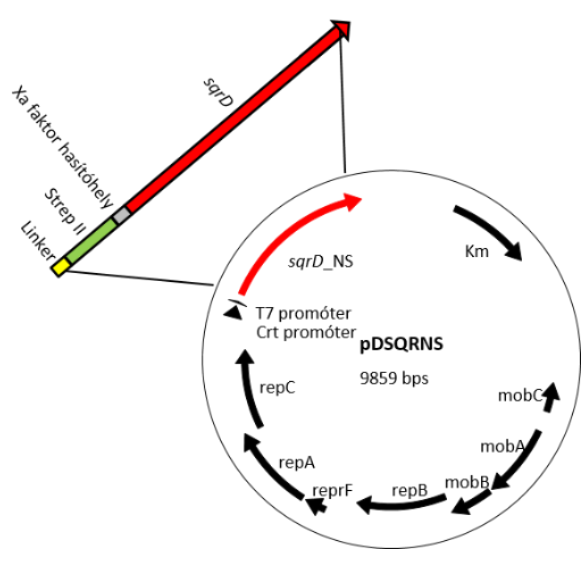

8. ábra: Rekombináns SqrD fehérjéket termelő expressziós vektorok sematikus ábrája

Az $s q r F$ gén esetében az osqn1N - osqn2R illetve osqn11F- osqn12R indítószekvencák és Pfu polimeráz használatával sokszorosítottam fel a gént kódoló DNS szakaszt T. roseopersicina BBS genomról. A kapott PCR termékeket 5' végeiken foszforiláltam T4 polinukleotid kináz alkalmazásával. Az így kapott DNS szakaszokat egy EcoRV restrikciós enzimmel hasított és FastAP kezelt pBluescript vektorba jutattam. Ligálást követően a DNS-t betranszformáltam E. coli XL1-Blue kompetens sejtekbe. A másnapra felnövő telepek közül azon kolóniákat választottam ki, amelyek tartalmazták az sqrF gént, illetve az sqrF gént linker-StrepII-Xa faktor hasítóhelyet kódoló DNS szakasszal fúzionáltatva ( $\mathrm{pBSQN}$ és pBSQNNS). Az sqrF génváltozatok expressziós vektorba építéséhez a kapott vektorokat előbb HindIII enzimmel hasítottam, a kialakult túlnyúló végeket Klenow enzimmel feltöltöttem, majd NdeI enzimmel is megemésztettem. Fragmentizolálással kinyertem az sqrF gén variánsokat tartalmazó DNS szakaszokat, amiket PstI-el emésztett és T4 DNS polimeráz enzim segítségével tompított, majd NdeI restrikciós enzimmel is meghasított pDSK6CrtKm expressziós vektor nagy fragmentjével egyesítettem. A pDSQN konstrukció biztosítja, hogy a róla termeltetett fehérje C-terminális végéhez StrepII és Flag affinitás peptidek legyenek fúzionáltatva, míg a pDSQNNS expressziós vektorról képződő rekombináns SqrF fehérje az N-terminális végén tartalmaz StrepII affinitás peptidet (9. ábra). 
A

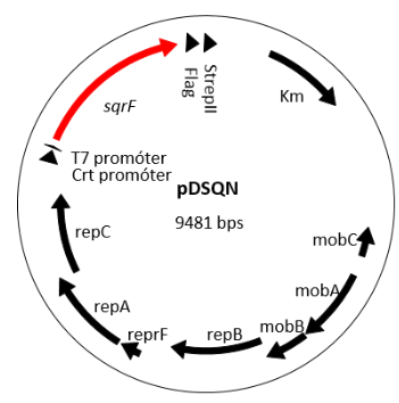

B

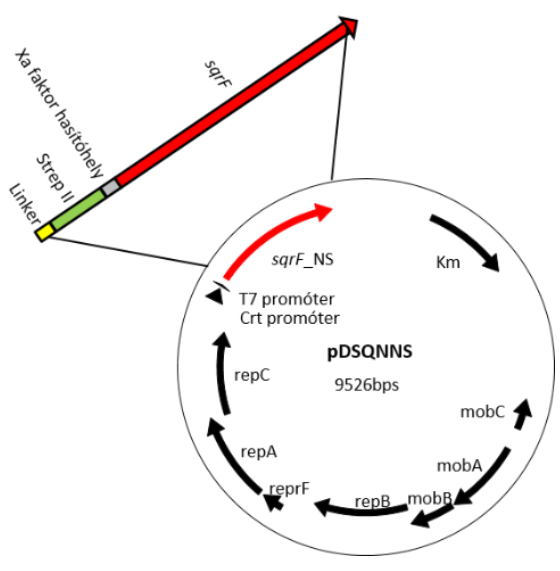

9. ábra: Rekombináns SqrF fehérjéket termelő expressziós vektorok sematikus ábrája

\subsection{Baktériumok transzformálása}

\subsubsection{Kémiai kompetens sejt készítés}

Az XL1-Blue MRF' és S17-1 $\lambda$ pir E. coli sejteket $50 \mathrm{~mL}$ SOB tápoldatban $\mathrm{OD}_{600 \mathrm{~nm}}=0,4-0,6$-ig növesztettem $18{ }^{\circ} \mathrm{C}$-on, ezt követően a kultúrákat 10 percig jégen hütöttem, majd 2500xg-n, 10 percig $4{ }^{\circ} \mathrm{C}$-on centrifugáltam. Az összegyült sejteket jégen tartva $16 \mathrm{~mL}$ TB pufferben felszuszpendáltam és újra centrifugáltam $\left(2500 \mathrm{xg}, 10\right.$ perc, $\left.4^{\circ} \mathrm{C}\right)$. A sejteket $4 \mathrm{~mL}$ TB pufferben felszuszpendáltam, a sejtszuszpenziót $300 \mu \mathrm{L}$ DMSO hozzáadását követően 10 percig jégen inkubáltam. Ezután $100 \mu \mathrm{L}$-enként, elöre lehütött 1,5 mL-s mikrocentrifugacsövekbe szétosztva, folyékony $\mathrm{N}_{2}$-ben fagyasztottam le a kompetens sejteket, majd $-80^{\circ} \mathrm{C}$-on tároltam öket [81].

\subsubsection{E. coli transzformálása}

Az eljárás során a transzformálandó DNS-t $100 \mu \mathrm{L}$ korábban elkészített, $-80{ }^{\circ} \mathrm{C}$-on tárolt, jégen felolvasztott $E$. coli kompetens sejtekhez adtam hozzá, melyet 15 percig jégen tartottam, amit egy 55 másodpercig tartó $42{ }^{\circ} \mathrm{C}$-os hösokk követett. Egy pár percig tartó hütés után $900 \mu \mathrm{L}$ SOC és $8 \mu \mathrm{L} 50 \%$-os glükóz oldatot adtam hozzá. Az elegyet 1 órán át $37^{\circ} \mathrm{C}$-on $500 \mathrm{rpm}$ sebességgel rázattam. Végül a sejteket a megfelelö antibiotikummal kiegészített LB lemezre szélesztettem ki. 


\subsubsection{Konjugálás T. roseopersicina sejtekbe}

A T. roseopersicina transzformációját konjugációval hajtottam végre. A donort, vagyis mobilizálandó plazmidot tartalmazó S17-1 $\lambda$ pir E. coli sejteket a megfelelő antibiotikum jelenlétében $\mathrm{OD}_{600 \mathrm{~nm}}=0,6$ eléréséig növesztettem $37^{\circ} \mathrm{C}$-on. A recipienst, vagyis T. roseopersicina sejteket $28^{\circ} \mathrm{C}$-on, a megfelelő antibiotikum jelenlétében $\mathrm{OD}_{600 \mathrm{~nm}}=1,8$ eléréséig előtenyésztettem. A felnőtt kultúrákat centrifugáltam $\left(4700 x g, 10\right.$ perc, $\left.4{ }^{\circ} \mathrm{C}\right)$, a leülepedett sejteket kétszer, 4-4 mL Pfennig-féle oldatban felszuszpendáltam, majd centrifugáltam az antibiotikum eltávolítása érdekében. Ezt követően ismét centrifugáltam (4700xg, 10 perc, $4{ }^{\circ} \mathrm{C}$ ), majd 100-100 $\mu \mathrm{L}$ Thiocapsa sóoldatban (ld. 11.1.6.-os függelék) szuszpendáltam. Az így kapott donor és recipiens sejteket összekevertem és konjugációs táptalajra cseppentettem ki. A csepp beszáradása után a lemezt fényen, levegőn, $28^{\circ} \mathrm{C}$-on, éjszakán át inkubáltam. Másnap a sejteket fogpiszkálóval felszedtem és $1 \mathrm{~mL}$ Thiocapsa sóoldatban felszuszpendáltam, 10x-es hígítási sort készítettem, majd a lépcsőkből 100-100 $\mu \mathrm{L}$ mennyiséget antibiotikumot tartalmazó szelekciós lemezre (PCA) szélesztettem [82].

A lemezeket Oxoid AnaeroGen $\left(\mathrm{N}_{2}, \mathrm{CO}_{2}\right)$ anaerobizáló rendszerrel oxigénmentesített anaerob dobozban inkubáltam 14 napig, $28^{\circ} \mathrm{C}$-on, folyamatos megvilágítással.

\subsection{4. $\quad s q r$ génekben mutáns T. roseopersicina törzsek}

\section{ellenőrzése}

A genomról kifejeződő gének elrontását eredményező DNS konstrukciókat (ld. 11.1.4.-es függelék), melyeket először konjugációt elősegítő E. coli S17-1 ( $\lambda$ pir) sejtbe transzformáltam, majdT. roseopersicina sejtekbe jutattam konjugáció segítségével. Az elsődleges rekombinánsok szelekciója kanamicin tartalmú PCA táplemezen történt, majd a pozitív klónokat antibiotikum-mentes PC tápoldatban növesztettem. Ezután a szelekció 3\% szukrózzal kiegészített PCA táplemezen történt. A szukróznak ellenálló, de kanamicin érzékeny telepeket szekvenálással ellenőriztem. 


\subsection{Fehérjetermeltetés és tisztítás}

\subsubsection{Fehérjetermelö E. coli sejtek feltárása, membrán frakció előállítása}

$\mathrm{Az}$ E. coli sejteket az 4.2.1. pontban leírt növesztési körülmények szerint szaporítottam fel a növekedési fázis exponenciális szakaszáig $\left(\mathrm{OD}_{600 \mathrm{~nm}}=0,8\right)$, majd különböző koncentrációjú IPTG hozzáadásával indukáltam az expressziót változó ideig és különböző hömérsékleten. Az így kapott kultúrák sejtjeit centrifugálással (8300xg, 10 perc, $4{ }^{\circ} \mathrm{C}$ ) gyüjtöttem össze. A tápoldattól elválasztott sejteket TBS oldatban (ld. 11.1.1.-es függelék) szuszpendáltam fel. A szuszpenziót szonikálással tártam fel egy Sonoplus típusú ultrahangos szonikátorral (Bandelin), VS 70/T szonikáló fejjel, 3 perc 20 másodpercig tartó 8x15 másodperces programot alkalmazva. A folyamat során a mintákat jégen tartottam a felmelegedés elkerülése érdekében. A feltáratlan sejteket, kénkristályokat, sejtfalmaradványokat centrifugálással $\left(27000 x \mathrm{xg}, 15\right.$ perc, $\left.4{ }^{\circ} \mathrm{C}\right)$ távolítottam el, a felülúszót ultracentrifugáltam (UC) (Sorvall WX Ultra Series 90 típusú ultracentrifuga, T-1270 típusú rotor, $100000 \mathrm{xg}, 90$ perc, $4{ }^{\circ} \mathrm{C}$ ). A szolubilis frakciónak megfelelő felülúszót és a membrán frakciónak megfelelő TBS pufferben felszuszpendált csapadékot $-20{ }^{\circ} \mathrm{C}$-on tároltam a felhasználásig.

\subsubsection{Fehérjetermelö $T$. roseopersicina sejtek feltárása, membrán frakció előállítása}

A T. roseopersicina sejteket az 4.2.2. pontban leírt növesztési körülmények szerint szaporítottam fel, a leoltástól számított 5. napon dolgoztam fel őket. A felnőtt kultúra sejtjeit centrifugálással $\left(8300 \mathrm{xg}, 10\right.$ perc, $\left.4{ }^{\circ} \mathrm{C}\right)$ gyüjtöttem össze. A tápoldattól eltávolítása után a sejteket TBSSL oldatban (ld. 11.1.1.--es függelék) szuszpendáltam fel. A szuszpenziót $30^{\circ} \mathrm{C}$-on, 30 percig inkubáltam, majd a periplazma oldattal megegyező mennyiségü hütött, steril vizet adtam hozzá. Egy 10 perces jégen történő inkubációt követően a szferoplasztokat centrifugálással $\left(13700 x g 10\right.$ perc, $\left.4{ }^{\circ} \mathrm{C}\right)$ választottam el a periplazmát tartalmazó felülúszótól. A szferoplasztokat TBS-ben szuszpendáltam fel, majd szonikálással tártam fel. Ezt Bandelin Sonoplus típusú ultrahangos szonikátorral hajtottam végre VS 70/T szonikáló fejjel, 3 perc 20 másodpercig tartó 8x15 másodperces programot alkalmazva. A folyamat során a mintákat jégen tartottam a felmelegedés elkerülése érdekében. A feltáratlan sejteket, 
kénkristályokat, sejtfalmaradványokat centrifugálással $\left(27000 \mathrm{xg}, 15\right.$ perc, $\left.4{ }^{\circ} \mathrm{C}\right)$ távolítottam el. A sejt kivonatot tartalmazó felülúszót ultracentrifugálásnak (Sorvall WX Ultra Series 90 típusú ultracentrifuga, T-1270 típusú rotor, 100000xg, 90 perc, $4{ }^{\circ} \mathrm{C}$ ) vetettem alá. A membrán frakciónak megfelelő csapadékot TBS pufferben szuszpendáltam fel és tároltam $-20{ }^{\circ} \mathrm{C}$-on felhasználásig.

\subsubsection{Fehérje membránból való felszabadítása}

A $0,12 \mathrm{~g} / \mathrm{mL}$ koncentrációjú membrán frakciót elsőként $10 \mu \mathrm{M}$ EDTA $\mathrm{pH}=8,00$ oldattal inkubáltam 30 percig $25^{\circ} \mathrm{C}$-on $160 \mathrm{rpm}$ rázatással. Majd ezt kiegészítettem 1,45M végső koncentrációjú $\mathrm{NaBr}$ oldattal, és további 1 óráig rázattam azonos körülmények között. Detergensekkel való fehérje felszabadítás esetén a membrán frakcióhoz különböző koncentrációban hozzáadott különféle nem-ionos vagy ikerionos detergensekkel történt a kezelés 1 óra hosszat, különböző hőmérsékleten (az aktuális értékek az Eredmények fejezetben találhatóak). Az elegyet ultracentrifugálásnak (Sorvall WX Ultra Series 90 típusú ultracentrifuga, T-1270 típusú rotor, 200000xg, 120 perc, $4{ }^{\circ} \mathrm{C}$ ) vetettem alá. A keletkezett, a felszabadított fehérjéket tartalmazó felülúszót felhasználásig $20^{\circ} \mathrm{C}$-on tároltam.

\subsubsection{Fehérje tisztítás affinitás oszlop kromatográfiával}

Az ultracentrifugálást követően a felszabadított fehérjéket tartalmazó felülúszót affinitás kromatográfia segítségével tisztítottam. Az oszloptöltetet (Strep-tactin Superflow 50\% szuszpenzió, IBA) gravitációs átfolyó oszlopba töltöttem, majd mosó pufferrel (TBS, $\mathrm{pH}=8,0)$ néhányszor átmostam az esetleges szennyeződések eltávolítása érdekében. A felülúszót az oszloptöltettel elegyítve 90 percig, szobahőmérsékleten, folyamatos forgatás mellett inkubáltam. Az átfolyó összegyüjtése után az oszlopot kétszeres oszloptérfogattal 8 mosó frakción keresztül mosópufferrel (TBS, $\mathrm{pH}=8,00)$ átmostam. Az oszlophoz kötődött fehérjét négyszer fél oszloptöltetnyi elúciós pufferrel eluáltam. Ezután az oszlopot háromszoros oszloptérfogatnyi regeneráló oldattal kezeltem, majd az oszlopot mosópufferrel (TBS, $\mathrm{pH}=10,10)$ háromszor átmosva távolítottam el a regeneráló oldatot. Ezt követően TBS-sel $(\mathrm{pH}=8,00)$ kétszer átmostam az oszlopot, hogy visszaállítsam a $\mathrm{pH}=8,00$ értéket. Az újra felhasználható oszlopot $4{ }^{\circ} \mathrm{C}$-on tároltam a következő használatig. 


\subsection{Poliakrilamid gélelektroforézis technikák}

\subsubsection{Denaturáló poliakrilamid gélelektroforézis (SDS-PAGE)}

A fehérjék molekulatömeg szerinti elválasztásához SDS-PAGE módszert használtam, melyhez 1,5 mm vastagságú, 10\%-os denaturáló poliakrilamid gélt készítettem. Átlalában $1 \mu \mathrm{g}$ fehérjemintát 4X SDS tartalmú felvivő pufferben 15 percig $95{ }^{\circ} \mathrm{C}$-on inkubáltam, majd a mintákat a gél zsebeibe mértem. A futtatás TGS pufferben, kezdetben $60 \mathrm{~V}$, majd a fehérjék szeparáló gélbe érkezése után $120 \mathrm{~V}$ feszültséggel történt. Futtatás után a gélt fixáló oldatban (30\% etanol, $10 \%$ ecetsav) 1 óráig inkubáltam, majd Blue Silver festékkel éjszakán át festettem. A gél hátterét 1\%-os ecetsavas mosással távolítottam el.

\subsubsection{Natív poliakrilamid gélelektroforézis}

A tisztított fehérjék negyedleges szerkezetének vizsgálatát denaturáló ágensektől mentes natív gélen végeztem. Az 1,5 mm vastagságú 5-15\% grádiens géleket TG puffer (ld. 11.1.1.-es függelék) rendszerben futtattam meg $100 \mathrm{~V}$ feszültséggel 4 órán keresztül. A gélt egy kétcsatornás grádiens gélöntő (BioRAD) segítségével készítettem el, melynek egyik csatornájába 15\%-os, a másik csatornába pedig 5\%-os gélt (ld. 11.1.1.-es függelék) juttattam. A fehérje mintákat $4 \mathrm{X}$ Blue-natív felvivő pufferrel kevertem össze, ezután felvittem őket a gél zsebeibe. A futtatás 4 órán keresztül $100 \mathrm{~V}$ feszültséggel valósult meg.

\subsubsection{Western-blot hibridizáció}

A denaturáló és natív poliakrilamid gélelektroforézist követően a fehérjéket nitrocellulóz membránra (AmershamTM HybondTM-ECL) blottoltam TransBlot ${ }^{\circledR} \mathrm{SD}$ Semi-Dry Electrophorethic Transfer Cell (BioRAD) készülék segítségével (45 perc, $25 \mathrm{mV}$, transzfer puffer). A membránt ezután 1 órán át blokkoló oldattal (1\%-os tejpor PBS-T pufferben) elegyítettem, ezzel megakadályozva a nem-specifikus fehérjék kötődését. StrepMAB-Classic-HRP antitestet (IBA) használtam ellenanyagként 1:100000-es hígításban PBS-T pufferben. Szobahőmérsékleten, 1 órán át inkubáltam a membránt. Ezt követően PBS-T, majd PBS pufferrel mostam a membránt. Előhívás során 1 percig inkubáltam luminol és hidrogén-peroxid $3 \mathrm{~mL}$ térfogatú 1:1 arányú keverékével (Pierce, SuperSignal West Pico Rabbit IgG Detection Kit). A kemilumineszcens jelet CCD kamerával detektáltam (VersaDoc 4000MP (BioRAD). 


\subsection{Tisztított fehérjék jellemzéséhez alkalmazott módszerek}

\subsubsection{Fehérje mennyiség meghatározás Micro-Lowry módszerre1}

A fehérjékhez $800 \mu \mathrm{L}$ 0,25 M NaOH oldatot adtam, majd a C reagensböl $300 \mu \mathrm{L}-\mathrm{t}$ adtam a fehérje oldathoz és keverés után 15 percig szobahömérsékleten tartottam. Ezután $100 \mu \mathrm{L} 72 \%$-os Folin reagens hozzáadása után 30 perc inkubálást követően 750 nm-en mértem az oldat fényelnyelését fotométerrel (BIORAD SmartSpec 3000).

Az ismeretlen minták koncentrációját borjú szérum albuminból készített kalibrációs egyenes alapján állapítottam meg [83].

\subsubsection{Fehérje abszorpciós és emissziós spektrum meghatározás}

A tisztított fehérje abszorpciós spektrumának meghatározásához Nicolet Evolution 300 spektrofotométert használtam. A fényelnyelést $1 \mathrm{~cm}$ fényúttal rendelkező kvarcküvettában, 250-850 nm hullámhosszúságú tartományban mértem. A tisztított fehérje emissziós spektrumának meghatározásához QuantaMaster spektrofluorimétert (Photon Technology International) használtam 450 nm-es gerjesztő fénnyel. A kibocsájtott emissziót 470-610 nm-es tartományban kvarcküvettában mértem meg.

\subsubsection{Szulfid függő kinon redukáló aktivitás mérés}

Az SQR enzim aktivitás méréséhez szintén Nicolet Evolution 300 spektrofotométert használtam. A fényelnyelést $1 \mathrm{~cm}$ fényúttal rendelkező légmentesen zárható kvarcküvettákban mértem. Az $1 \mathrm{~mL}$ végtérfogatú $\mathrm{pH}=8,00$ reakcióelegy kísérletenként eltérő mennyiségü tisztított enzimet vagy membrán frakciót, elektrondonort, elektronakceptort és fehérje gátlószert tartalmazott. A reakcióelegy légterét nitrogén gázzal fúvattam át 5 percen keresztül az anaerobizálás érdekében. A mérés elött anaerob körülmények között állítottam elő a kísérletenként különböző koncentrációjú nátriumszulfid oldatot, majd ennek a reakcióelegyhez való hozzáadásával indítottam a reakciót. A fényelnyelés-változást $275 \mathrm{~nm}$-en mértem, mely az oxidált durokinon fényelnyelési maximuma. 


\subsubsection{SqrF enzim aktivációs energiájának meghatározása}

A Kelvinben megadott hőmérséklet reciprokának függvényében ábrázoltam az SqrF specifikus aktivitásának logaritmusát, majd a kapott pontokra egyenest illesztettem. Az egyenes meredekségéből számoltam ki az aktivációs energiát az Arrhenius-egyenlet segítségével: $\mathrm{k}=\mathrm{Ae}^{-\mathrm{Ea} / \mathrm{RT}}$.

\subsubsection{Tisztított fehérje FAD kofaktor tartalmának és kötésének vizsgálata}

Tisztított vad típusú enzimet tartalmazó mintát vagy abszolút metanolban forraltam 10 percig vagy kiegészítettem 5\% végkoncentrációjú triklór-ecetsavval, majd inkubáltam 10 percig szobahőmérsékleten. Ezután centrifugáltam az elegyet $\left(16800 x g, 10\right.$ perc, $\left.4{ }^{\circ} \mathrm{C}\right)$. A felülúszót átpipettáztam egy steril mikrocentrifugacsőbe, a csapadékot pedig felszuszpendáltam 0,25 M NaOH oldatban. Mindkét frakció fényelnyelését 250-600 nm hullámhosszúságú tartományban mértem. A feloldott csapadékot 10 kDa-s Amicon szürőn centrifugálás segítségével $\left(16800 x g, 120\right.$ perc, $\left.4{ }^{\circ} \mathrm{C}\right)$ átszürtem, majd a szürlet abszorbancia spektrumát megmértem a fent leírt módon.

\subsubsection{Szulfid tartalom meghatározás}

A $T$. roseopersicina sejteket módosított $2 \mathrm{~g} / \mathrm{L}$ nátrium-tioszulfátot tartalmazó Pfennig-féle tápoldatban megvilágítás mellett 2 napig neveltem. A kultúrák tápoldatát anaerob körülmények között nátrium-karbonát mentes tápoldatra cseréltem. Az így kapott kultúrákhoz $1 \mathrm{mM}$ vagy $2,5 \mathrm{mM}$ anaerob nátrium-szulfid oldatot adtam hozzá, majd megvilágítás mellett 2 óráig inkubáltam, mely időtartam alatt félóránként mintát vettem. A mintavételezés során $1 \mathrm{~mL}$ kultúrát szürtem át egy $0,22 \mu \mathrm{m}$-es fecskendőszürőn keresztül egy 2 mL-s lezárt, $100 \mu \mathrm{L}$ 7,4\%-os sósavat tartalmazó HPLC csőbe. A gáztérből $200 \mu \mathrm{L}$ mintát vettem Hamilton gázzáró mikrofecskendővel és injektáltam a Shimadzu GC-2010 típusú gázkromatográf split/splitless inletébe (split arány 0.5:1). A légtérkomponensek elválasztásához HP-PLOT-Q kolonnát használtam (30m*0,35mm*40 $\mu \mathrm{m}) 76,4 \mathrm{~mL} /$ perc áramlási sebességü nitrogén vivőgáz használatával $120{ }^{\circ} \mathrm{C}$ fokos kolonnatér hőmérséklet mellett. A hővezetőképességi detektor (TCD) hőmérséklete $150{ }^{\circ} \mathrm{C}$ volt [84]. A kénhidrogén 
mennyiségi meghatározása analitikai bizonylattal ellátott kénhidrogén:argon gázkeverék felhasználásával felvett kalibrációs egyenessel történt. 


\section{Eredmények}

\subsection{Az sqrD és sqrF gének azonosítása és in silico analízise}

A fotoszintetikus bíbor kénbaktériumok elsősorban redukált kénvegyületeket, például szulfidot hasznosítanak elektronforrásként növekedésük során. Ha nem közvetlenül szulfidot, hanem pl. tioszulfátot használunk, szulfid akkor is képződik a sejt kénanyagcsere folyamatainak különféle redox reakcióin keresztül. A szulfid oxidációs folyamatában részt vesznek a szulfid kinon oxidoreduktáz enzimek. Általánosan előfordul, hogy egy kénbaktérium több SQR fehérjét kódoló régiót is tartalmaz, melyek termékei különböző SQR típusba sorolhatóak. Az egyik legismertebb bíbor kénbaktérium, az A. vinosum egy IV. típusú (SqrD) és egy VI. csoportba tartozó (SqrF) enzimmel is rendelkezik [62]. Az SQR típusok közül ezek a csoportok a legkevésbé ismertek.

Az A. vinosum közeli rokona a fototróf bíbor kénbaktérium Thiocapsa roseopersicina nyers genom szekvenciája rendelkezésre áll (nem publikált adat). Ez nagyjából a becsült teljes genomméret 95\%-át fedi le. Megvizsgáltam in silico módszerekkel a $T$. roseopersicina genomot, mely során kettő nyitott leolvasási keretet azonosítottam, amelyek más bíbor kénbaktérium SQR típusú enzimeihez hasonló fehérjéket kódolnak.

A T. roseopersicina egyik membrán-kötött hidrogenáz enzimét (Hup hidrogenáz) kódoló operontól 3' irányban, azzal ellentétes orientációban helyezkedik el egy1458 bp hosszúságú nyitott leolvasási keret. Ezen géntől (KY595104) 5' irányban 90 bp távolságban, vele megegyező orientációban egy szulfát transzporter fehérjét kódoló gén (sulP) található (10. ábra). Az azonosított gén terméke egy 485 aminosavból álló, 52884 Da súlyú fehérje, melynek izoelektromos pontja 6,2, továbbá $80 \%$-os azonosságot mutat az A. vinosum IV. típusú szulfid kinon oxidoreduktázával (WP_012971338.1). Ezek alapján a gént sqrD-nek, míg termékét SqrD fehérjeként neveztem el.

A másik SQR típusú fehérjét kódoló DNS régió (KY595105), egy 1128 bp hosszú nyitott leolvasási keret. A géntől 5' irányban vele azonos irányultságú vélhetően arilészterázt kódoló gén (Aré), 3' irányban pedig egy feltételezhetően transzport fehérje génje (transzport) található (10. ábra). A vizsgált gén terméke 375 aminosav hosszúságú, számolt molekulatömege $41477 \mathrm{Da}$, izoelektromos pontja 8,83. A szekvencia vizsgálata kimutatta, hogy 80\%-ban azonos az A. vinosum piridin nukleotid-diszulfid oxidoreduktázként 
elnevezett VI. típusú SQR fehérjéjével (WP_012970409.1), emiatt SqrF fehérjének, génjét $s q r F$-nek neveztük el.

Az $s q r D$ és $s q r F$ genomi környezete alapján valószínüsíthető, hogy ezek a gének nem alkotnak más génekkel operont. Softberry BPROM [85] programmal mindkét gén esetében azok 5' régiójában azonosítani lehetett -10 és -35 konszenzus szekvenciát, tehát feltehetőleg aktív promóterrel rendelkeznek.

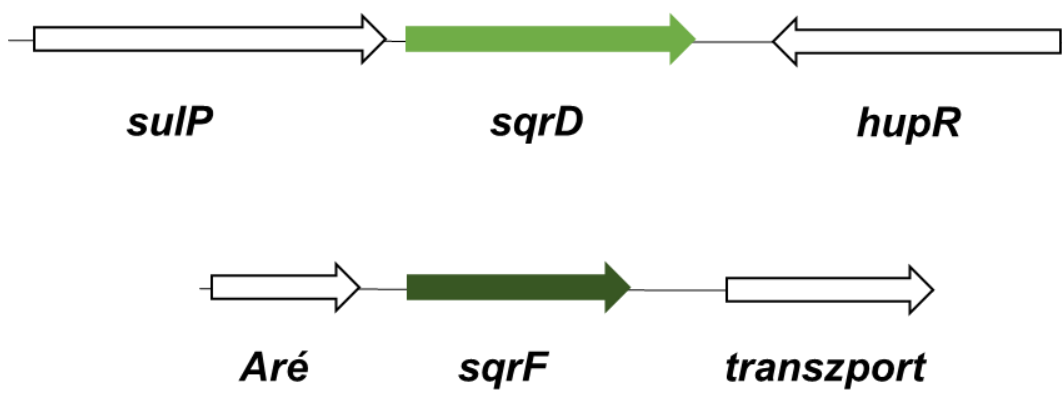

10. ábra: $T$. roseopersicina $s q r D$ és $s q r F$ gének genomi környezete

A két fehérje szekvenciája 26\%-os azonosságot mutat. A SOSUI program [86] alkalmazásával az SqrD és SqrF esetében sem lehetett azonosítani a fehérjék N-terminális végén ismert típusú szignál peptidet, valamint transzmembrán régiót.

Annak érdekében, hogy megtudjam az $s q r D$ és $s q r F$ gének termékeinek más SQR típusú fehérjékkel mutatott rokonságát filogenetikai analízist végeztem. Ennek során a $T$. roseopersicina szulfid kinon oxidoreduktáz fehérjéinek a csoportjukat jól reprezentáló SQR fehérjékkel, valamint több szulfid kinon oxidoreduktázzal rendelkező mikroorganizmusban jelen levő különböző típusokba sorolható SQR enzimekkel való evolúciós származási kapcsolatait vizsgáltam. 


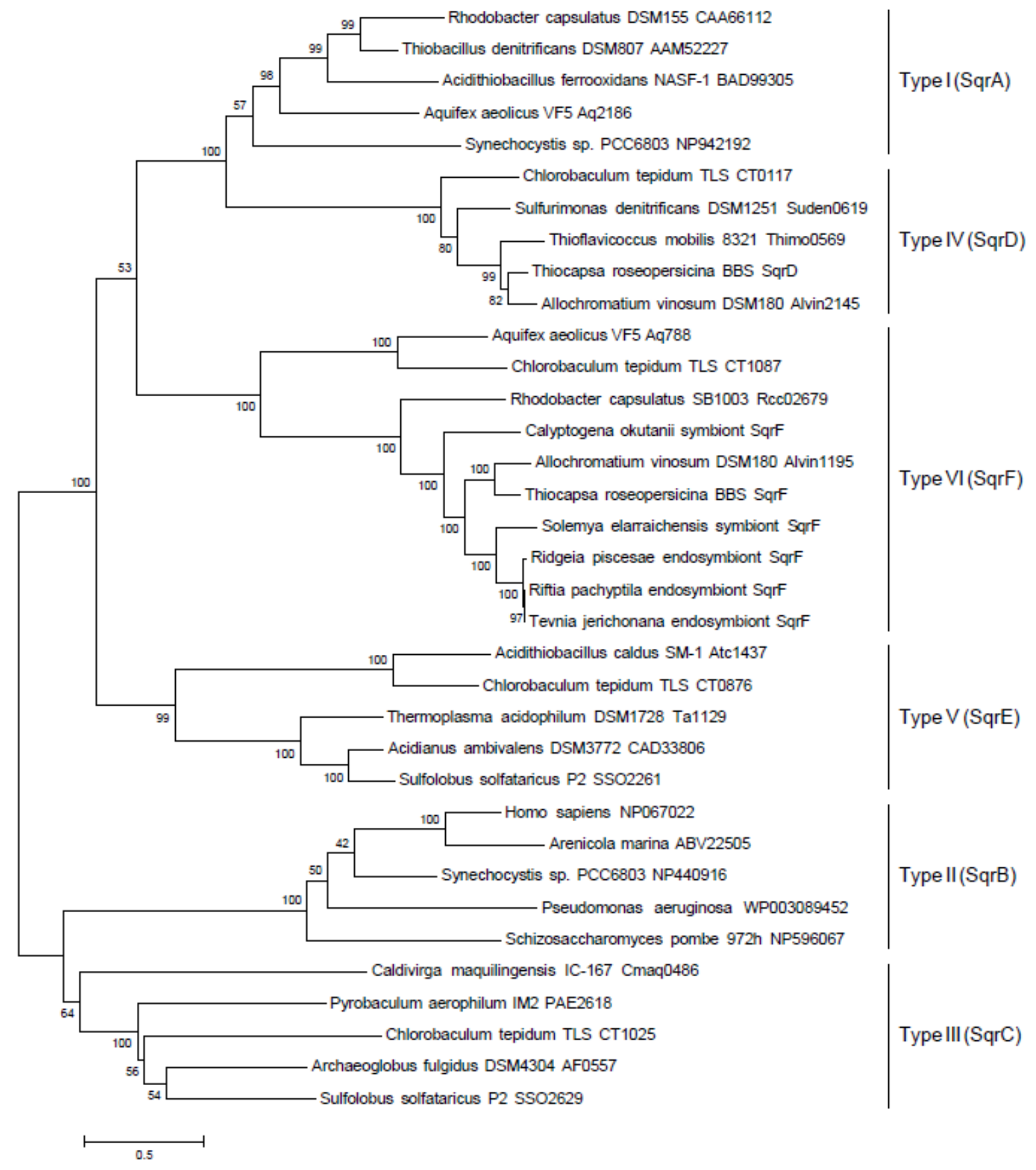

11. ábra: Az SqrD és az SqrF fehérjék filogenetikai analízise. A filogenetikai fa a Le- Gascuel modell [87] alapján „Maximum Likelihood” metódussal készült. Az ágak „Bootstrap” értékei 100 replikáció értékeit mutatja, az evolúciós analízis a MEGA6 [88] programmal készült

Az analízis eredményeként felállított filogenetikai fa jól mutatja, hogy az SqrD a IV. típusú SQR enzimek fejlődési ágán található, míg az SqrF a VI. típusú fehérjék közé tartozik az enzimcsaládon belül. A VI. típus egy heterogén csoport, melyen belül megtalálhatók zöld és bíbor kénbaktériumok Sqr fehérjéi, továbbá endoszimbionta mikroorganizmusokban 
azonosított enzimek is. A T. roseopersicina $\mathrm{SqrF}$ nagyon magas fokú rokonságot mutat az A. vinosum VI. típusú Sqr fehérjéjéhez, továbbá evolúciósan nagyon közel helyezkedik el az endoszimbionták SqrF fehérjéihez. Érdekes, hogy a zöld kénbaktérium C. tepidum VI. Sqr enzimtől a filogenetikai fán nagyobb távolságban található a $T$. roseopersicina $\mathrm{SqrF}$, a két fehérje aminosav sorrendje csak 32\%-ban azonos (11. ábra).

Az SQR-típusú fehérjék csoportosítása konzervált aminosavak és motívumok alapján épül fel [59]. Az SqrD fehérjében 3 konzervált cisztein található a 142., 178. és 413. pozícióban, amelyek megfeleltethetőek az A. aeolicus I. típusú (SqrA) fehérjében található 124., 156., 347. ciszteinnel [59]. Ezen felül 5 meghosszabbodott hurok és egy „sapka hurok” is azonosítható, továbbá a fehérjét hosszú C-terminális rész jellemzi. Ezen motívumok és konzervált aminosavak megléte alapján az SqrD fehérje egy IV. típusú szulfid kinon oxidoreduktáz fehérje (12. ábra).

Az SqrF fehérje szintén 3 konzervált ciszteinnel rendelkezik a 121., 272., 332. pozicíóban. A „sapka hurok”-nak nevezett motívum hiányzik ebből a fehérjéből, továbbá a C-terminális rész rövidebb, mint a többi csoportba tartozó SQR fehérje esetén. Mindezen jellemzők alapján az SqrF az SQR fehérjéken belül a VI. típusúak közé sorolható (12. ábra).
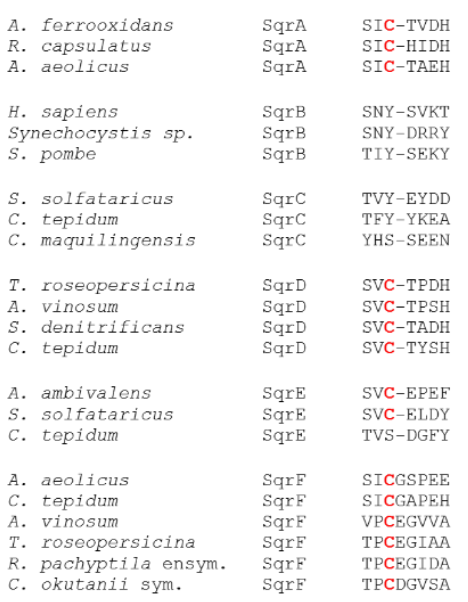

C121

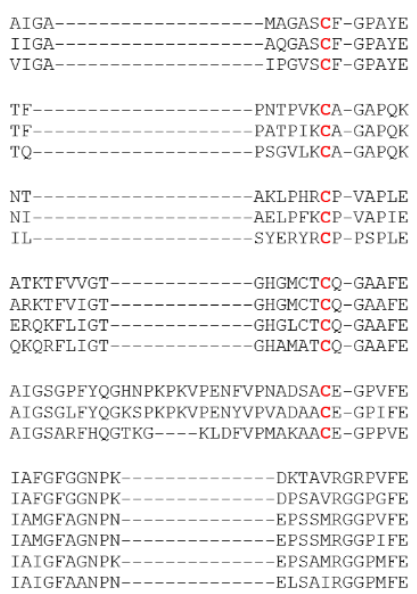

IAIGFAANPN- - -

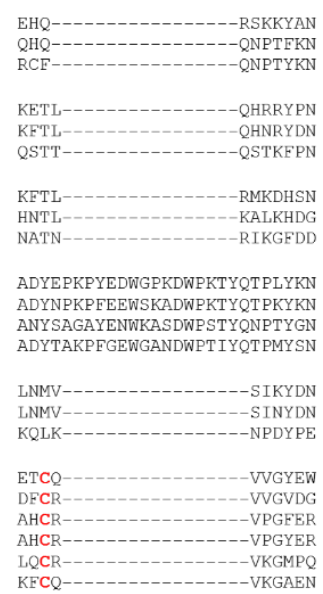

$\mathrm{C} 272$

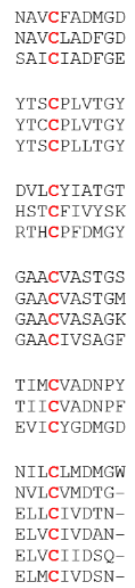

$\mathrm{C} 332$

12. ábra: A különbözö típusba tartozó SQR-típusú fehérjék szekvencia összehasonlítása. Pirossal kiemelve a konzervált ciszteinek láthatóak

Tehát megalapozott volt a gének elnevezése, mivel a $T$. roseopersicina genomban azonosított szulfid kinon oxidoreduktázt kódoló gének termékei filogenetikai analízisük és jellemző szekvenciaelemeik alapján a IV. és VI. típusban tartoznak. 


\subsection{Az sqrD és sqrF gének kifejeződése $T$. roseopersicina-ban}

A gének azonosítását követően megvizsgáltam az $s q r D$ és $s q r F$ gének kifejeződését vad típusú $T$. roseopersicina sejtekben. A sejteket alacsony nátrium-tioszulfát koncentráció mellett, szulfidot nem tartalmazó tápoldatban növesztettem, annak érdekében, hogy a sejtek anyagcsere folyamatai során ne képződjenek kénglobulusok (és ezeken keresztül endogén szulfid) és így meg lehessen vizsgálni az sqr gének kifejeződését szulfid mentes körülmények között. A kvantitatív RT-PCR mérések eredménye alapján elmondható, hogy az alkalmazott növesztési körülmények között az sqrF gén közel 2,5-szer magasabb expressziót mutat az sqrD-hez viszonyítva (13. ábra).

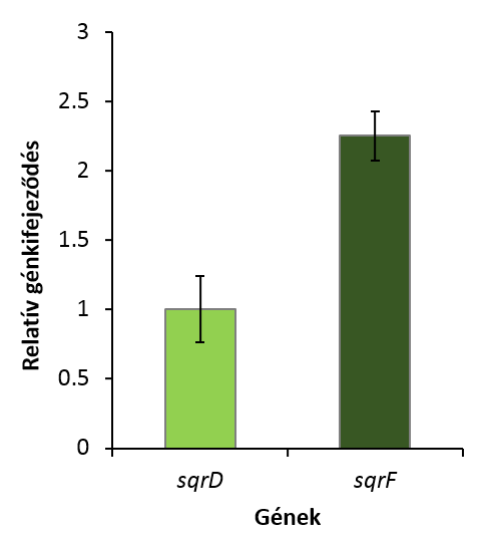

13. ábra: $s q r D$ és $s q r F$ gének egymáshoz viszonyított kifejeződése hozzáadott szulfidot nem tartamazó tápoldatban növesztett vad típusú T. roseopersicina sejtekben. Az sqrD génexpresszióját 1-nek állítottam be és ehhez viszonyítottam az $s q r F$ génkifejeződését

Szulfid oxidáló funkciót ellátó fehérjéket kódoló gének esetén felmerül a kérdés, hogy különböző koncentrációban hogyan hathat a szulfid a gének expressziójára. Ezen kérdés megválaszolására megmértem az $s q r D$ és $s q r F$ gének kifejeződését $T$. roseopersicina sejtekben 1 órányi 0,$1 ; 0,5 ; 1,0 ; 2,5$ és $5 \mathrm{mM}$ nátrium-szulfid jelenlétében történő inkubációt követően. A kénglobulus mentes sejteket alacsony tioszulfát alkalmazásával értem el, majd ezeket a sejteket egy szénforrást nem tartalmazó tápoldatban szuszpendáltam fel anaerob körülmények között, és sötétben inkubáltam 1 órán át. A sejtek nem voltak képekesek felhasználni a tápoldathoz hozzáadott szulfidot, így biztosítani tudtam a kísérlet kezdetekor fennálló különböző szulfid koncentrációk állandóságát, melyet gázkromatográf segítségével ellenőriztem A kísérlet elején és végén mintát vettem a kultúrákból és gáz fázisból 
meghatároztam a minták szulfid koncentrációját, melyek nem változtak a kísérlet alatt. A génexpressziók mértékét a szulfidot nem tartalmazó tápoldatban inkubált negatív kontroll sejtkultúra minták értékeihez viszonyítva adtam meg.

Az sqrD esetében a kifejeződés emelkedik a növekvő szulfid koncentrációval, amíg eléri a maximumát $1 \mathrm{mM} \mathrm{Na} 2 \mathrm{~S}$ mellett, ahol 14-szer magasabb expresszió figyelhető meg a kontrol sejtekhez képest. Az sqrF génexpresszió szintén növekszik a szulfid koncentráció emelésével, a legmagasabb értéket, 8,5-szörös növekedést 2,5 mM szulfid alkalmazásánál érte el (14. ábra).

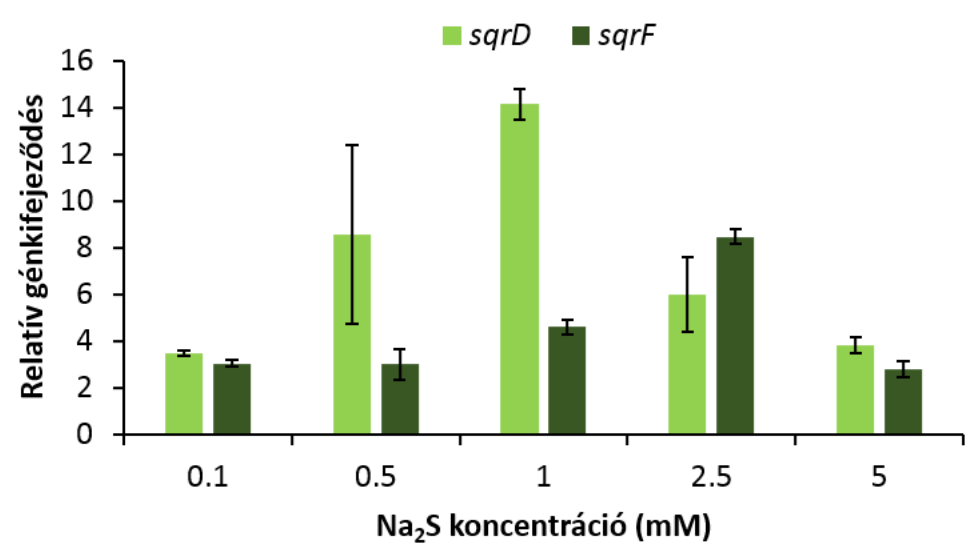

14. ábra: Az sqrD és $s q r F$ génexpresszió szulfid hatására bekövetkező növekedése különböző szulfid koncentráció mellett

\subsection{Szulfid kinon oxidoreduktázok részvétele a $T$. roseopersicina kénanyagcserében}

$\mathrm{Az}$ SqrD és SqrF fehérjék sejten belüli, a kénanyagcserében való szerepének bizonyítása végett, elöállítottam az $s q r D$ vagy $s q r F$ génben mutáns $T$. roseopersicina HOQR és HOQN törzseket az Anyagok és módszerek fejezetben ismertetett munkafolyamat során.

\subsubsection{Membrán kötött SqrD és SqrF fehérjék aktivitás vizsgálata in vitro}

Az SqrD és SqrF fehérjék szekvencia vizsgálata alapján mindkét fehérje SQR típusú, így feltételezhetően membrán kötöttek és szulfid függő kinon redukáló aktivitással bírnak. Ezen feltételezések bizonyítására a vad típusú BBS és a mutáns HOQR, HOQN T. roseopersicina törzseket $\mathrm{PC}$ tápoldatban neveltem az 4.2.2. fejezetben ismertetett 
körülmények között, majd membrán frakciót izoláltam a sejtekböl. A membrán frakcióban lévő fehéjék szulfid függő kinon redukáló aktivitását olyan reakcióelegy alkalmazásával vizsgáltam, mely tartalmazott a membrán frakción kívül elektrondonorként szulfidot, továbbá elektronakceptorként durokinont. A reakciót a hozzáadott durokinon redukáltsági szintjének változásával követtem nyomon.

Az eredmények alapján elmondható, hogy a mindkét SQR típusú fehérjét expresszáló BBS törzs aktivitásához képest, az SqrD fehérje hiánya miatt a HOQR membrán frakció aktivitása közel a felére csökkent. Az SqrF mutáns (HOQN) törzs esetében pedig a VI. típusú SQR enzim hiánya az aktivitás több mint 50\%-os csökkenéséhez vezetett (15. ábra).

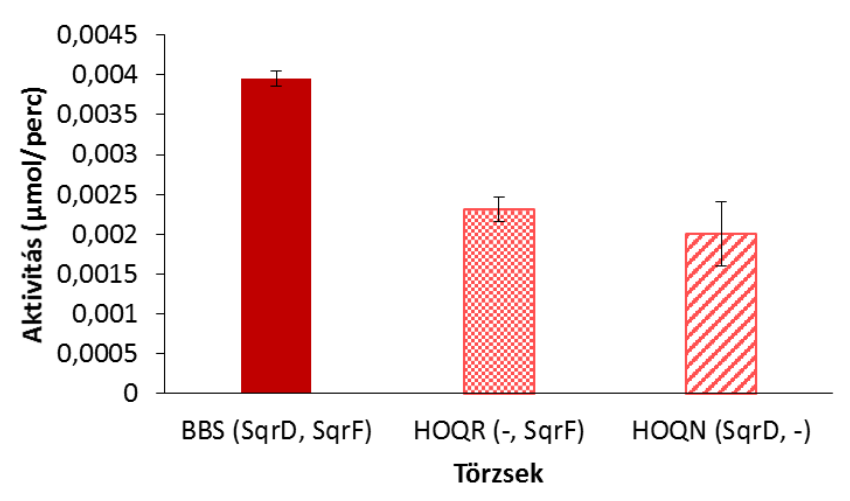

15. ábra: SqrD és SqrF fehérjéket tartalmazó illetve nem tartalmazó T. roseopsersicina törzsekből készített membrán frakciók szulfid függő durokinon redukáló aktivitása

Tehát ezen kísérleti elrendezéssel mérhető a $T$. roseopersicina törzsekből izolált membrán szulfid függő kinon redukáló aktivitása, továbbá kijelenthető, hogy az SqrD vagy az SqrF enzim hiánya csökkent aktivitást eredményez a mindkét enzimet tartalmazó pozitív kontroll membrán frakció aktivitásához képest.

\subsubsection{SqrD és SqrF fehérjék aktivitás vizsgálata in vivo}

Miután igazoltam, hogy az SqrD és SqrF a T. roseopersicina törzsek membrán frakcióiban szulfid függő kinon redukáló aktivitással bíró fehérjék, megvizsgáltam, milyen körülmények között milyen szerepet töltenek be a sejtek kénanyagcseréjében. Vizsgáltam, hogy az SqrD és SqrF fehérjék hiánya hogyan befolyásolja a sejtek in vivo szulfid felhasználási képességét. Mindkét enzimet tartalmazó GB1121 és a mutáns HOQR, HOQN törzseket alacsony koncentrációjú nátrium-tioszulfát elektronforrás mellett növesztettem. Az 
így kapott kénglobulusokat még nem tartalmazó sejtek tápoldatát lecseréltem anaerob módon olyan szénforrással is rendelkező médiumra, mely egyedüli redukált kénvegyületként szulfidot tartalmazott, majd megvilágítás mellett inkubáltam a mintákat. Ennek során meghatározott időnként megmértem a sejtek tápközegében jelen levő szulfid koncentrációját.

Az sqrD génexpressziós vizsgálata alapján megállapítottam, hogy az sqrD $1 \mathrm{mM}$ $\mathrm{Na}_{2} \mathrm{~S}$ koncentrációnál érte el kifejeződésének maximumát. Ezért a kontroll GB1121 és az SqrD mutáns HOQR sejtek szulfid felhasználási képességét $1 \mathrm{mM} \mathrm{Na}_{2} \mathrm{~S}$ mellett monitoroztam.

Mindkét törzs képes volt a Na2S-t felhasználni, azonban az SqrD mutáns HOQR törzs esetében már a 15. percnél látható, hogy kevesebb $\mathrm{S}^{2-}$-ot tudott oxidálni, mint a GB1121 sejtek és ezen különbség a további mintavételi időpontoknál tovább nőtt (16/A. ábra).

A

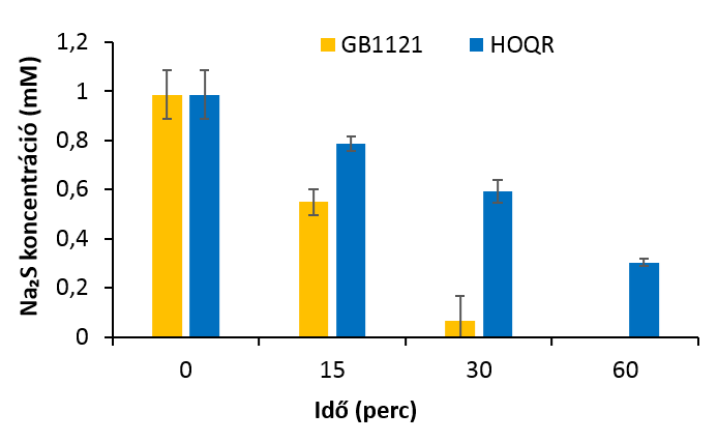

B

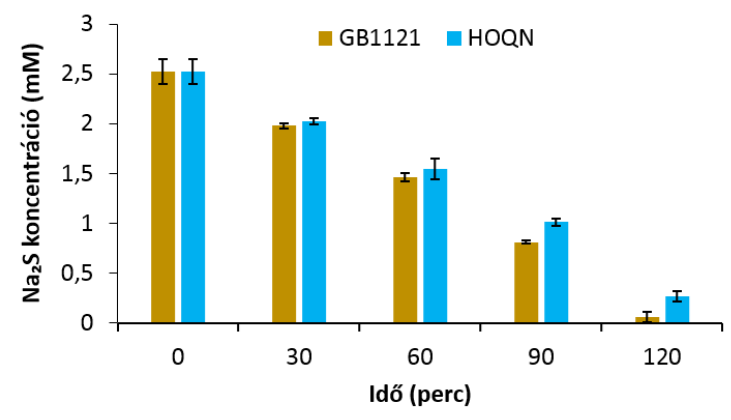

16. ábra: T. roseopersicina törzsek tápoldata szulfid tartalmának időbeni változása. (A) SqrD fehérjét tartalmazó és nem tartalmazó sejtek vizsgálata $1 \mathrm{mM} \mathrm{Na} 2 \mathrm{~S}$ hozzáadásával, (B) SqrF fehérjét tartalmazó és nem tartalmazó sejtek vizsgálata $2,5 \mathrm{mM} \mathrm{Na}_{2} \mathrm{~S}$ hozzáadásával

Az $s q r F$ gén legmagasabb expressziója 2,5 mM Na2 $\mathrm{S}$ alkalmazásakor valósult meg (14. ábra), így az SqrF fehérje kénanyagcserében való részvételének bizonyítása során a szintén kontroll GB1121 és a HOQN törzsek szulfid oxidáló aktivitását 2,5 mM Na2S koncentráció mellett vizsgáltam. Látható, hogy mind a GB1121, mind a HOQN törzs $\mathrm{S}^{2-}$ tartalma csökken az idő múlásával, azonban az SqrF mutáns törzs kis, de kimutatható mértékben lassabban volt képes felhasználni a $\mathrm{Na}_{2} \mathrm{~S}$-ot, különösképpen 1 óra elteltével (16/B. ábra). 
Tehát ezen kísérleti körülmények mellett az eredmények alapján kijelenthető, hogy mindkét fehérje részt vesz a $T$. roseopersicina kénanyagcseréjében, illetve felveti annak lehetőségét, hogy a vizsgált két szulfid kinon oxidoreduktázon kívül más enzim(ek) is végezhet(nek) szulfid oxidációt a sejteken belül.

\subsection{Az SqrD és SqrF fehérjék expressziója és tisztítása}

\subsubsection{Az SqrD és SqrF fehérjéket termelö expressziós vektorok}

A T. roseopsersicina kénanyagcseréjében szerepet játszó SqrD és SqrF fehérjék biokémiai jellemzéséhez továbbá katalitikus mechanizmusának felderítéséhez tisztított fehérjék szükségesek. Az SQR fehérjék tisztítását affinitás kromatográfiával terveztem, ezért első lépésben elő kellett állítanom olyan expressziós vektorokat, melyek rekombináns, affinitás peptiddel ellátott formában biztosítják a fehérjék kifejeződését. A pDSK6CrtKm (Balogh, személyes közlés) expressziós vektoron található replikációs origóknak köszönhetően az elkészített plazmidok képesek stabilan fennmaradni E. coli és T. roseopersicina sejtekben is. A vektorba épített génektől 5' irányban található T7 promóter biztosítja $E$. coli-ban a promótert követő gének kifejeződését, míg a T7 promótertől további $5^{\prime}$ irányban elhelyezett $c r t D$ promóter ugyanezt $T$. roseopersicina sejtekben teszi lehetővé [89]. A szulfid kinon oxidoreduktáz fehérje szekvenciák in silico analízise alapján feltételezhető, hogy mindkét előállítandó fehérje esetében a C- és $\mathrm{N}$-terminálison is funkcionálisnak tartott régiók találhatóak. Ezért aktív fehérjék termelődésének elérése céljából az SqrD és SqrF fehérjék C-, illetve N-terminálison StrepII affinitás peptiddel kiegészített változatait kifejező expressziós vektorokat is létrehoztam (ld. 4.3.10.).

\subsubsection{Rekombináns SqrD és SqrF fehérje termeltetése és tisztítása T. roseopersicina-ban}

A T. roseopersicina szulfid oxidáló enzimei E. coli-ban gyorsan, nagy mennyiségben termelődnek, ezáltal összecsapódnak. A termelt fehérjék a sejtfeltárást követő centrifugálás után a csapadék frakciójában voltak jelen. Nem sikerült a fehérjék termelődését számottevően lelassítani és így biztosítani azok szolubilis formáját, illetve speciális, hidegtürő chaperon fehérjéket is kifejező expressziós E. coli törzsekben való $\mathrm{SQR}$ kifejeztetés sem eredményezte a fehérje kicsapódás mértékének csökkenését, ezért 
a következőkben az SqrD és SqrF fehérjék homológ gazdában, T. roseopersicina-ban való expresszióját tüztem ki célul. Mindkét fehérje termelődött és Western analízis segítségével meghatároztam, hogy a sejtek membrán frakciójában detektálhatóak. Tehát a rekombináns úton termelődött SQR fehérjék T. roseopersicinában fiziológiásan megfelelő módon, a membránhoz kapcsoltan vannak jelen a sejten belül, ezért a fehérje tisztítás első lépése a fehérjék membránból való felszabadítása volt.

Membrán-kötött fehérjék membránból való kiszakítása után hidrofób felületük/felületeik miatt olyan ágensek jelenlétére van szükség, melyek képesek víz oldószer alapú közegben tartani a fehérjéket. Erre a feladatra legelterjedtebben detergenseket alkalmaznak, azon belül is a nem-ionos vagy ikerionos formákat, hogy a tisztítás következő lépéseit ne befolyásolják, illetve a fehérje aktivitására várhatóan ne legyenek hatással. Az SQR típusú fehérjék szolubilizálására leggyakrabban alkalmazott detergens az N-dodecil $\beta$-d-maltozid (DDM).

Az SqrD és SqrF fehérjéket termelő T: roseopersicina törzsekből membrán frakciót izoláltam, amelyet 0,1 és 1\% DDM detergenssel kezeltem 1 órán át. Az elegyek ultacentrifugálása után kapott szolubilis fehérjéket tartalmazó felülúszókból tisztítottam a fehérjéket. A kezelés után keletkezett 1\% DDM tartalmú UC-felülúszó sötét piros, míg a $0,1 \%$ detergens koncentrációjú minta esetében halvány rózsaszínes volt (17. ábra) mindkét fehérjetermelő sejtminta esetén. Az SqrD fehérjét nem, de az SqrF-et mind a két koncentrációban alkalmazott DDM detergens képes volt felszabadítani. Így a felülúszó frakciókból sikerült SqrF fehérjét tisztítanom a StrepII peptidet kötő affinitás kromatográfiával (IBA Gmbh.) (17. ábra).
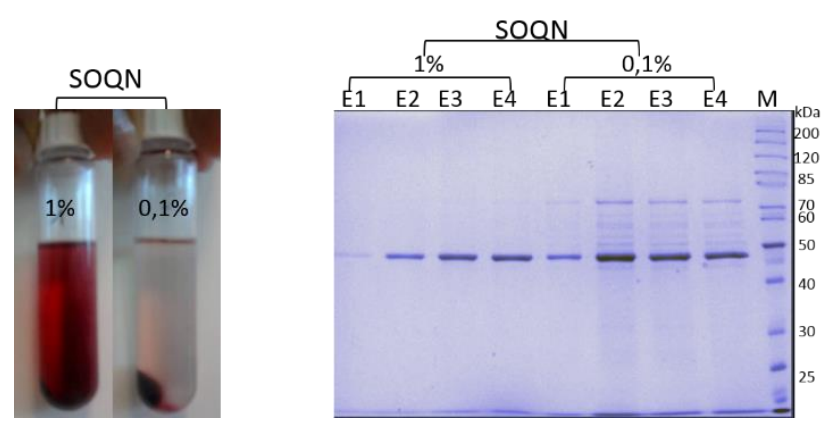

17. ábra: SOQN membrán frakció kezelés utáni UC-felülúszók, illetve ezen frakciókból való elúciós frakciók SDS-PAGE gélképe. E1-4: első-negyedik elúciós frakció 
A fehérje tisztítás eredményeként kapott SqrF elúciós frakciók abszorbancia spektruma azonban azt mutatta, hogy a kimutatási határértéket éppen elérő fehérje mennyiséget tartalmazzák, továbbá mindkét minta a membránban található fotoszintetikus pigmentek jelenlétére utaló fényelnyelési csúcsokat mutatott. Tehát az alkalmazott különbözö koncentrációjú DDM ugyan szolubilizálta a rekombináns SqrF fehérjét a membránból, azonban nagyon kis mennyiségben és az elúciós frakciók feltételezhetően a membrán darabokban lévő fotoszintetikus pigmentekkel szennyezettek voltak, ami miatt a tisztított fehérjék további biokémiai és biofizikai jellemzésre nem voltak alkalmasak.

Ezért további detergensek alkalmazhatóságát vizsgáltam meg a C- vagy N-terminálison affinitás peptiddel ellátott $\mathrm{SqrD}$ és $\mathrm{SqrF}$ fehérjék felszabadítására. Kísérleteim során vizsgáltam a Triton-X 100 (0,1; 1\%), Triton-X $114(0,1 ; 1 \%)$, Tween 20 $(0,1 \%)$, Thesit $(1 ; 2 ; 4 \%)$, LDAO $(0,1 ; 0,75 \%)$ szolubilizáló képességét. Az általam használt, felsorolt detergensek önállóan illetve kombinálva sem voltak képesek az SqrD fehérjéket egyáltalán, az SqrF fehérje variánsokat pedig nagy mennyiségben felszabadítani. Ezenfelül az UC-felülúszókból affinitás kromatográfia utáni SqrF elúciós frakciók fotoszintetikus pigmentekkel szennyezettek voltak, mely miatt a tisztított fehérje minták ezekben az esetekben sem voltak használhatóak további biokémiai mérésekhez.

Membránhoz kapcsolt fehérjék felszabadítása kaotróp ágensek használatával is megvalósítható. Ezen sók képesek vizes oldatban a víz molekulák közötti hidrogén-kötést felbontani, a fehérjék szempontjából ez azt jelenti, hogy a hidrofób részekkel rendelkező fehérjék környezetükből (pl.: membrán frakció) kiszabadulva nem fognak kicsapódni, jobban megőrzik natív állapotukat. Ilyen ágens a nátrium-bromid, mely alkalmazásával a $R$. capsulatus-ból sikeresen szabadítottak fel a sejtmembránból és tisztítottak I. típusú SQR fehérjét [45].

Az előzőekben említettek alapján a rekombináns SQR fehérjéket tartalmazó membrán frakciókat $2 \mathrm{M} \mathrm{NaBr}$-al kezeltem. A keletkezett UC-felülúszók erősen pirosas színezetüek voltak, melyekből az SqrD fehérjével ellentétben sikeresen tisztítottam rekombináns SqrF fehérjét (18/A. ábra). A tisztított fehérje (E2 eluált fehérje minta) abszorbancia spektruma alapján elmondható, hogy nagyobb mennyiségben sikerült a sejtmembrán mintából felszabadítani és tisztítani a rekombináns fehérjét (18/B. ábra), mint a detergensek használatával. Azonban a spektrum számos abszorbancia csúccsal rendelkezik, ennek oka lehet, hogy a felülúszóban olyan kisebb membrán darabok is vannak, melyek pigmenteket és SqrF fehérjéket is tartalmaznak (18/C. ábra). Ezek a membrán 
darabok a fehérje által felkötődnek az affinitás oszlopra és az elúció során a tisztított fehérje mintába kerülnek.

A

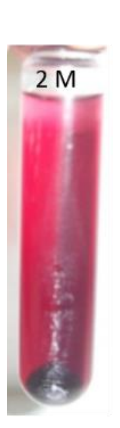

B

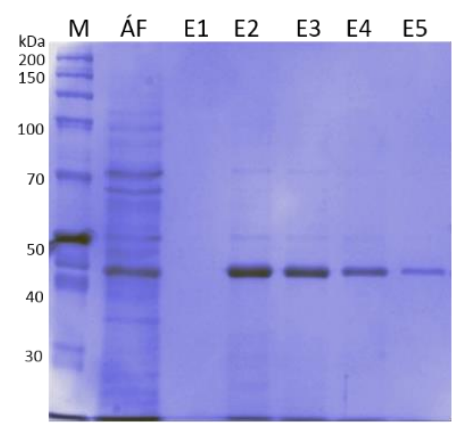

C

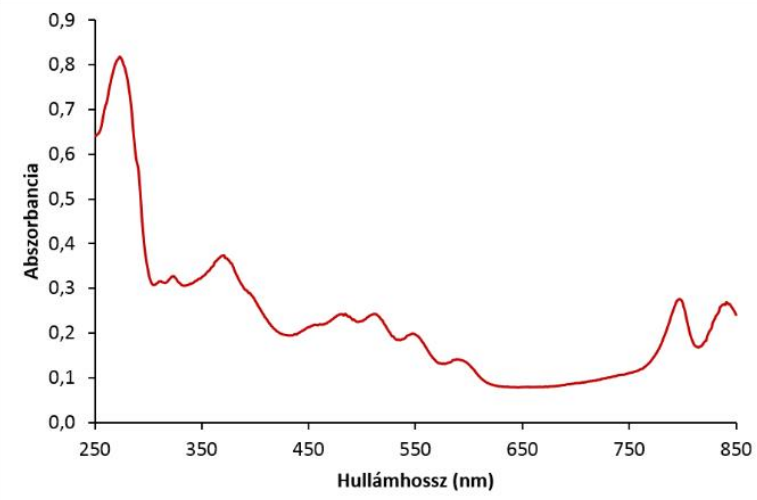

18. ábra: 2 M NaBr-al kezelt UC- felülúszó (A) illetve ebből származó elúciós frakciók SDS-

PAGE képe NSQNN törzs esetén (B), tisztított SqrF fehérje abszorbancia spektruma (C)

Fotoszintetikus pigmenteket nem tartalmazó elúciós frakciók létrehozása érdekében csökkentettem a membránból történő fehérje szolubilizálásra alkalmazott $\mathrm{NaBr}$ koncentrációt 1,5 M-ra, továbbá megemeltem az ultracentrifugálás erejét 100000xg-ről 200000xg-re. A fehérje tisztítási módszer ezen váloztatásainak eredményeként a membrán kezelés utáni UC-felülúszóból (19/A. ábra) történt fehérje tisztítás a korábbiaknál nagyobb mennyiségü, jó minőségü fehérjét eredményezett (19/B. ábra). Az elúciós frakció abszorbancia spektruma is mutatja, hogy a tisztított fehérje minta pigmenteket nem tartalmaz, nincsenek a membrán frakcióban található fotoszintetikus pigmentek jelenlétére utaló elnyelési maximumok (19/C. ábra). 
A

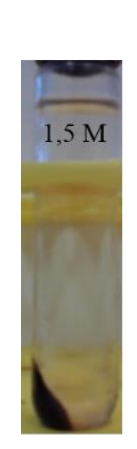

B

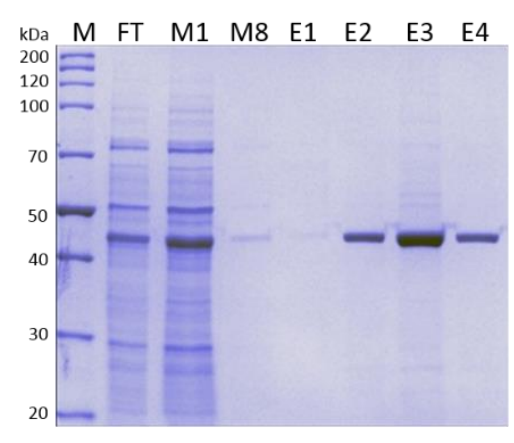

C

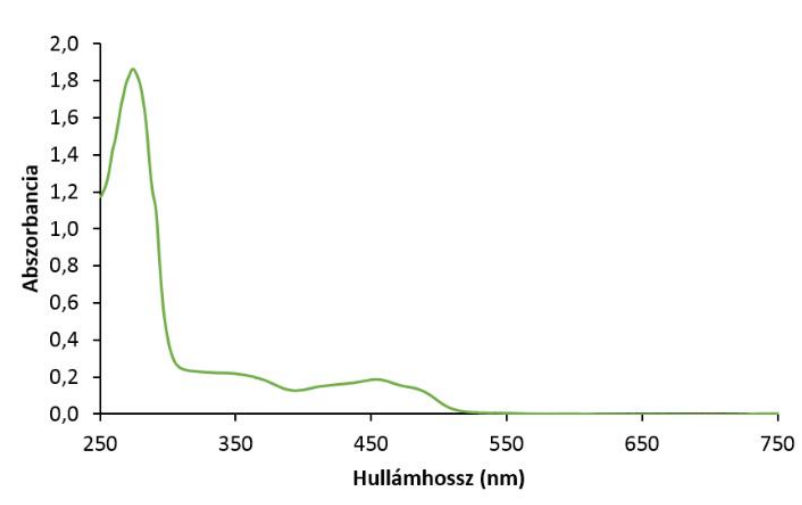

19. ábra: 1,5 M NaBr-al kezelt UC-felülúszóból (A) készült tisztítási frakciók SDS-PAGE képe (B), tisztított SqrF fehérje abszorbancia spektruma (C)

Azonban a kifejlesztett metódus ismétlései közben arra lettem figyelmes, hogy a membrán kezelése után a felülúszó teljessége nem volt mindig pigment-mentes (20. ábra), ezért a végső fehérje kihozatal megjósolhatatlan volt, hiszen csak a változó térfogatú, pigmenteket nem tartalmazó felülúszóból lehetett teljesen tiszta formában az SqrF fehérjét tisztítani. Ezért a tisztítási lépéseket tovább kellett fejleszteni.

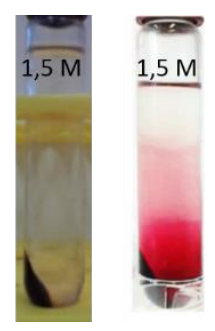

20. ábra: 1,5 M NaBr-al kezelt membrán frakciók UC-felülúszóinak változatos pigment tartalma.

A Gram-negatív baktériumokban található SQR típusú fehérjék a belső sejtmembrán periplazmatikus oldalához kapcsoltak, tehát feltételezésem szerint a $T$. roseopersicina sejtekben is az SqrD és SqrF a belső membrán külső oldalához kapcsolódik. A membrán ezen oldala nehezebben elérhető a kaotróp sók számára a vastag peptidoglükán réteg és a külső sejtmembrán miatt. A NaBr-al történő hatékonyabb fehérje felszabadítás elérése érdekében változtattam a sejtek feltárási módszerén. A fehérjetermelés céljára felnövesztett nagy térfogatú T. roseopersicina kultúrákból összegyüjtött NSQNN sejteket először lizozim tartalmú periplazmatizáló oldatban szuszpendáltam fel, ellentétben az eddigi lépéssel, ahol TBS oldatban vettem fel a sejteket (21. ábra A oszlop). A lizozim meglazítja a külső és belső 
sejtmembrán réteg közti peptidoglükán lemezt, majd a periplazmát eltávolítva szferoplast sejteket állítottam elő (21. ábra B oszlop), melyeket az eddigiekben is alkalmazott szonikálással tártam fel és választottam szét citoplazma illetve membrán frakcióra. Ezzel a fejlesztéssel több fehérjét sikerült szolubilizálni, ami alapján nagyobb mennyiségü fehérjét sikerült tisztítanom.

A sejtmembránt alkotó kettős lipidréteg stabilitásáért felelős egyik tényező a kétértékű kationok jelenléte. A membrán szerkezetének lazítása érdekében a $\mathrm{NaBr}$ kezelés előtt bevezettem egy 10 mM EDTA oldattal való inkubálás lépést (21. ábra C oszlop), mely eredményeként a membránt stabilizáló ionok lekötése által a $\mathrm{NaBr}$ hatékonyabban képes fehérjéket felszabadítani a sejtmembránból.

Látható, hogyha mindkét fejlesztési lépést egyszerre alkalmaztam (21. ábra D oszlop), a kezdeti tisztítási protokoll fehérje kihozatalához képest közel nyolcszor több fehérjét sikerült tisztítanom (21. ábra jobb oldali diagram).
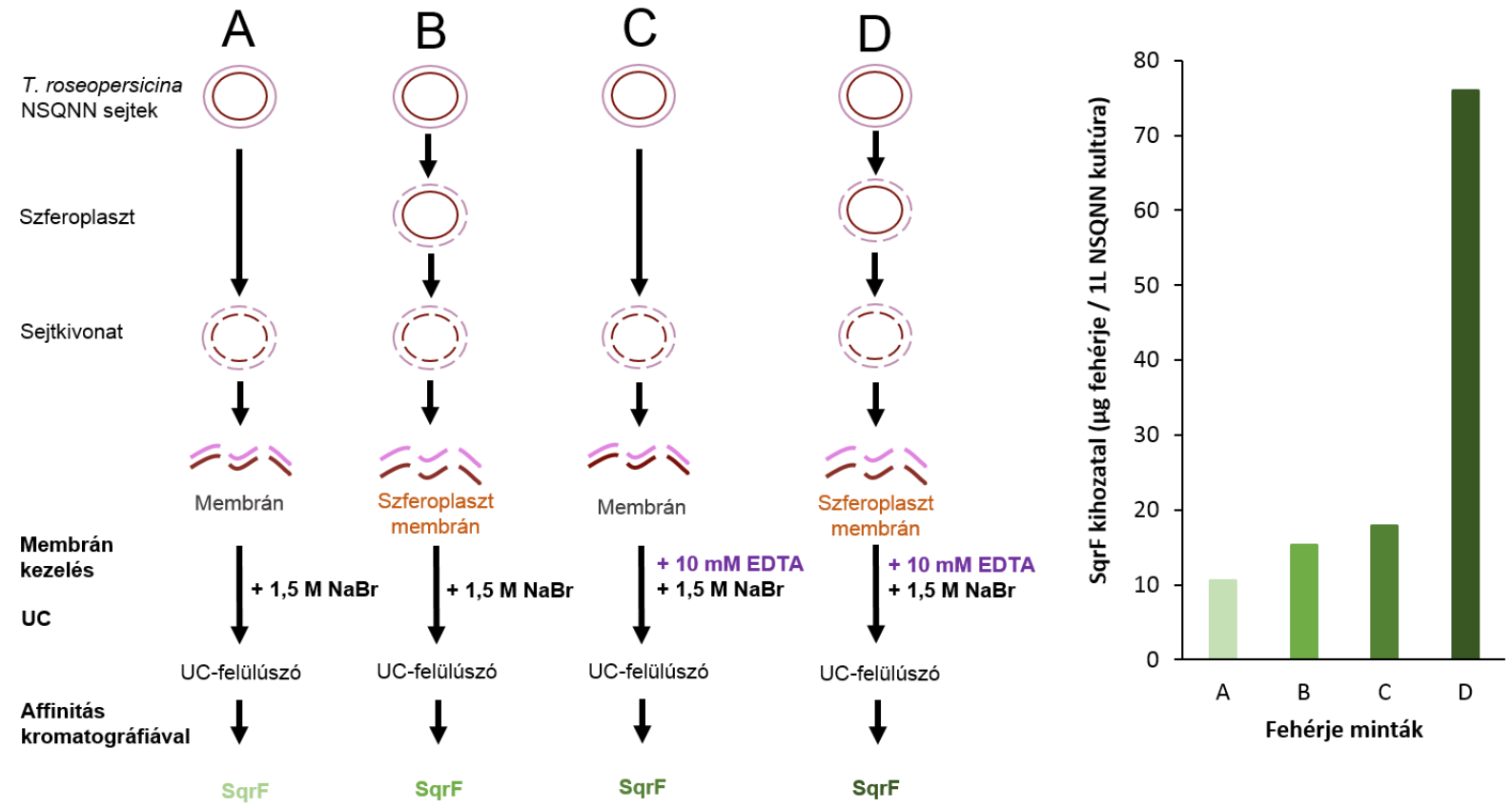

21. ábra: SqrF fehérje tisztítás kiindulási és fejlesztett módszerei, valamint a módszerekkel elért fehérje kihozatalok

Következő lépésként a fotoszintetikus pigmenteket is tartalmazó UC felülúszó pigment-mentesítését kellett megoldanom, mivel a membrán kezelése utáni felülúszó csak azon részét lehet fehérje tisztításra felhasználni, amely nem tartalmaz pigmenteket. 
Vélhetően az alkalmazott 1,5 M koncentrációjú nátrium-bromidot tartalmazó közeg miatt a fehérjékhez kötődö kisebb membrán darabok képtelenek voltak leülni az ultracentrifugálás során. A probléma megoldására a kezelés utáni pigmenteket tartalmazó UC felülúszó $\mathrm{NaBr}$ koncentrációját hígítással csökkentettem 1 M-ra, majd a hígított elegyet ultracentrifugáltam. Látható, hogy a második centrifugálási lépésben keletkezett felülúszó pigment mentes lett, viszont ezen frakcióból való fehérjetisztítás kihozatala visszaesett a felülúszó közel egyharmadát adó csak pigment-mentes részből tisztított fehérje mennyiségéhez képest (22. ábra).

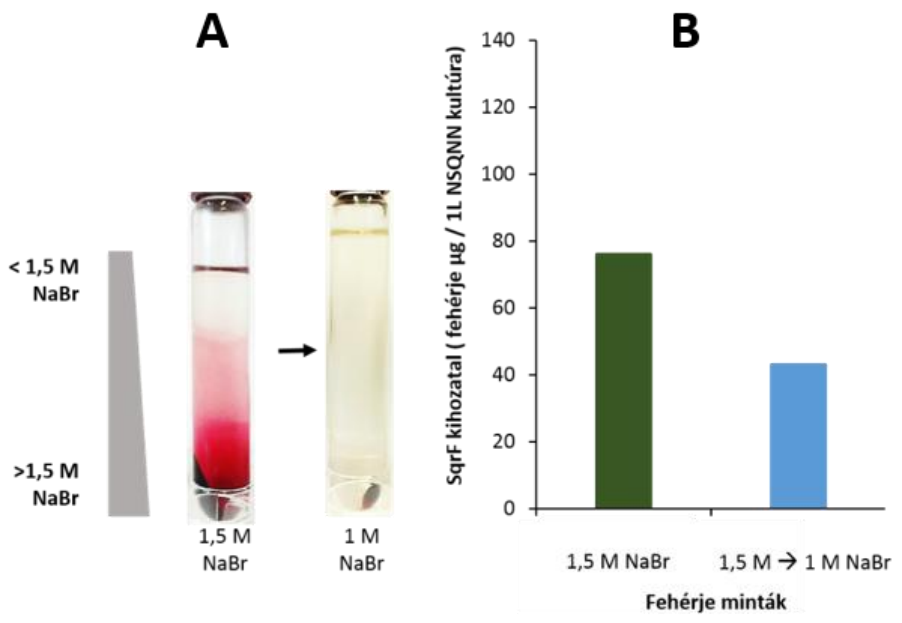

22. ábra:1,5 M NaBr-dal kezelt membrán frakció UC-felülúszó képe a hígítás előtt és után (A), illetve a pigmenteket nem tartalmazó és pigmentektől mentesített UC-felülúszó frakciók fehérjekihozatala (B)

Ennek oka lehet, hogy a lecsökkentett $\mathrm{NaBr}$ koncentráció alacsonynak számít a felszabadított fehérjék számára, ezért az UC felülúszóban jelenlevő membrán darabokhoz kapcsolódnak és velük az ultracentrifugálás során képződő csapadékba (membrán darabok) jutnak. Ezért meg kellett találnom azt a minimális mértékű $\mathrm{NaBr}$ koncentráció csökkentést, mely a membránból felszabadított fehérjéket még oldatban képes tartani, azonban hatására a membrán kezelés során keletkező kisebb membrán darabok csapadékot tudjanak képezni.

A megfelelő hígításnak a 1,5 M-ról 1,4 M-ra történő bizonyult, mivel ezen UCfelülúszóból megközelítőleg hétszer több fehérjét tudtam tisztítani, mint a 1,5 M-ról 1 M-ra hígított felülúszókból (23. ábra). 


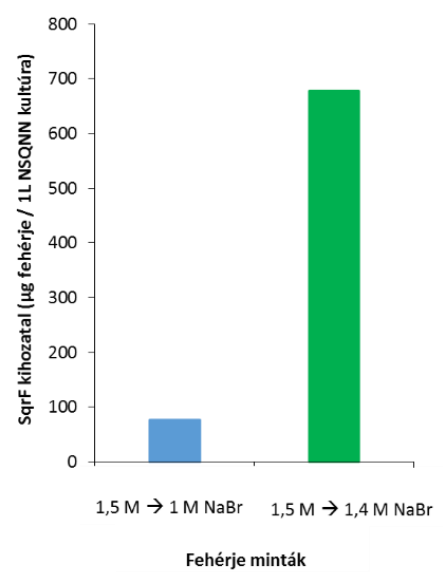

23. ábra: Különböző hígítási lépéseket alkalmazó fehérje tisztítási metódusok tisztított SqrF fehérje kihozatala

A bemutatott eredmények alapján kifejlesztettem a membránhoz kapcsolt SqrF fehérje tisztítására alkalmas protokollt, mely a következő lépésekből áll: a sejtekből szferoplasztokat készítek, majd ezek feltárását követően membrán frakciót izolálok. A membrán kezelés két lépésből: elsőként EDTA, majd $\mathrm{NaBr}$ oldattal történő inkubálásból áll. A szolubilizált fehérjéket tartalmazó vélhetően fotoszintetikus pigmentekkel szennyezett UC-felülúszót $\mathrm{NaBr}$ koncentráció hígítással pigment mentesítem, majd affinitás kromatográfiával tisztítom a StrepII peptiddel ellátott rekombináns SqrF fehérjét (24. ábra).

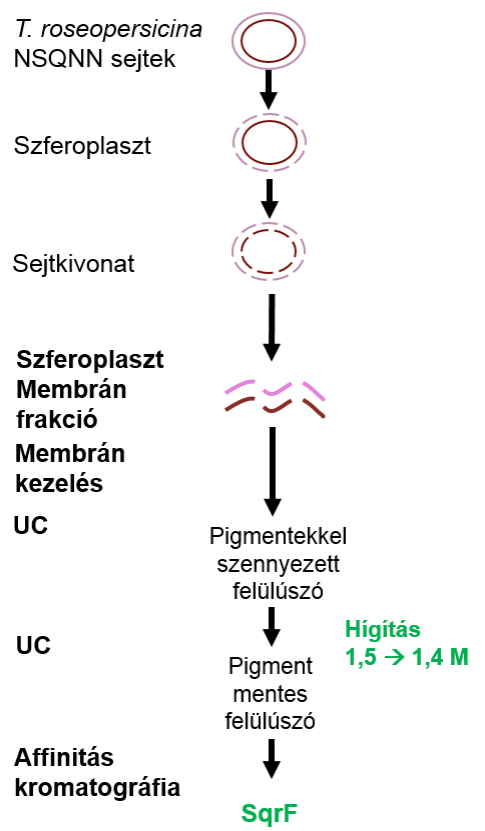

24. ábra: Rekombináns SqrF fehérje tisztítási metódus lépései 
Követve a fenti tisztítási lépéseket a tisztított fehérje minta biokémiai, spektroszkópiai vizsgálatokra alkalmas.

\subsection{A tisztított SqrF fehérje jellemzése, tulajdonságai}

\subsubsection{Az SqrF fehérje gélelektroforézis vizsgálata}

Az SQR típusú fehérjék monotipikus fehérjék, mérettartományuk 40-55 kDa. Kristályszerkezet alapján, továbbá kísérletesen is igazolták, hogy az SQR fehérjék képesek dimer és trimer asszociációs formát felvenni [67,68].

A T. roseopersicina tisztított SqrF fehérje mintát SDS-poliakrilamid gélen futtatva egy diszkrét sávot ad $\sim 4$ kDa magasságban (25/A. ábra). Natív grádiens gélen való futtatás után StrepII peptid elleni ellenanyag használatával, Western analízissel, vizsgáltam az SqrF fehérje oligomerizációs hajlamát, mely során három különálló sávot azonosítottam, melyek feltételezhetően a monomer, dimer és trimer formáknak feleltethetőek meg (25/C. ábra).

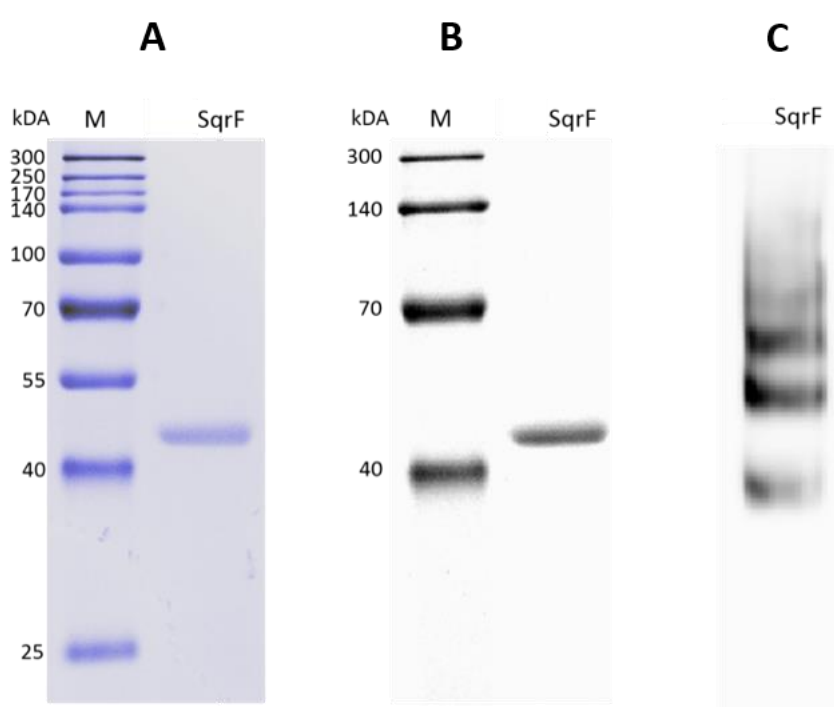

25. ábra: Tisztított SqrF SDS-PAGE képe (A), festetlen; UV-val megvilágított SDS-PAGE képe (B), natív grádiens futtatás utáni Western analízis képe (C) 


\subsubsection{SqrF fehérje spektroszkópiai vizsgálata}

Szulfid kinon oxidoreduktáz típusú fehérjék közös jellemzője a FAD tartalom. A kofaktor jelenlétét a fehérjék abszorbancia spektrumában jelenlévő jellegzetes fényelnyelési csúcsok mutatják 360 és 450 nm hullámhossznál melyek az oxidált állapotú FAD molekulák jellemző fényelnyelési maximumai.

Annak érdekében, hogy megvizsgáljam a tisztított SqrF FAD tartalmát, meghatároztam a fehérje UV-Vis abszorbancia spektrumát, melyen azonosítható 360 illetve 450 nm-nél egy egy magasabb fényelnyelési csúcs, mely oxidált állapotú FAD kofaktor tartalomra utal. Ezt támasztja alá a fehérje fluoreszcens emissziós spektruma is, ugyanis a FAD kofaktor $450 \mathrm{~nm}$ hullámhosszon történő gerjesztése esetén a kibocsátott fény spektrumában 520 nm-nél található egy csúcs (26. ábra).

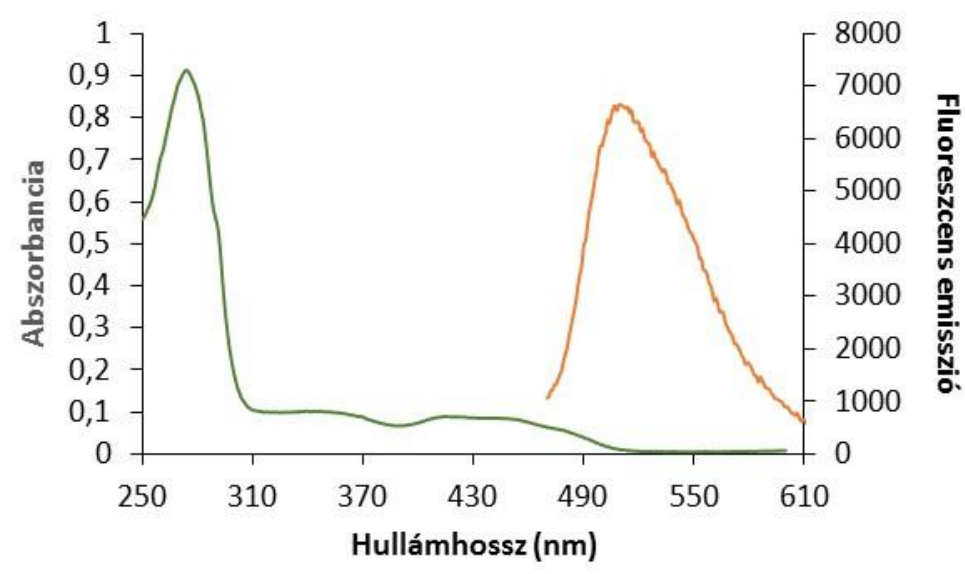

26. ábra: Tisztított SqrF fehérje abszorbancia (zöld) és fluoreszcens (narancssárga) spektruma, melyek igazolják a fehérjében lévő FAD kofaktor tartalmat

Az SqrF fehérje abszorbancia spektrumából, a FAD extinkciós koefficiensének (11,300 $\mathrm{M}^{-1} \mathrm{~cm}^{-1} 450 \mathrm{~nm}$-en) [90] felhasználásával kiszámolható, hogy 1 mol tisztított rekombináns SqrF fehérje 0,74 \pm 0,14 mol FAD-ot tartalmaz.

SQR típusú fehérjék bizonyos csoportjában kovalensen, más típusba tartozó fehérjékben pedig nem-kovalens módon kötött a FAD kofaktor. VI. típusú SQR fehérjék FAD kötésének mivoltáról nincs információ, ezért megvizsgáltam a T. roseopersicina SqrF fehérjében lévő FAD kötési módját. Ehhez a tisztított fehérje mintát az SqrF fehérjék szerkezetének fellazítása céljából forró metanolban inkubáltam vagy $5 \%$ triklórecetsavval kezeltem. A fehérje mindkét esetben denaturálódott, centrifugálással leülepíthető csapadékot 
képzett, mely sárgás szinezete arra utalt, hogy a FAD nem szabadult fel a denaturált fehérjéböl, kötődik hozzá (27/B. ábra). A centrifugálás után kapott felülúszó oldat spektrumában nem találhatóak FAD tartalomra utaló elnyelési csúcsok, melyek a kontrollként alkalmazott FAD oldat spektrumában azonosíthatóak (27/A. ábra). Ezek alapján elmondható, hogy az SqrF fehérje kovalensen köti a FAD kofaktort. Ezt támasztja alá a tisztított SqrF festés előtti, UV-val megvilágított SDS-PAGE képe (25/B. ábra), melyen látható, hogy az SqrF fehérje sáv fluoreszkál, tehát a FAD kofaktor a fehérjéhez kovalens módon kötött.

A

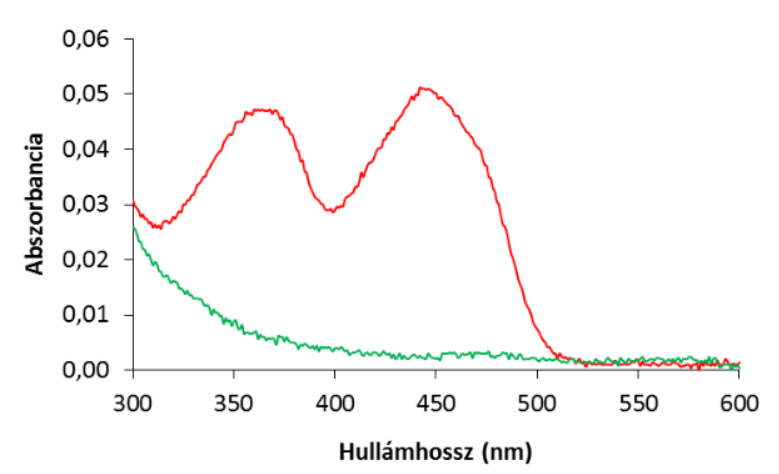

B

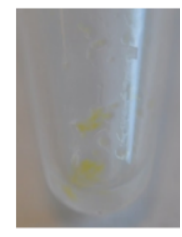

27. ábra: Forró metanolban inkubált kontrol FAD oldat (piros); denaturált SqrF (zöld) felülúszó abszorbancia spektruma (A), denaturált SqrF fehérje centrifugálás utáni csapadék frakció képe (B)

Az SQR fehérjék müködéséhez elengedhetetlen a FAD kofaktor elektron fogadó és átadó képessége. Az oxidált és redukált FAD jellegzetesen eltérő abszorbancia spektrummal rendelkezik.

Ezért annak érdekében, hogy megállapítsam, hogy az SqrF fehérjében lévő prosztetikus csoport redox aktív-e, a $10 \mu \mathrm{M}$-nyi tisztított SqrF mintához frissen készített $1 \mathrm{mM}$ nátrium-dithionitot pipettáztam, mely egy általánosan használt erős redukálószer. Az elegy UV-Vis spektrumát nyomon követve a hozzáadott redukálószer hatására a fehérje spektruma megváltozik, az abszorbancia spektrum esetén a 450 nm-nél lévő csúcs eltűnt, az emissziós spektrum esetében pedig az 520 nm-nél lévő csúcs számottevően lecsökken. Mindezen változások a tisztított fehérjében lévő FAD-nak a kezelés hatására végbemenő redukálódására utalnak. Az SqrF visszaoxidálásához elektronakceptorként $100 \mu \mathrm{M}$ 
koncentrációjú durokinont pipettáztam a redukált fehérje elegyhez, mely hatására a fehérje a kezdeti oxidált állapotába került vissza (28/A. ábra).
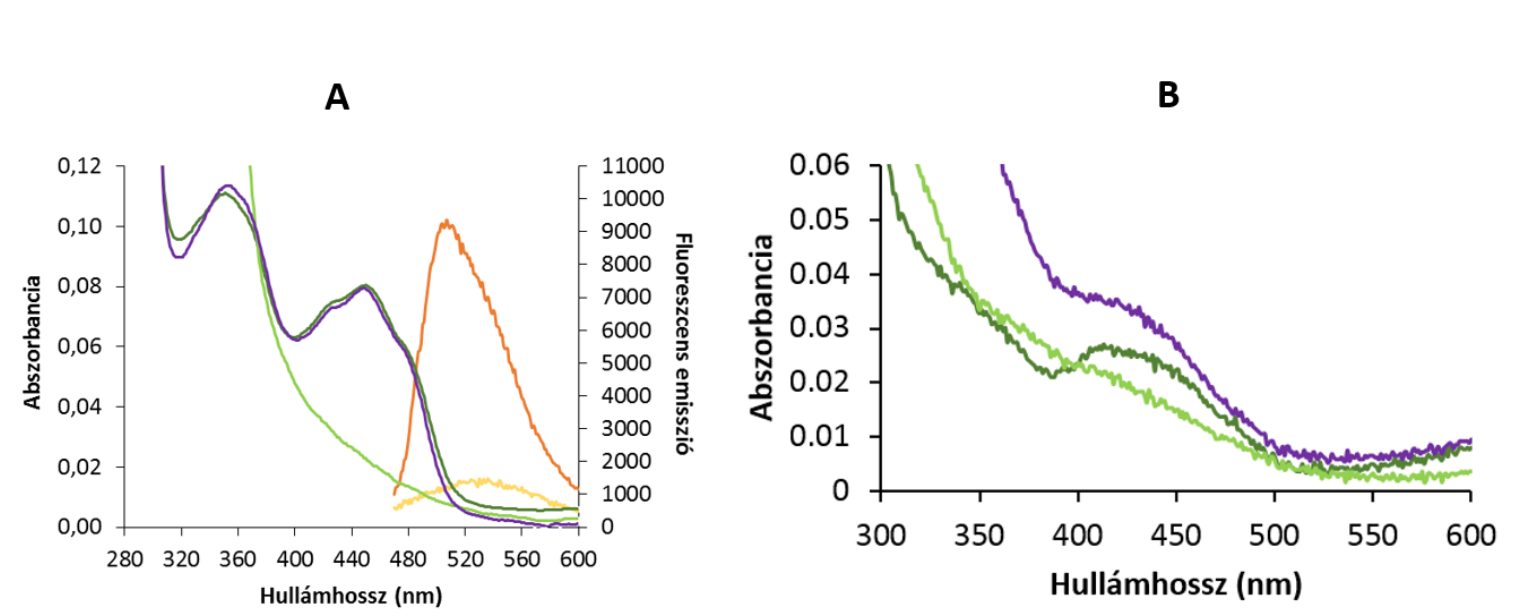

28. ábra: Oxidált (sötétzöld; narancs); Na-dithionittal redukált (világoszöld; sárga) és visszaoxidált (lila) SqrF fehérje abszorbancia és fluoreszcens spektruma (A), oxidált (sötétzöld); Na-szulfiddal redukált (világoszöld és visszaoxidált (lila) SqrF fehérje abszorbancia spektruma (B)

A fehérje nem csak mesterséges redukálószer hatására képes redukált állapotba kerülni, hanem a természetes szubsztrátja, a szulfid hatására is (28/B. ábra). Összességében a fehérje képes redukált állapotba kerülni mind dithionit mind szulfid hatására, melyek elektrondonorként funkcionálnak, továbbá a hozzáadott durokinon, mint elektronakceptor hatására a fehérje oxidálódik.

\subsubsection{Az SqrF fehérje enzimatikus jellemzése}

\subsubsection{1. $\quad$ A tisztított SqrF fehérje aktivitása}

Ahhoz, hogy egy fehérje az SQR családba sorolható legyen, igazolni kell, hogy szulfid függő kinon redukáló aktivitással rendelkezik. Az enzim katalízisét az elektronakceptor, a kinon redukáltsági szintjének követésével lehet vizsgálni spektrofotométer segítségével. Ha a fehérje képes kinont redukálni a szulfid oxidáció során keletkező elektronokkal, az elektronakceptor abszorbanciája csökken. Tehát megvizsgáltam, 
hogy az általam tisztított SqrF fehérje rendelkezik-e szulfid függő kinon redukáló aktivitással.

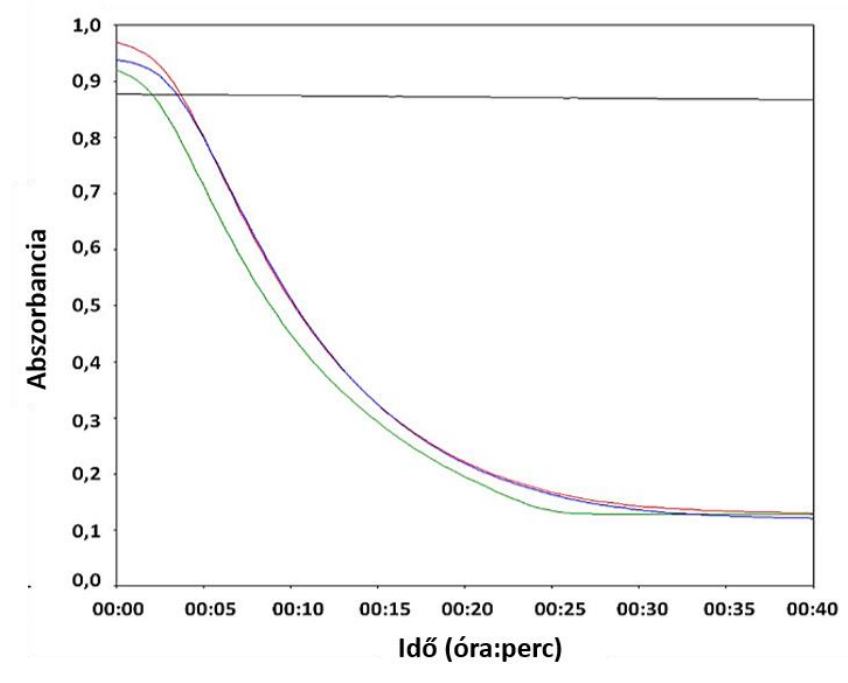

29. ábra: Tisztított SqrF enzim szulfid függő durokinon redukáló aktivitása. SqrF mintát tartalmazó reakciók (piros, zöld, kék), enzim mentes reakció (fekete)

A kontrol reakcióelegy abszorbancia változásának görbéjéből látszik, hogy enzimtől független háttér reakció az elektrondonor és akceptor között nem detektálható, tehát a szulfid önmagában nem képes a durokinont redukálni. Azonban, ha SqrF enzim is van a reakcióelegyben, akkor a kinetika alapján elmondható, hogy egy folyamatosan gyorsuló fázis után a reakció eléri maximum sebességét, majd lassulni kezd, amíg a jelen levő kinon mennyiség teljesen elredukálódik, és a folyamat leáll (29. ábra). A reakciókinetika alapján felmerül a lehetőség, hogy az SqrF enzimben valamiféle aktiválódás megy végbe a reakció elején mialatt felgyorsul a katalízis.

Továbbiakban különböző típusú kinonokkal határoztam meg az SqrF aktivitását, mivel az SQR fehérjék különféle kinonokhoz változó affinitással bírnak. A felhasznált kinonok két nagyobb csoportra oszthatóak: ubikinon típusúakra (durokinon; decilubikinon; ubikinon-10) és menakinon típusba tartozókra (menadion; menakinon-4; menakinon-7). 


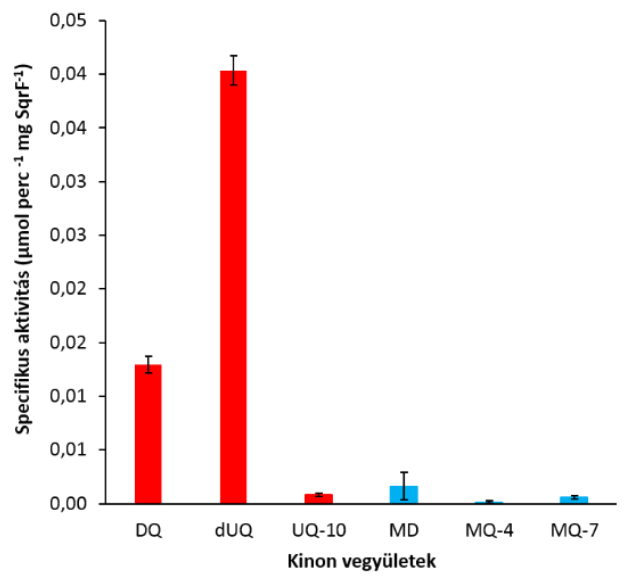

30. ábra: Az SqrF enzim különböző kinonokkal mérhető aktivitása. DQ: durokinon; dUQ: decilubikinon; UQ-10: ubikinon-10; MD: menadion; MQ-4: menankinon-4; MQ-7: menakinon-7

Az SqrF a legnagyobb aktivitást a decilubikinon jelenlétében mutatta, továbbá egyértelmủen kimutatható, hogy az enzim az ubikinon típusú kinonokat részesíti előnyben, a menakinon típusú kinonokkal nagyon alacsony aktivitást mutatott (30. ábra).

Ezt követően feltettem a kérdést, hogy a kinonokon kívül van e más jellegü molekula, mint elektronakceptor, amelynek képes lenne átadni az SqrF a szulfidról származó elektronokat. Kísérleteket végeztem szulfid függő citokróm c; $\mathrm{NAD}^{+} ; \mathrm{NADP}^{+}$redukció kimutatására, azonban a tisztított enzim egyik esetben sem volt képes katalizálni a kérdéses reakciót.

\subsubsection{2. $\quad \underline{\text { SqrF enzim aktivitásának } \mathrm{pH} \text { függése }}$}

Az enzimek fontos jellemzője az aktivitásuk pH függése, melyet megvizsgáltam az SqrF fehérje esetén mind dUQ és DQ jelenlétében is. Látható, hogy mindkét kinon esetében az enzim aktivitásának pH optimuma pH=8,00 (31. ábra), továbbá megfigyelhető, hogy az enzim szük $\mathrm{pH}$ optimummal rendelkezik, $\mathrm{pH}=6,00$ és $\mathrm{pH}=9,50$ pufferben a $\mathrm{pH}$ optimumon mért aktvitás értékhez képest csak 5-15\%-os aktivitás volt tapasztalható. 
A

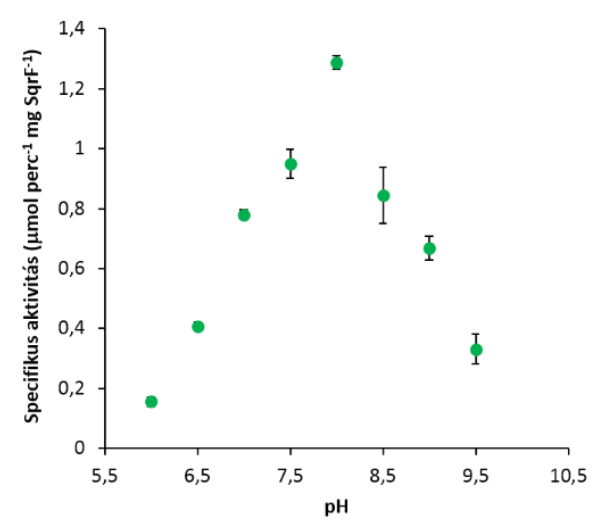

B

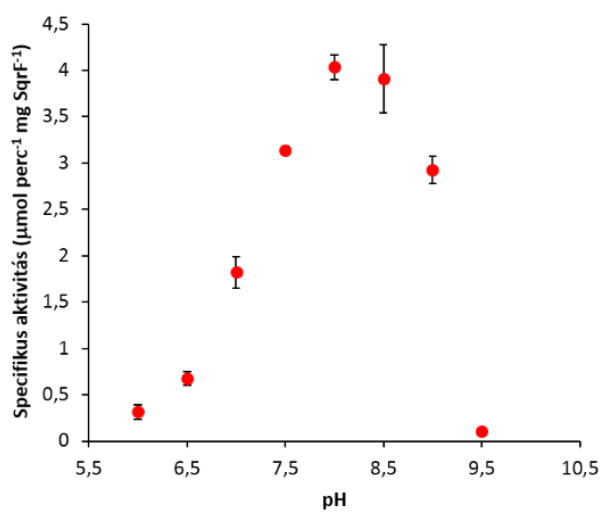

31. ábra: Az SqrF DQ (zöld) illetve dUQ (piros) redukáló aktivitásának pH függése

\subsubsection{3. $\quad$ Az SqrF enzim aktivitásának hőmérsékletfüggése, aktiválási energiái}

Következő lépésben az SqrF aktivitásának hőmérsékletfüggését vizsgáltam DQ és dUQ elektronakceptor használatával. DQ szubsztrát alkalmazása esetén $55{ }^{\circ} \mathrm{C}$-ig folyamatosan emelkedő aktivitással rendelkezik az enzim, ahol eléri aktivitásának maximumát. Ezután egy hirtelen bekövetkező drasztikus csökkenés tapasztalható, $56{ }^{\circ} \mathrm{C}$-on az aktivitás közel 50\%, $58{ }^{\circ} \mathrm{C}$-on pedig már teljesen megszünik. Decilubikinon használata mellett az enzim a maximális aktivitását $45{ }^{\circ} \mathrm{C}$-on érte el, ezután folyamatos csökkenést mutatott (32. ábra).

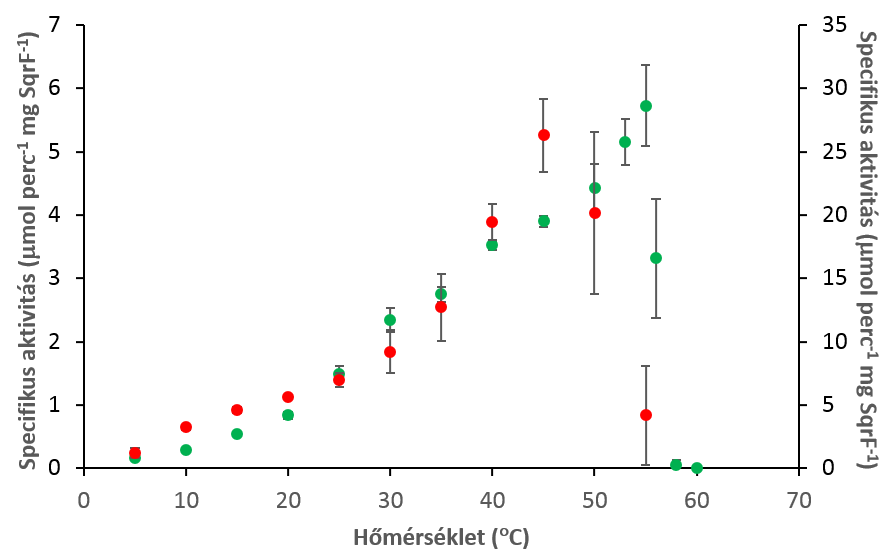

32. ábra: Az SqrF DQ (zöld) és dUQ (piros) redukáló aktivitásának hőmérsékletfüggése 
Az enzimek aktivitásának hőmérsékletfüggési méréseinek során meghatározott reakciósebességek exponenciálisan emelkedő tartományaira érvényes lehet az Arrheniusegyenlet, amely segítségével kiszámolható az enzim által katalizált reakció aktivációs energiája. Ezért logaritmizálással megvizsgáltam van e olyan szakasza az SqrF enzim aktivitás hőmérsékletfüggésének, amelyen exponenciális az összefüggés a hőmérséklet és az enzim aktivitás paraméterek közt.

Durokinon használatával mért enzimaktivitás hőmérsékletfüggési logaritmizált adataira két egyenes illeszthető, tehát a vizsgált hőmérséklet tartománynak két szakaszában is exponenciális összefüggés van a hőmérséklet és az enzim aktivitása közt. Decilubikinon alkalmazása mellett a $T$. roseopersicina fiziológiás hőmérsékletét is magába foglaló tartományban a kinon redukció sebességének függése a hőmérséklettől szintén exponenciális összefüggéssel írható le.

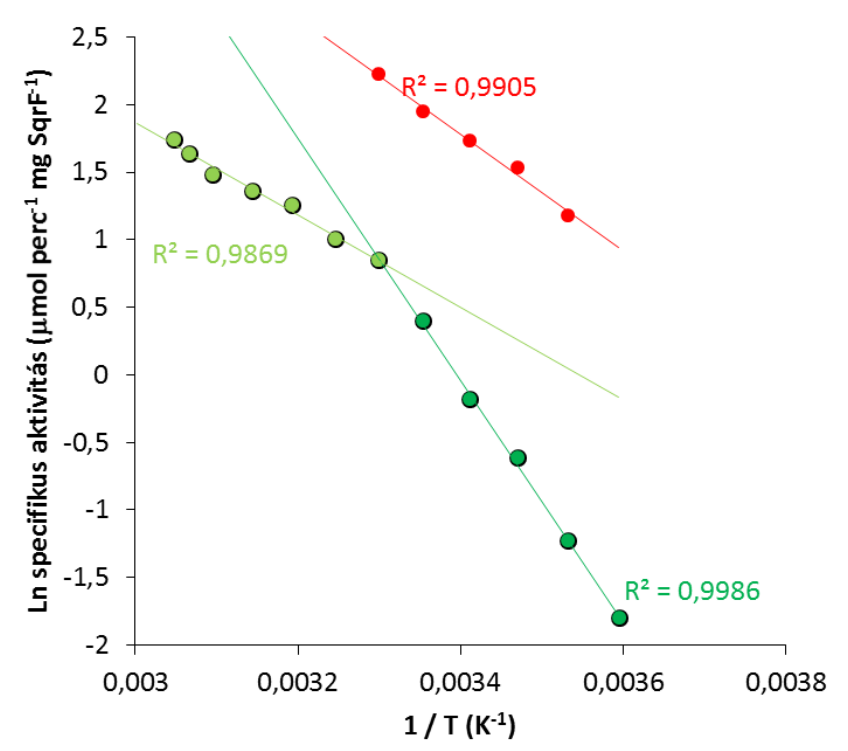

33. ábra: SqrF enzim DQ (zöldek) illetve dUQ (piros) redukáló aktivitás hőmérséklet függése Arrhenius-féle ábrázolásban

Az Arrhenius egyenlet (meredekség $\left.=-\mathrm{E}_{\mathrm{a}} / \mathrm{R}\right)$ és az egyetemes gázállandó $\left(\mathrm{R}=8,31 \mathrm{~J} \mathrm{~K}^{-1}\right.$ mol $^{-1}$ ) segítségével kiszámoltam az $\mathrm{SqrF}$ enzim kétféle kinon szubsztráttal történő reakcióinak aktivációs energiáját (33. ábra). A durokinon jelenlétében számolt aktivációs energia a fiziológiai hőmérséklet tartományban $73,6 \mathrm{~kJ} \mathrm{~K}^{-1} \mathrm{~mol}^{-1}$, míg a magasabb hőmérsékleteknél 28,3 $\mathrm{kJ} \mathrm{K}^{-1} \mathrm{~mol}^{-1}$, továbbá a dUQ alkalmazása mellett szintén a fiziológiás hőmérsékleti körülmények közt pedig $35,8 \mathrm{~kJ} \mathrm{~K}^{-1} \mathrm{~mol}^{-1}$. 


\subsubsection{4. $\quad \underline{\text { Az SqrF enzim hőstabilitása }}$}

Habár a T. roseopersicina növesztési hőmérséklete $25-28{ }^{\circ} \mathrm{C}$, a T. roseopersicina sejtekből tisztított SqrF termofil hőmérsékleti optimummal rendelkező enzim. Hőstabilitásának vizsgálata érdekében az SqrF enzimet a hőmérsékleti optimuma feletti hőmérsékleteken inkubáltam változó ideig, majd megmértem szulfid függő durokinon redukáló aktivitását $25^{\circ} \mathrm{C}$-on.

Az SqrF enzim nagyon stabil $50{ }^{\circ} \mathrm{C}$-on, 1 órás inkubálás után is megőrizte aktivitását, míg az $55{ }^{\circ} \mathrm{C}$-on inkubált minták enyhe aktivitáscsökkenést mutattak. A $60{ }^{\circ} \mathrm{C}$-on mérhető aktivitásával ellentétben, ha a fehérje mintát $60{ }^{\circ} \mathrm{C}$-on kezeltem 1 órán át, ezt követően is $50 \%$-os aktivitással rendelkezett, míg $65^{\circ} \mathrm{C}$ esetén már 10 perc inkubációt követően az enzim aktivitás a felére csökkent (34. ábra).

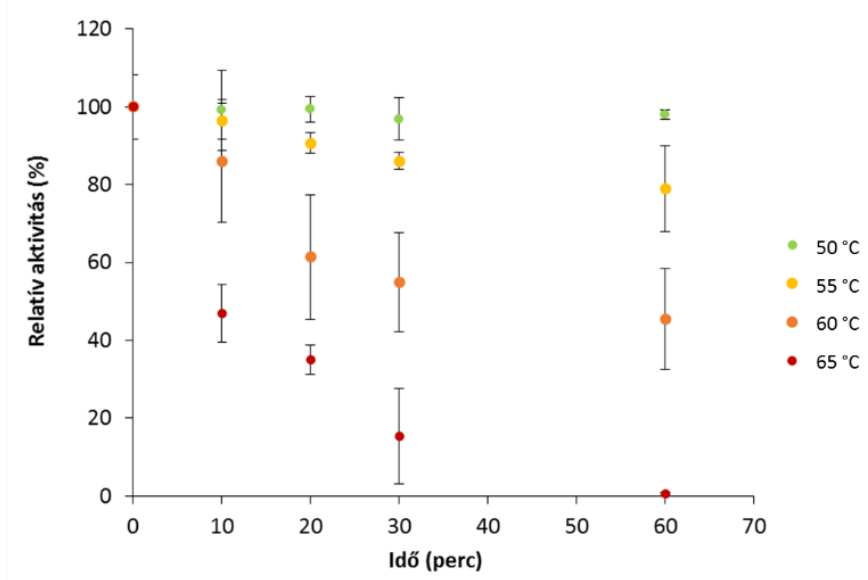

34. ábra: Az SqrF DQ redukáló aktivitás hőstabilitása különböző hőmérsékleten az idő függésében

\subsubsection{5. $\quad \underline{\text { Az SqrF enzim kinetikai paraméterei }}$}

Meghatároztam az SqrF enzim aktivitásának szulfidtól, mint elektrondonortól, továbbá durokinontól és decilubikinontól, mint elektronakceptoroktól való függését. 

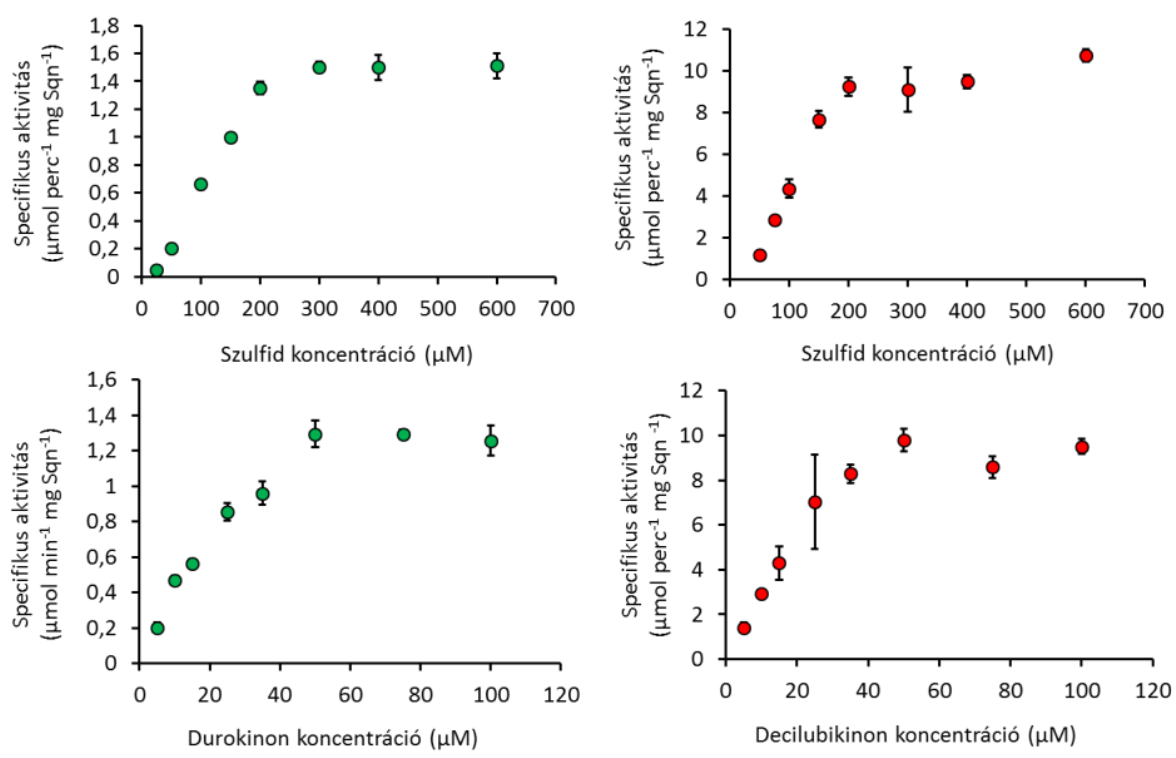

35. ábra: SqrF enzim aktivitásának szulfid, durokinon és decilubikinon koncentrációtól való függése

Ezen adatokból nem-lineáris regressziós illesztés alapján Matlab program segítségével kiszámoltam az SqrF enzimre vonatkozó $\mathrm{K}_{\mathrm{m}}, \mathrm{V}_{\mathrm{max}}, \mathrm{k}_{\mathrm{cat}}$ értékeket mindkét ko-szubsztrát esetén (2. táblázat).

\begin{tabular}{lllllll}
\hline Elektronakceptor & $\begin{array}{l}\mathrm{V}_{\max } \\
\left(\mu \mathrm{mol} \mathrm{perc}^{-1} \mathrm{mg}^{-1}\right)\end{array}$ & $\begin{array}{l}\mathrm{K}_{\mathrm{cat}} \\
\left(\mathbf{s}^{-1}\right)\end{array}$ & $\begin{array}{l}\mathrm{K}_{\mathrm{m}}(\mathrm{Na} 2 \mathrm{~S}) \\
(\mu \mathrm{M})\end{array}$ & $\begin{array}{l}\mathrm{K}_{\mathrm{m}}(\mathrm{Kinon}) \\
(\mu \mathrm{M})\end{array}$ & $\begin{array}{l}\mathrm{K}_{\text {cat }} / \mathrm{K}_{\mathrm{m}} \\
\left(\mathrm{Na}_{2} \mathrm{~S}\right) \\
\left(\mu \mathrm{M}^{-1} \mathbf{s}^{-1}\right)\end{array}$ & $\begin{array}{l}\mathrm{K}_{\text {cat }} / \mathrm{K}_{\mathrm{m}} \\
(\mathrm{Kinon}) \\
\left(\mu \mathrm{M}^{-1} \mathbf{s}^{-1}\right)\end{array}$ \\
\hline Durokinon & $2,29 \pm 0,19$ & $1,64 \pm 0,14$ & $209 \pm 30$ & $27,4 \pm 2,5$ & 0,008 & 0,06 \\
Decilubikinon & $15,1 \pm 0,6$ & $10,9 \pm 0,4$ & $232 \pm 27$ & $24,5 \pm 6,4$ & 0,047 & 0,44 \\
\hline
\end{tabular}

2. táblázat: SqrF enzim aktivitásának kinetikai paraméterek

A szulfidra kapott $K_{m}$ értékek DQ vagy dUQ alkalmazásakor hasonlóak, továbbá az azonos szulfid koncentráció mellett számolt $\mathrm{K}_{\mathrm{m}}$ értékek a két vizsgált kinonra szintén

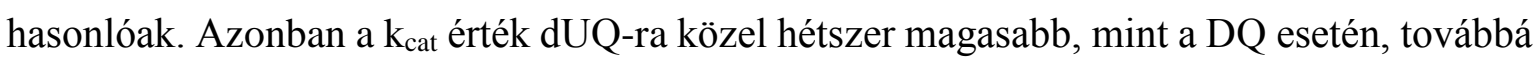
a $V_{\max }$ érték közel ötszörös a dUQ használatával, mint a DQ alkalmazása mellett. 


\subsubsection{Az SqrF enzim müködési mechanizmusa}

Az SQR típusú fehérjében található konzervált ciszteinek eszenciális vagy lényeges szerepet játszanak a katalízisben, melyet több csoport képviselőjénél kísérletesen igazoltak. Azonban a VI. típusnál eddig nem vizsgálták az enzim müködési mechanizmusát, és a fehérjében található cisztein aminosavaknak a katalitikus folyamatban játszott szerepét, ezért célom volt a $T$. roseopersicina $\mathrm{SqrF}$ fehérje ciszteinjeinek a fehérje müködésében betöltött szerepének meghatározása.

Az SqrF enzim esetében 3 konzervált ciszteint azonosítottam a 121., 272. és 332. pozícióban, továbbá a 49. ciszteint, ami csak a T. roseopersicina-ra jellemző. Paragi Gábor és munkatársai a $T$. roseopersicina SqrF fehérje térszerkezeti modelljét elkészítették az A. aeolicus SqrA enzimének röntgen krisztallográfiával meghatározott szerkezete alapján in silico homológia modellezéssel. A modell szerint az említett ciszteinekből 2 darab (C121, C332) az aktív centrumhoz közel, a FAD kofaktor izoalloxazin csoportjának két oldalán található. A másik kettő (C49, C272) a fehérje centrumától távol, az enzim felszínéhez közel, a fehérje két ellentétes oldalán helyezkedik el (36. ábra).

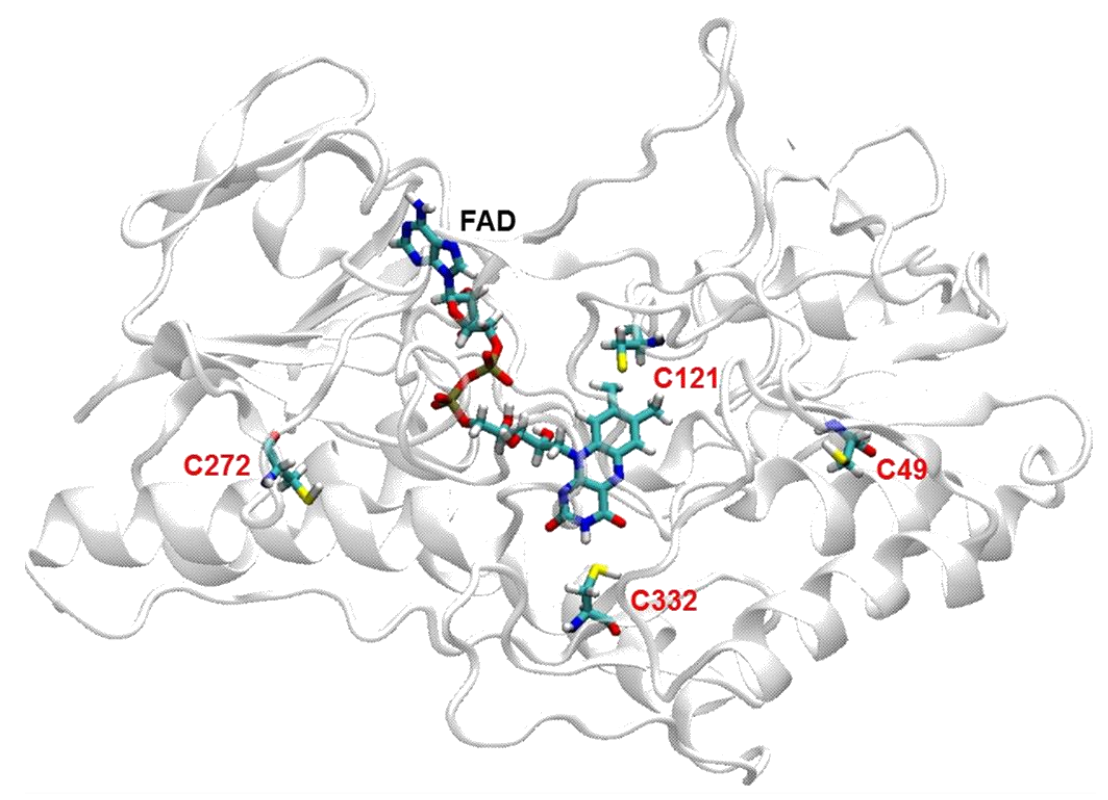

36. ábra: Az SqrF fehérje in silico térszerkezete és a ciszteinek elhelyezkedése

Az SqrF fehérjében található ciszteinek funcionális szerepének tisztázása érdekében irányított mutagenezissel azokat külön-külön alaninra változtattam át. Az egyes cisztein mutáns fehérje variánsokat kódoló géneket a helyspecifikus mutagenezis reakciót követően expressziós vektorba építettem. Ezeket konjugációval a vad típusú SQR fehérjéket nem 
termelö T. roseopersicina törzsbe jutattam, létrehozva a C49A; C121A; C272A; C332A T. roseopersicina törzseket, melyek fehérjetermelö képességét Western-analízis segítségével ellenőriztem (37. ábra).

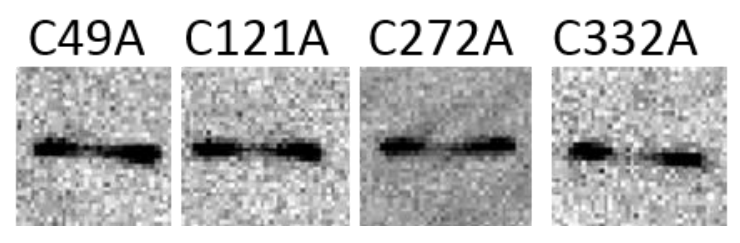

37. ábra: Cisztein mutáns SqrF fehérjéket termelő T. roseopersicina kultúra minták SDS-PAGE utáni Western hibridizációs képe

\subsubsection{1. $\quad$ SqrF fehérje variánsok gélelektroforézis vizsgálata}

A vad típusú SqrF fehérje esetében kidolgozott tisztítási eljárással sikeresen tisztítottam a mutáns fehérjéket. A tisztított fehérje minták összetételét SDS-PAGE segítségével állapítottam meg, mely alapján elmondható, hogy minden mutáns fehérjeváltozat mintája esetében egy sávot láthatunk 44 kDa magasságban, tehát az enzimek tisztasága közel 100\%-os, alkalmasak további biokémiai vizsgálatokra (38. ábra).

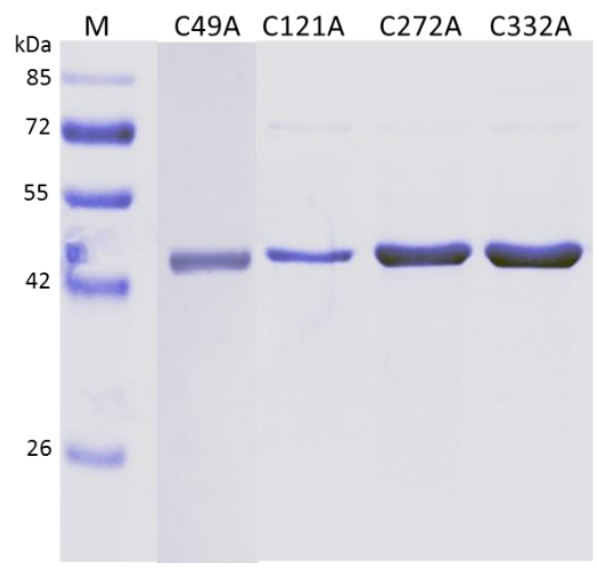

38. ábra: Tisztított mutáns SqrF fehérjék SDS-PAGE képe 


\subsubsection{2. $\quad \underline{A z}$ SqrF fehérje variánsok spektroszkópiai és katalítikus vizsgálata}

A vad típusú SqrF-hez hasonlóan abszorbancia spektrum felvételével vizsgáltam a mutáns fehérjék kofaktor tartalmát. Látható, hogy a C121A mutáns kivételével azonosíthatóak 360 és 450 nm-en fényelnyelési maximumok a spektrumokban, melyek a fehérjék FAD tartalmát igazolják. A C121A esetében a 121.cisztein alaninra történő cseréje következtében a fehérje kofaktort nem tartalmaz (39/A. ábra).

A

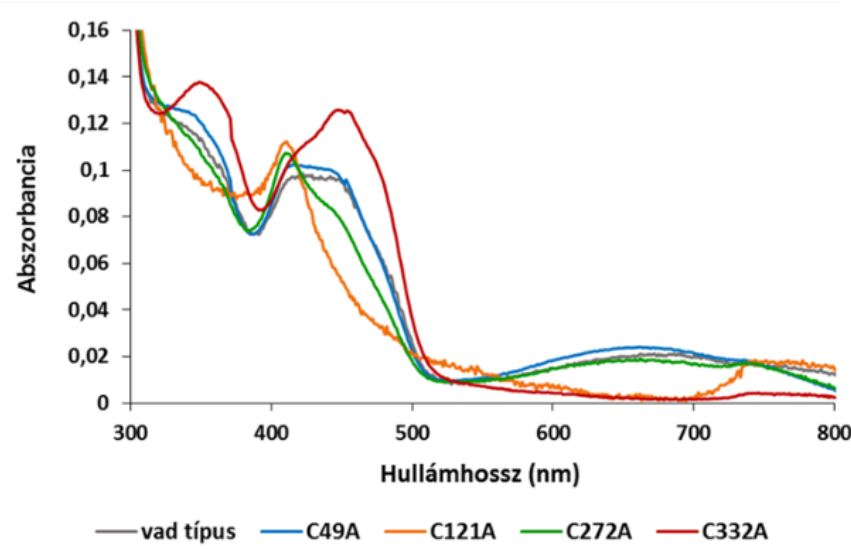

B

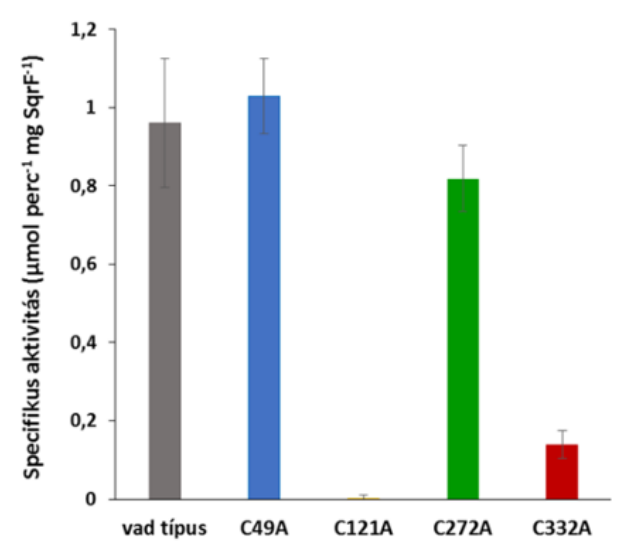

39. ábra: A vad típusú SqrF enzim és cisztein pontmutáns variánsainak abszorbancia spektruma (A), valamint szulfid függő kinon redukáló aktivitása (B)

A vad típusú és a mutáns enzimek szulfid függő DQ redukáló aktivitását összehasonlítva, a C49A és C272A variánsok aktivitása hasonló, mint a vad típus esetében. A C121A mutáns fehérje nem volt képes szulfid függő DQ redukciót katalizálni, ami összefüggésben áll a spektrális vizsgálat eredményével, hiszen ez az enzim változat FAD kofaktort nem tartalmaz, mely eszenciális a fehérje müködése szempontjából. A C121 aminosav esetében lehet, hogy a kofaktor kötés mellett más funkciója is lehet ennek az aminosavnak, azonban az aktivitás hiánya miatt további szerepét ilyen kísérleti elrendezésben nem lehet vizsgálni. A 332. pozícióban lévő cisztein cseréje alaninra drasztikus aktivitás csökkenésben mutatkozik meg (39/B. ábra), mely alapján ennek a ciszteinnek fontos, de nem nélkülözhetetlen szerepe van, a fehérje müködésében. 


\subsubsection{3. $\quad \underline{\text { SqrF enzim variánsok kinetikai paraméterei }}$}

Következőekben megvizsgáltam a katalizáló SqrF variáns enzimek aktivitásának szubsztrát (szulfid) illetve koszubsztrát (durokinon) koncentrációtól való függését. Ezekből az adatokból a vad típusú enzimnél alkalmazott számítási módszerrel meghatároztam a kinetikai paramétereket, melyeket a vad típusú SqrF enzim értékeivel hasonlítottam össze (3. táblázat).

\begin{tabular}{lllllll}
\hline Fehérje & \multicolumn{1}{c}{$\begin{array}{c}\mathbf{V}_{\text {max }} \\
\left(\mu \mathrm{mol} \mathrm{perc} \mathbf{~}^{-1} \mathbf{m g}^{-1}\right)\end{array}$} & $\begin{array}{c}\mathbf{k}_{\text {cat }} \\
\left(\mathbf{s}^{-1}\right)\end{array}$ & $\begin{array}{c}\mathrm{Km}(\mathrm{Na} 2 \mathrm{~S}) \\
(\mu \mathrm{M})\end{array}$ & $\begin{array}{c}\mathrm{Km}(\mathrm{DQ}) \\
(\mu \mathrm{M})\end{array}$ & $\begin{array}{c}\mathbf{k}_{\text {cat }} / \mathrm{Km} \\
\left(\mathrm{Na}_{2} \mathrm{~S}\right) \\
\left(\mu \mathrm{M}^{-1} \mathbf{s}^{-1}\right)\end{array}$ & $\begin{array}{c}\mathbf{k}_{\text {cat }} / \mathrm{Km}(\mathrm{DQ}) \\
\left(\mu \mathrm{M}^{-1} \mathbf{s}^{-1}\right)\end{array}$ \\
\hline SqrF vt & $2,29 \pm 0,19$ & $1,64 \pm 0,14$ & $209 \pm 30$ & $27,39 \pm 2,47$ & 0,008 & 0,060 \\
C49A & $3,4 \pm 0,1$ & $2,46 \pm 0,07$ & $339,4 \pm 7,3$ & $27,5 \pm 1,8$ & 0,007 & 0,089 \\
C121A & 0 & 0 & n. m. & n. m. & n. m. & n. m. \\
C272A & $1,4 \pm 0,1$ & $1,01 \pm 0,09$ & $183,1 \pm 27$ & $41,88 \pm 2,96$ & 0,006 & 0,024 \\
C332A & $0,26 \pm 0,04$ & $0,19 \pm 0,03$ & $155 \pm 19$ & $35,8 \pm 14,3$ & 0,001 & 0,005 \\
\hline
\end{tabular}

3. táblázat: Cisztein mutáns SqrF variánsok enzimkinetikai paraméterei

\subsubsection{4. $\quad$ A vad típusú SqrF enzim gátlási vizsgálata}

Az SQR típusú enzimek által katalizált reakciók gátlása megoldható, ha olyan alkiláló szereket (jódacetamid (IAA), jódecetsav) alkalmazunk, melyek képesek a katalízisben fontos szerepet játszó ciszteinek szabad szulfhidril csoportjaihoz irreverzibilisen kötődni. Az alkiláló szulfhidril reagenseknek a ciszteinekkel való reakciójának eredményeként az enzimben nem alakulnak ki diszulfid hidak illetve a ciszteinek gátolt szulfhidril csoportjai nem vesznek részt a kémiai folyamatokban.

A vad típusú SqrF enzim gátolhatóságát jódacetamiddal és jódecetsavval vizsgáltam. Mindkét esetben a gátlószert különböző koncentrációkban közvetlenül az enzimet és durokinont tartalmazó aktivitás mérési reakcióelegyhez adtam, majd anaerobizálást követően szulfid hozzáadásával indítottam a reakciót és kezdtem az enzim minták gátlószer jelenlétében mutatott szulfid függő kinon redukáló aktivitásának mérését.

A jódacetamid alkalmazása mellett teljes gátlást már $300 \mu \mathrm{M}$-os koncentrációnál tapasztaltam, addig a jódecetsav esetén ez $500 \mu \mathrm{M}$-nál valósult meg (40. ábra), mely 
alátámasztja, hogy a jódecetsavhoz képest a jódacetamid hatékonyabban képes reagálni a tiol-csoportokkal.

A

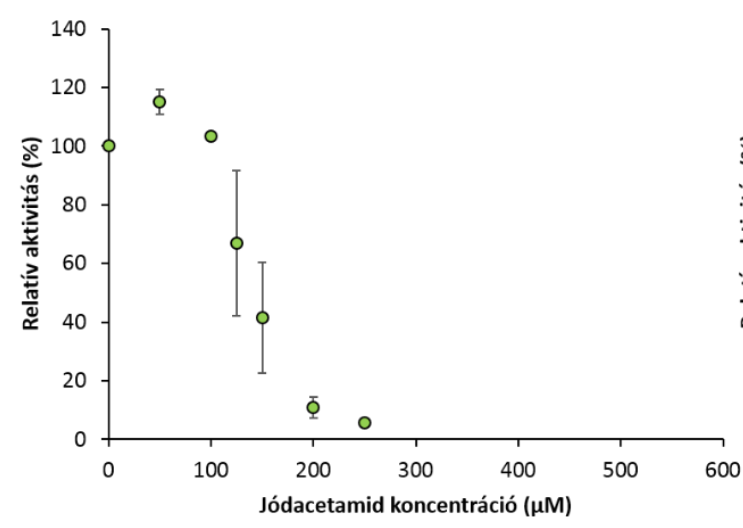

B

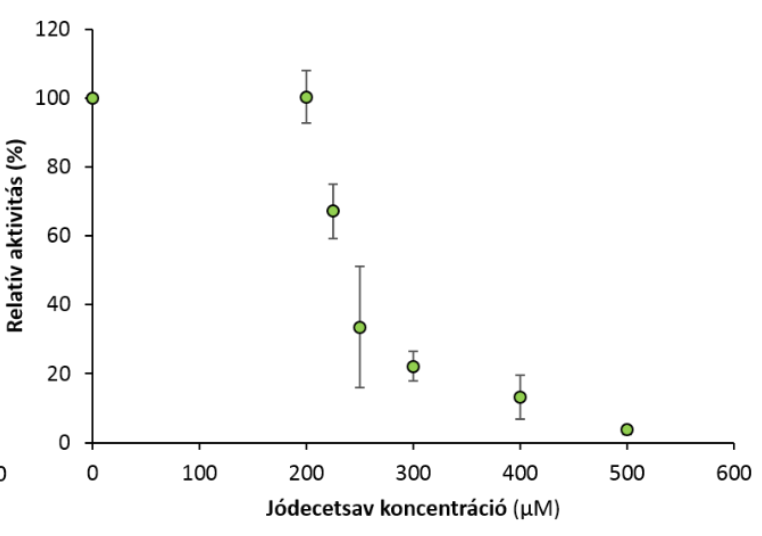

40. ábra: Vad típusú SqrF enzim relatív aktivitása jódacetamid (A) és jódecetsav (B) jelenlétében

Megvizsgáltam továbbá azt is, hogy az enzim képes-e a fehérjék gátlószerrel való kezelését követően katalizálni a szulfid függő kinon redukciót. A tisztított fehérjéhez csak gátlószert adtam és inkubáltam az elegyet 1 órán át $25^{\circ} \mathrm{C}$-on. A kontroll elegyben $0 \mathrm{mM}$, a mintákba $1 \mathrm{mM}$ jódacetamiddal kezeltem az enzimet. Ezt követően megmértem a kontrol és kezelt enzim minták szulfid függő kinon redukáló aktivitását. Ebben az esetben a kontrolhoz képest gátlás nem következett be (41. ábra), ellentétben, amikor a gátlószert közvetlenül az enzim aktivitás mérőreakcióelegyekhez adtam.

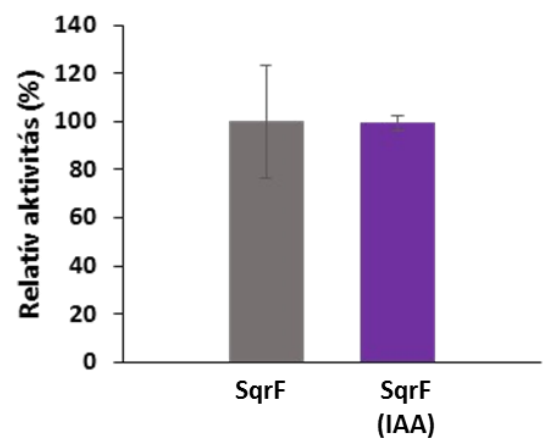

41. ábra: Jódacetamiddal inkubált és kontroll vad típusú SqrF relatív szulfid függő kinon redukáló aktivitása 


\subsubsection{5. $\quad$ Cisztein mutáns SqrF variáns enzimek gátlási vizsgálata}

Az SqrF fehérjében levő ciszteinek szerepének részletesebb megismerése céljából, megvizsgáltam a vad típusú enzimhez hasonlóan az SqrF cisztein variánsok IAA általi gátolhatóságát.

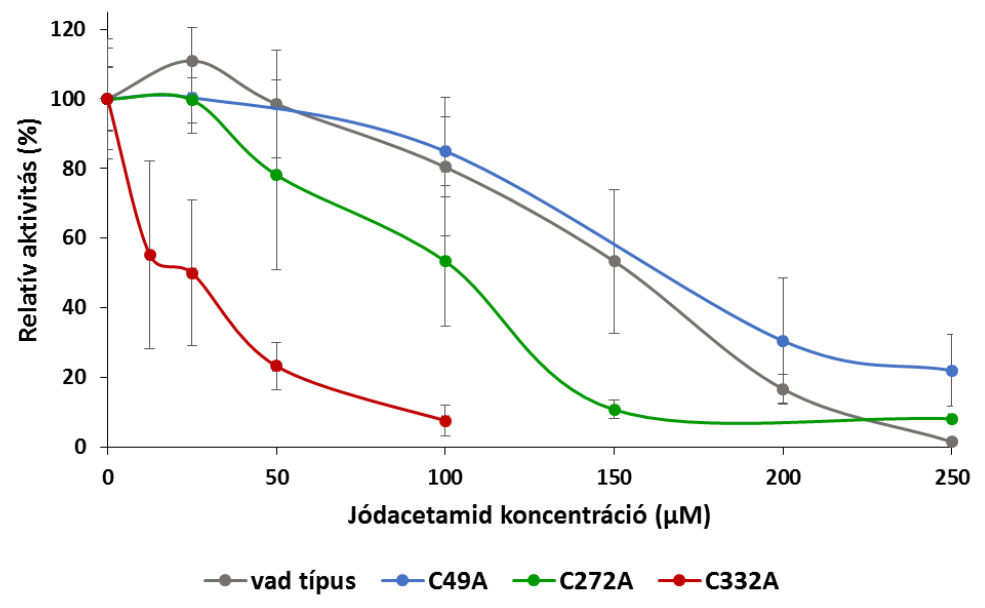

42. ábra: A vad típusú és variáns SqrF enzimek relatív aktivitása különböző koncentrációjú jódacetamid jelenlétében

A vad típushoz hasonló gátlás kinetikát mutat a C49A mutáns, ahol az 50\%-os aktivitás kb. $150 \mu \mathrm{M}$ IAA mellett, a teljes gátlást pedig $250 \mu \mathrm{M}$ hozzáadásánál érte el. A C272A esetében kismértékü változás figyelhető meg, az aktivitása már $100 \mu \mathrm{M}$ alkiláló szer alkalmazása mellett felére csökken, teljes aktivitás vesztés kb. $150 \mu \mathrm{M}$ gátlószer használatával valósul meg. Számottevő különbség fedezhető fel a C332A variáns esetében, ahol már $25 \mu \mathrm{M}$ IAA mellett 50\%-os aktivitás vesztés figyelhető meg, a teljes gátlás pedig $100 \mu \mathrm{M}$-os koncentráció alkalmazásánál tapasztalható (42. ábra).

\subsubsection{6. $\quad$ A vad típusú SqrF enzim FAD kötésének vizsgálata jódacetamid jelenlétében}

A jódacetamid csak az enzim szubsztrátjainak jelenlétében volt képes az SqrF fehérje aktivitását gátolni, tehát csak a katalitikusan aktív enzim esetében fejti ki gátló hatását. Egy komplex kísérlet keretén belül meghatároztam, hogy az SqrF fehérje FAD kofaktor-kötő képessége hogyan változik jódacetamiddal való kezelés miatt kialakult enzimgátlás hatására. A kísérlettel arra a kérdésre is választ kerestem, hogy a feltételezhetően a FAD kovalens 
kötésében szerepet játszó ciszteinnek (C121) van-e szerepe az enzim müködési mechanizmusában, esetleg ennek a konzervált ciszteinnek a jódacetamiddal végbemenő reakciója lehet-e felelős az enzim gátlásáért.

Nagyobb koncentrációjú fehérjét $(25 \mu \mathrm{M})$ DQ és $\mathrm{Na}_{2} \mathrm{~S}$ jelenlétében inkubáltam jódacetamid jelenlétében, illetve kontrol minta esetében jódacetamid nélkül. Az inkubációt követően vizsgáltam a mintákban lévő kezelt enzimek szulfid függő DQ redukáló aktivitását, ahol az alkalmazott IAA részleges gátlást okozott (43/A. ábra). A jódacetamidot tartalmazó minta abszorbancia spektruma láthatóan eltért a kontroll minta spektrumához képest, mely a fehérjében lévő FAD redox állapotának változásával magyarázható (43/B. ábra). A gátlószerrel kezelt és nem kezelt kontroll fehérjét is denaturáltam TCA-val, majd a centrifugálás utáni felülúszó spektrumát is meghatároztam, melyeken látszik, hogy a kontroll minta spektrumában nem, azonban a részlegesen gáltolt majd denaturált enzim felülúszójának esetében kimutatható a FAD jelenléte, így az SqrF fehérjéhez való kötődésének megszűnése, ami lehetővé teszi a fehérjéből való felszabadulását (43/B. ábra).
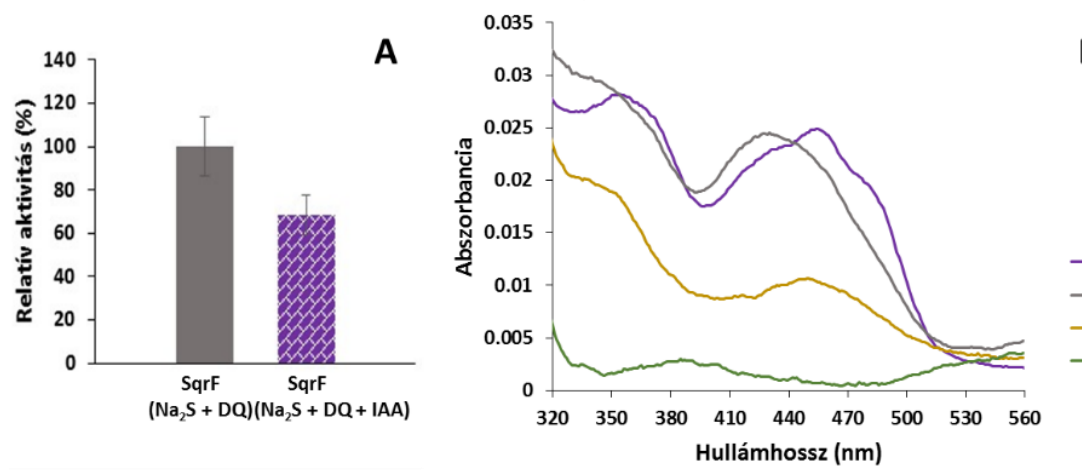

B

- SqrF $\left(\mathrm{Na}_{2} \mathrm{~S}+\mathrm{DQ}\right)$

$-\operatorname{SqrF}\left(\mathrm{Na}_{2} \mathrm{~S}+\mathrm{DQ}+\mathrm{IAA}\right)$

- TCA-val denaturált SqrF + IAA felülúszó

- TCA-val denaturált SqrF - IAA felülúszó

43. ábra: Jódacetamiddal kezelt és nem kezelt minták relatív aktivitása (A), illetve abszorbancia spektruma (B) 


\section{Diszkusszió}

\subsection{Szulfid kinon oxidoreduktázok Thiocapsa roseopersicina-ban}

A Thiocapsa roseopersicina genomban azonosítottam két szulfid kinon oxidoreduktáz gént, melyek levezethető termékei filogenetikai és többszörös fehérjeszekvencia analízis alapján két külön SQR típusba sorolhatóak. Az SQR fehérjék csoportosításán alapuló legújabban elfogadott nevezéktan alapján neveztem el a géneket $s q r D$ és $s q r F$-nek, az általuk kódolt fehérjéket pedig SqrD-nek, mely IV. típusú, illetve SqrFnek, amely pedig a VI. csoport tagja. A IV. alcsaládból még egy enzimet sem jellemeztek, a VI. csoport egy csak részlegesen jellemzett képviselővel (Chlorobaculum tepidum SqrF (CT1087)) [60] rendelkezik, melyről leírják, hogy FAD-tartalmú enzim, továbbá meghatározták kinetikai paramétereit.

Gyakori a baktériumok körében, hogy több, különböző csoportba sorolható SQR típusú fehérjével rendelkeznek. A bíbor kénbaktériumok legrészletesebben vizsgált képviselöjének az A. vinosumnak (a T. roseopersicina nagyon közeli rokona) genomjában, szintén azonosítottak 2 szulfid kinon oxidoreduktáz gént, melyekről átíródó fehérjék a IV. és a VI. típusba sorolhatóak [62,91]. Ezen felül az A. aeolicus egy SqrA [50] és egy SqrF [65], C. tepidum pedig SqrC, SqrD, SqrE és SqrF fehérjéket is tartalmaznak [44,60].

A VI. típusú Sqr fehérje számos proteobaktériumban megtalálható, például bíbor kénbaktériumokban (A. vinosum) [62]; zöld kénbaktériumokban (C. tepidum) [60] és nem kén fotoszintetikus baktériumokban ( $R$. capsulatus) [92], emellett nem fotoszintetikus (Acidithiobacillus ferrooxidans) [93] (Axidovorax sp.) [94] baktériumokban is.

Az SqrF fehérjék széles körben elterjedtek az élővilágban, az előbbiekben felsorolt csoportokon kívül megtalálhatóak eukariótákban élö endoszimbionta mikroorgamizmusokban is: SqrF enzimet találtak Calyptogena okutanii mélytengeri kagyló [95], Riftia pachyptila és Tevnia jerichonana csőférgek [96] illetve egy monjui pikkelyes csiga izolátum [97] endoszimbiontájában is. Ezen állatok élőhelye szulfidban gazdag, endoszimbiontájuk szerepe a szulfid oxidáción keresztüli energianyerés, mely energiából szerves anyagokat állítanak elő gazdaszervezetük számára [95]. 


\begin{tabular}{ccc}
\hline Mikroorganizmus & \multicolumn{2}{c}{$\begin{array}{c}\text { T. roseopersicina SqrF } \\
\text { szekvencia }\end{array}$} \\
\hline Calyptogena okutanii kopoltyú szimbionta & $\underline{\text { azonosság (\%) }}$ & $\underline{\text { hasonlóság (\%) }}$ \\
Riftia pachyptila endoszimbionta & 63 & 78 \\
Tevnia jerichonana endoszimbionta & 69 & 81 \\
Solemya pervernicosa kopoltyú szimbionta & 69 & 81 \\
Ridgeia piscesae endoszimbionta & 71 & 80 \\
Bathymodiolus thermophilus kopoltyú szimbionta & 69 & 81 \\
\hline
\end{tabular}

4. táblázat: Endoszimbionta mikroorganizmusok VI. típusú szulfid kinon oxidoreduktáz fehérjéinek a $T$. roseopersicina SqrF fehérjével mutatott azonossága és hasonlósága

A T. roseopersicina $\mathrm{SqrF}$ fehérje nagyfokú azonosságot/hasonlóságot mutat az endoszimbiontákban lévő VI. típusú Sqr fehérjékkel (4. táblázat). Továbbá az SQR fehérjék filogenetikai analízise is felfedte, hogy a bíbor kénbaktériumokban található SqrF fehérjék és az endoszimbionták SQR enzimei a VI. típusú szulfid kinon oxidoreduktázokon belül ugyanazon a fejlődési ágon alakultak ki. A T. roseopersicina SqrF enzim részletes jellemzésével, müködési mechanizmusának feltárásával különösen jó modellje lehetne ezen különleges élőlények SqrF fehérjéknek is, melyek laboratóriumi körülmények között nehezen szaporítható organizmusokban találhatóak, emiatt vizsgálatuk nehezen elvégezhető.

T. roseopersicina-ban lévő szulfid kinon oxidoreduktáz fehérjéket kódoló gének promótere szulfiddal indukálható, az sqrD gén $1 \mathrm{mM}$, míg az $s q r F$ pedig 2,5 $\mathrm{mM}$ tápoldatbeli $\mathrm{Na}_{2} \mathrm{~S}$ koncentrációnál érte el a legmagasabb génkifejeződést. Az előbb említett szulfid koncentráció mellett végzett, mindkét SQR enzimet tartalmazó kontroll (GB1121) törzshöz képest az SqrD (15/A. ábra) és SqrF mutáns törzsek (15/B. ábra) in vivo szulfid hasznosítási vizsgálatából kiderült, hogy a fehérjék hiánya a mutáns sejtek lassabb nátrium-szulfid felhasználását eredményezi. A vizsgált SqrD, illetve SqrF fehérjéket tartalmazó és nem tartalmazó $T$. roseopersicina törzsek membrán frakcióján végzett in vitro szulfid függő kinon redukáló aktivitás vizsgálatok szerint, az $\mathrm{SqrD}$ és SqrF enzim is aktív a sejtek membrán frakciójában, ez alapján szerepet játszhat a sejtmembrán szulfid függő kinon redukáló aktivitásában. Mindezen eredmények: a szulfid függő promóter, in vivo 
kénanyagcserében való szerep bizonyítása, továbbá a membrán frakcióban igazolt in vitro aktivitás alátámasztja, hogy az azonosított génekről képződő fehérjék szulfid kinon oxidoreduktázok, melyek részt vesznek a $T$. roseopersicina összetett kénanyagcseréjében. A kísérletek során alkalmazott szulfid koncentráció tartományban az sqrD alacsonyabb, míg az sqrF gén magasabb szulfid koncentrációnál érte el kifejeződése maximumát. Valószínű, hogy a sejtek számára evolúciós előnyt jelent a két eltérő típusú és feltehetően eltérö katalitikus tulajdonságokkal rendelkező szulfid oxidáló enzim jelenléte.

\subsection{Rekombinánis szulfid kinon oxidoreduktázok termeltetése és tiszítása}

A fehérjék biokémiai összehasonlításához nélkülönözhetetlen a tisztított SqrD és SqrF fehérje. Ennek érdekében előállítottam a fehérjéket C- vagy N-terminálison StrepII affinitás peptiddel ellátott formában termelő expressziós vektorokat, melyek T7 és $\mathrm{crtD}$ promóterük miatt mind E. coli, mind T. roseopersicina sejtekben is alkalmasak a fehérjék expresszáltatására. Az expressziós vektorok sejtekbe jutattásával létrehoztam a rekombináns SqrD vagy SqrF fehérjéket termelö E. coli és T. roseopersicina törzseket.

Az eddig jellemzett SQR fehérjék közül az A. ferrooxidans SqrA [64], C. maquilingensis SqrC [41] és $R$. capsulatus SqrA [36] fehérjéket tudták termeltetni E. coliban és tisztítani ezen sejtek membrán frakciójából. Az A. aeolicus SqrA [65] és az A. ambivalens SqrE fehérjék esetén[66] csak homológ gazdából sikerült tisztítani az SQR fehérjéket.

A T. roseopersicina $\mathrm{SqrD}$ és SqrF esetében az E.coli törzsek IPTG hozzáadását követően nagy mennyiségben termelték a fehérjéket, azonban a képzödött fehérjék oldhatatlan csapadékot alkottak, ezért tisztításuk illetve aktív formába hozásuk nem volt lehetséges. Továbbiakban az SqrD és SqrF fehérjék termeltetését homológ gazdában, T. roseopersicina törzsekben valósítottam meg.

A membránkötött SQR fehérjék membránból való felszabadítását és oldatban való stabilizálását általában a nem-ionos detergens DDM használatával érték el [41,65]. A T. roseopersicina SqrD fehérje egyik változatát sem sikerült a membránból felszabadítani, sem DDM, sem számos más nem-ionos vagy ikerionos detergensek egyedüli vagy kombinált használatával. Az SqrF esetében az alkalmazott detergensek változó mennyiségben képesek voltak felszabadítani a rekombináns fehérjét a membránból, amelyet affinitás kromatográfiával sikeresen tisztítottam, azonban a tisztított fehérje mennyiség egyik esetben 
sem volt elegendő a további vizsgálatokra. További problémát jelentett az elúciós frakciók fotoszintetikus pigmentekkel való szennyeződése.

Ezért következö lépésben a $R$. capsulatus esetén is alkalmazott 2M NaBr [45] kaotróp sóval kezeltem a membrán frakciókat. Az SqrD fehérje szolublizálása ugyan nem sikerült ezzel a módszerrel, azonban az SqrF fehérjét jelentősen nagyobb mennyiségben sikerült felszabadítani a membrán frakcióból, mint detergensek használatával. A NaBr-al való membránkezelés utáni UC-felülúszónak hasonlóan a detergenssel kezelt membrán frakció UC-felülúszójának erős piros színe volt. A felszabadított fehérjéket tartalmazó felülúszó affinitás kromatográfia utáni elúciós frakció abszorbancia spektruma alapján az SqrF fehérje mellett fotoszintetikus pigmentek jelenlétét jelezte. Feltételezésem szerint, az ultracentrifugálás során a magas koncentrációjú $\mathrm{NaBr}$ oldatban kialakul egy $\mathrm{NaBr}$ grádiens, amelynek a kiindulásinál magasabb sókoncentrációjúvá váló frakciójában nem képesek leülepedni azon SqrF fehérjét tartalmazó kisebb membrán darabok, melyek a $\mathrm{NaBr}$ kezelés hatására jöhetnek létre a sejtmembránból. Ezért hígítással csökkentettem a membrán kezelésre alkalmazott $\mathrm{NaBr}$ koncentrációját 1,5 M-ra, annak reményében, hogy az SqrF fehérje felszabadításának hatékonysága ne változzon, de az ultracentrifuga során olyan $\mathrm{NaBr}$ grádiens épüljön fel, melyben képesek lesznek leülepedni a membrán frakció szolubilizálást követő UC-felülúszóban lévő kisebb membrán darabok. Továbbá emeltem a kezelés utáni UC fordulatszámán megadva a kellő erőt, hogy a kisebb membrán darabok képesek legyenek leülni a csapadék frakcióba. A membrán kezelése során alkalmazott 1,5 M NaBr képes volt az SqrF fehérjét szolubilizálni a membránból. Azonban ugyanannyi térfogatú kultúra membrán frakciójának kezelése után a pigment-mentes UC-felülúszó mennyiség változó volt, ezáltal a tisztítható fehérje mennyisége is. Ennek oka lehet a sejtek állapotában, illetve a belőlük izolált membránok szerkezetében lévő lehetséges különbségek, valamint az ugyanolyan koncentrációban alkalmazott kaotróp só membrán frakcióhoz való hozzáferhetősége változó lehet. Megoldásként a sejtek membrán frakciójának szerkezetbeli változtatását terveztem. A membrán szerkezet lazítása érdekében a sejtfeltárás során a periplazma frakció eltávolítása mellett $10 \mathrm{mM}$ EDTA kezelést iktattam be a membrán sejtfrakció izolálása és $\mathrm{NaBr}$-al történő kezelése előtt, mely során a stabilizáló kétértékü kationokat lekötöttem, ezáltal a $\mathrm{NaBr}$ könnyebben tudta a fehérjét felszabadítani a sejtek külső membrán rétegétől elválasztott sejtmembránból. Mindkét fejlesztési lépés számottevően hozzájárult a nagyobb fehérje kihozatal eléréséhez. 
A membrán frakció $\mathrm{NaBr}$-al való kezelése utáni UC-felülúszó teljes mennyiségéből való fehérje tisztítás érdekében meg kellett oldanom a felülúszó pigment mentesítését. A szolubilizált fehérjéket tartalmazó UC-felülúszó $\mathrm{NaBr}$ tartalmát 1,4 M-ra csökkentettem. A csökkentett $\mathrm{NaBr}$ koncentráció miatt egy következő ultracentrifugálás során már képesek voltak leülepedni a fehérjékhez kötött kisebb membrán darabok is és a szolubilizált fehérjék is oldatban maradtak. Így a felülúszó teljes térfogatából lehetett fehérjét tisztítani, mely a további biokémiai vizsgálatokra alkalmas.

Az SqrD és SqrF fehérjét egyaránt sikerült expresszálni E. coli és T. roseopersicina törzsekben is. Az SqrD fehérjét sem detergensekkel, sem kaotróp só használatával sem sikerült felszabadítanom a membrán frakcióból, míg az SqrF-et detergens jelenlétében kis mennyiségben, $\mathrm{NaBr}$-al pedig nagyobb mennyiségben sikerült mind szolubilizálni, mind tisztítani. A tisztított rekombináns T. roseopersicina SqrF fehérje kihozatala $150 \pm 59 \mu \mathrm{g} / \mathrm{L}$ kultúra, ami kevesebb, mint az irodalomban olvasható értékek: A. aeolicus SqrA ( $3 \mathrm{mg} / \mathrm{L})$ [65], C. maquilensis $\mathrm{SqrC}$ (2 mg/L) [41], C. tepidum $\mathrm{SqrF}(0,7 \mathrm{mg} / \mathrm{L})$ [60].

A fehérjék membránból való kinyerhetőségében mutatkozó különbség feltételezésem szerint a fehérjék C-terminálisához köthetö. Számos funkciót kötnek a szulfid kinon oxidoreduktázok C-terminálisához, melyek szerepe az SQR típusú fehérjék csoportjai között igen változatos. Ezt a régiót teszik felelőssé a fehérje lokalizációért, az oligomerizációért, kinon analógokra adott érzékenységért és nem utolsó sorban a membránhoz való kötődésért [59,67]. Kísérletesen igazolták a C. maquilingensis SqrC enzimnél, hogyha levágták a fehérje C-terminálisát a fehérje nem volt képes a membránhoz kötődni, a citoplazmában maradt és aktivitását is elvesztette [41]. A IV. típusú SqrD egy hosszabb C-terminális régióval rendelkezik, mint a VI. típusú $\mathrm{SqrF}$, így valószínüleg mélyebben képes a membránba beágyazódni, vagy erősebb kötéssel, mint az SqrF, ezért nem sikerült sem detergensekkel, sem $\mathrm{NaBr}-a$ l felszabadítani a membránból. Ezzel ellentétben az SQR típusok között a legrövidebb C-terminális régióval rendelkező VI. csoportba tartozó SqrF már kaotróp ágenssel is szolubilizálható volt.

\subsection{A tisztított SqrF fehérje biokémiai sajátságai}

A tisztított rekombináns SqrF fehérje minta SDS-PAGE során egy sávot alkot 44 kDa magasságban, azonban natív grádiens gélen való Western analízis során 3 különálló sávot lehet detektálni, melyeket feltételezhetően a fehérje monomer, dimer és trimer formái 
alkotnak. Ez korrelál azon irodalmi adatokkal, miszerint a kikristályosított tisztított A aeolicus SqrA kristályrácsaiban trimer formában azonosították a fehérjét [67], az A. ferroxidans I. típusú SQR fehérje esetében pedig dimer formában [68]. Marcia és munkatársai kimutatták, hogy a tisztított $A$. aeolicus SqrA fehérje glutárdialdehid kezelés után SDS tartalmú denaturáló gélen 3 sávot adott, amelyek mérete megegyezett a monomer, dimer, trimer formák in silico számításokkal meghatározott méretével [65].

A tisztított fehérje abszorbancia és a fluoreszcens emissziós spektruma is igazolta a FAD kofaktor tartalmat, mely oxidált állapotú a fehérjében az adott tisztítási protokol mellett. Az abszorbancia spektruma alapján a kitisztított SqrF mintákban a FAD prosztetikus csoportot tartalmazó fehérjék aránya közel 75\%, ami szinte megegyezik a tisztított A. ferrooxidans SqrA 72\%-os [98], illetve C. tepidum SqrF fehérje 75\%-os FAD tartalmával [60] és jobb a C. maquilingensis SqrC enzimnél leírt 50-60\% FAD tartalomnál [41]. Az SqrF mind nátrium-dithionit, mind szulfid hatására elredukálódott, majd durokinon hozzáadásával oxidálódott az eredeti redox állapotra, tehát redox-aktív kofakort tartalmaz a fehérje.

Az SQR fehérjékben lévő FAD kovalens kötéséért a 124. cisztein illetve homológjai felelősek [59,66], kivételt képez az A. ferrooxidans SqrA fehérje, melynél megtalálható a konzervált cisztein, a fehérje mégsem köti kovalensen a kofaktort [68]. A II. és III. típusú SQR enzimekből hiányzik ezen cisztein, $C$. maquilingensis $\mathrm{SqrC}$ enziménél kísérletesen is bizonyították, hogy nincs kovalens kapcsolat a FAD és a fehérje között [41]. Hasonló kísérletes módszerrel igazoltam, hogy a $T$. roseopersicina SqrF fehérjében a FAD prosztetikus csoport kovalens módon rögzített, amelyet a denaturáló gélelektroforézis gélben futattott SqrF fehérjék detektált fluoreszcenciája is megerősített. A FAD csoport kötése a fehérjéhez az irodalmi adatok alapján és vizsgálataink szerint a 121. pozícióban található konzervált cisztein részvételével valósul meg.

Meghatároztam, hogy az SqrF enzim csak kinon szubsztrátot képes elfogadni elektronakceptorként. Megvizsgáltam milyen kinonoknak képes átadni a szulfidról származó elektronokat. Több menakinon és ubikinon típusú kinont vizsgáltam, mivel a fakultatív anaerob proteobaktériumok sejtmembránjában mindkét típus előfordul [41] [99].

Az ubikinonok általánosan $150 \mathrm{mV}$-al magasabb redox potenciállal rendelkeznek, mint a menakinonok. A kinonok közötti redox potenciál különbség lehet az oka, hogy az ubikinonok a légzési lánc folyamatában, míg a menakinonok a fotoszintetikus elektrontranszferlánc folyamatában játszanak szerepet [33,99]. Ezt támasztja alá a 
kénbaktérium Halorhodospira halophila esetén bizonyított tény, hogy az UQ-8-at a légzési láncban, míg a MK-8-at fotoszintetikus elektrontranszferláncban használja a sejt [100].

\begin{tabular}{cccccccc}
\hline & & \multicolumn{2}{c}{ I. típusú SQR } & II. típusú SQR & III. típusú SQR & V. típusú SQR & VI. típusú SQR \\
& & A. aeolicus & O. limnetica & S. pombe & C. maquilingensis A. ambivalens & T. roseopersicina \\
& Decilubikinon & 28 & - & - & 100 & 100 & 100 \\
& Durokinon & - & 21 & - & 23 & - & 32 \\
Ubikinon típusú & Ubikinon-1 & 100 & 100 & - & - & - & - \\
kinon & Ubikinon-2 & - & - & 100 & - & - & - \\
vegyületek & Ubikinon-4 & 26 & - & - & - & - & - \\
& Ubikinon-9 & 53 & - & - & - & - & - \\
Menakinon & Ubikinon-10 & - & - & - & - & - & 4 \\
Menadion & - & - & - & 25 & - & 0,36 \\
vegusú kinon & Menakinon-4 & - & - & - & - & - & 1,42 \\
\hline
\end{tabular}

5. táblázat: SQR típusú fehérjék relatív aktivitása különböző kinon elektronakceptorok alkalmazásával

A T. roseopersicina $\mathrm{SqrF}$ enzim a kinon preferenciájának vizsgálat alapján az ubikinon típusú kinonokat képes elfogadni nagy hatékonysággal (35. ábra). A T. roseopersicina membrán kinon raktára mind ubikinonokat mind menakinonokat tartalmaz (Rákhely, személyes közlés). Az ubikinon típusú kinonokkal mutatott magasabb SqrF aktivitás hasonló más típusba tartozó SQR enzimek esetében mért eredményekkel: A. aeolicus SqrA [65], O. limnetica SqrA [43], S. pombe SqrB [52], C. maquilingensis SqrC [41], A. ambivalens SqrE [66] enzimek is nagyobb aktivitással képesek redukálni az ubikinonokat (5. táblázat).

Az SqrF szulfid függő durokinon redukáló aktivitásának hőmérsékletfüggése szokatlan képet mutat: $55^{\circ} \mathrm{C}$ inkubációs hőmérsékletig folyamatos az enzim aktivitásának a növekedése, azonban ennél az értéknél kis mérékben magasabb hőmérsékleten már hirtelen drasztikus aktivitás csökkenés volt megfigyelhető, $60{ }^{\circ} \mathrm{C}$-on teljesen inaktív az enzim. A hőmérsékletfüggés görbe két szakaszára eltérő exponenciális összefüggés mutatható ki a hőmérséklet és a specifikus aktivitás közt. A tisztított SqrF decilubikinon redukáló aktivitásának hőmérsékletfüggése eltér az előzőtől. Az enzim a maximális aktivitását már 45 ${ }^{\circ} \mathrm{C}$-on elérte, magasabb hőmérsékleteken csökkenést mutatott, azonban ez a csökkenés nem olyan drasztikus, mint durokinon esetén. Feltételezhetően a hőmérséklet növelésével tapasztalt csökkent enzim aktivitást nem csak a fehérje szerkezeti változása okozza, hanem a fehérje és a szubsztrát kapcsolata is változik. Ezáltal az enzim különböző sebességgel képes katalizálni a kinon redukciót eltérő szerkezetü szubsztrátok esetén. A katalizáció sebessége tehát függ a szubsztrát szerkezetétől illetve az enzimhez való 
kötődésétől is. A fiziológiás hőmérsékleti tartományban mért dUQ redukáló aktivitásra szintén exponenciális összefüggés mutatható ki. A hőmérsékleti függésekből számolt aktivációs energiák eltérőek az alkalmazott kinonok esetében. A fiziológiás hőmérséklet tartományban a szulfid függő decilubikinon redukció aktivációs energiája $35,8 \mathrm{~kJ} \mathrm{~K}^{-1} \mathrm{~mol}^{-1}$, a míg durokinon redukciója körülbelül kétszer magasabb: 73,6 $\mathrm{kJ} \mathrm{K}^{-1} \mathrm{~mol}^{-1}$.

Irodalmi adatokkal összevetve az SqrF enzim fiziológiás hőmérséklet tartományban mért aktivációs energiái eltérőek más típusba tartozó $\mathrm{SQR}$ enzimek esetében meghatározott értékektől. Az SqrF enzim decilubikinon redukáló aktivitásának aktivációs energiájára meghatározott $35,8 \mathrm{~kJ} \mathrm{~K}^{-1}$ mol$^{-1}$ magasabb, mint az I. típusú A. aeolicus $\operatorname{SqrA}\left(14,0 \mathrm{~kJ} \mathrm{~K}^{-1}\right.$ $\left.\mathrm{mol}^{-1}\right)$ [65] és az A. ferrooxidans SqrA $\left(29,6 \mathrm{~kJ} \mathrm{~K}^{-1} \mathrm{~mol}^{-1}\right)$ [98] enzimeknél mért érték, a durokinon jelenléte mellett kapott SqrF aktivációs energia érték pedig számottevően magasabb. Tehát a $T$. roseopersicina $\mathrm{SqrF}$ katalízise közben több energia szükséges a reakciósebességet meghatározó köztes termék kialakulásához, a szulfid függő kinon redukció több lépéses redox reakciósorozatának végbemeneteléhez. Feltételezhetően az elektronakceptor funkciójú kinon szerkezete erősen befolyásolja az SqrF katalizálta reakció aktivációs energiáját.

Az SqrF szulfid függő kinon redukáló aktivitás szubsztrátfüggései alapján meghatározott kinetikai paraméterek alapján elmondható, hogy az SqrF enzimnek a mérésekben alkalmazott kétféle kinonhoz való affinitása szinte azonos, azonban a decilubikinont több mint ötször gyorsabban képes redukálni, melyet a $\mathrm{k}_{\text {cat }}$ értékek is mutatnak (3. táblázat). E hatás hátterében akár a kinonok redoxpotenciál különbsége és / vagy a különböző kinonok redukciós reakciójára számolt eltérő aktivációs energia is állhat. Ez az I. típusú SQR enzimekben kialakulóhoz képest valamilyen magasabb energiatartalmú köztitermékre utal. A szulfidra meghatározott $\mathrm{K}_{\mathrm{m}}$ érték mindkét alkalmazott kinon mellett magas, de közel azonos (3. táblázat).

A durokinonnal kapott $209 \mu \mathrm{M}$ egy új nagyságrendet képvisel az eddigi bakteriális SQR enzimeknél mért $K_{m}$ értékek között. 


\begin{tabular}{cccc}
\hline SQR típus & Mikroorganizmus & $\mathbf{K}_{\mathbf{m}}$ (szulfid) & Referencia \\
\hline I. & R. capsulatus & $5 \mu \mathrm{M}$ & {$[65]$} \\
II. & A. marina & $23 \mu \mathrm{M}$ & {$[101]$} \\
III. & C. maquilingensis & $77 \mu \mathrm{M}$ & {$[41]$} \\
V. & A. ambivalens & $2 \mu \mathrm{M}$ & {$[66]$} \\
VI. & C. tepidum & $2 \mathrm{mM}$ & {$[60]$} \\
& T. roseopersicina & $209 \mu \mathrm{M}$ & Ez a munka \\
\hline
\end{tabular}

6. táblázat: SQR típusú fehérjék szulfidra kapott Km értékek

Az SqrF $K_{m(N a 2)}$ értéke jóval magasabb, mint a többi bakteriális $\mathrm{SQR}$ szulfidra kapott $\mathrm{K}_{\mathrm{m}}$ értékek. Ez alól kivételt képez a C. tepidum SqrF enzim $2 \mathrm{mM-os} \mathrm{K}_{\mathrm{m}}$ értékével [60], ez utóbbi az első olyan baktériumban található $\mathrm{SQR}$ enzim, melynek $\mathrm{K}_{\mathrm{m}(\mathrm{Na} 2 \mathrm{~S})}$ értéke a millimólos tartományba esik a mérések szerint (6. táblázat). A számottevő különbségre az egyformán VI. típusú $T$. roseopersicina $\mathrm{SqrF}$ és $C$. tepidum $\mathrm{SqrF}$ enzimek $\mathrm{K}_{\mathrm{m}}$ értéke között magyarázat lehet a két mikroorganizmus SqrF fehérjéi közötti alacsony szekvencia azonosság (32\%), ami alapján nagy eltérések is lehetnek a rokon fehérjék müködésében.

A T. roseopersicina $\mathrm{SqrF}$ enzim magas $\mathrm{K}_{\mathrm{m}\left(\mathrm{Na}_{2} \mathrm{~S}\right)}$ értéke jól mutatja, hogy alacsony szulfidkötő affinitással rendelkezik. Ez az eredmény teljesen korrelál azon génepxressziós vizsgálatokkal, ahol a $T$. roseopersicina $s q r F$ gén kifejeződését vizsgáltam szulfid koncentrációjának függésében. Azt tapasztaltam, hogy a vizsgált szulfid tartományon belül $(0,1-5 \mathrm{mM})$ magasabb koncentráció esetén, 2,5 $\mathrm{mM} \mathrm{Na} 2 \mathrm{~S}$ mellett az sqrF kifejeződése 1 óra elteltével közel 8-szorosára nőtt. Összefoglalva a génexpressziós és kinetikai eredményeket, feltételezéseim szerint azért van a $T$. roseopesicina-ban kettő ugyanolyan reakciót katalizáló SQR fehérje, mert az SqrD és SqrF enzimek segítségével különböző környezeti körülmények között, szulfidot szélesebb koncentráció tartományban tartalmazó élőhelyeken is képesek a sejtek energiát nyerni, fennmaradni, mely evolúciós előnyt jelenthet a számukra. 


\subsection{Az SqrF müködési/katalitikus mechanizmusa}

Az SQR fehérjék ősi, nagyon konzervált enzimek. Csoportosításuk alapja a konzervált szekvencia motívumaik és a bennük található ciszteinek mintázata [59]. Az SQR enzimekben azonosított ciszteinek - hasonlóan a diszulfid reduktáz nagy enzimcsalád többi tagja esetében - fontos szerepet játszhatnak az enzimek aktív centrumában található FADkötésben, a szulfid kötésében és oxidációjában [59]. A T. roseopersicina $\mathrm{SqrF}$ fehérjében 3 konzervált cisztein található: C121; C272; C332, illetve egy cisztein: C49, mely csak erre a fehérjére jellemző.

Kettő cisztein (C121 és C332) a fehérje belsejében található, a FAD kofaktor izoalloxazin csoportját is magában foglaló aktív centrumban, kettő pedig (C272, C49) attól távol, a fehérje ellentétes oldalán a felszínhez közel helyezkedik el. Az A. aeolicus SqrA fehérje 156. cisztein homológjának hiánya a $T$. roseopersicina SqrF enzimben és a T. roseopersicina SqrF enzim aktív centrumában található ciszteinek nagy térbeli távolsága miatt nem képesek diszulfid hidat kialakítani egymással, így az enzim müködési mechanizmusa vélhetően eltérő az eddigi I. [67] és V. típusú [66] enzimekre leírt katalitikus útvonalakhoz képest. Ezért a ciszteineknek az enzim működésében betöltött szerepük vizsgálata érdekében irányított mutagenezissel alaninra cseréltem az említett négy ciszteint.

A mutáns fehérjéket termelő $T$. roseopersicina törzsek előállítása után, a fehérjéket az általam kidolgozott tisztítási metódus alapján tisztítottam. A tisztított fehérjék abszorbancia spektrumai alapján egyértelmü, hogy a C121A mutáns esetében a fehérje FAD kofaktort nem tartalmaz, tehát a 121. cisztein felelős a FAD kötéséért, melyről a vad típusú SqrF esetén bizonyítottam, hogy kovalensen kötött. A többi SqrF variánsok a vad típusú fehérjékhez hasonló spektrummal rendelkeznek, FAD kofaktort tartalmaznak. A vad típusú enzim szulfid függő DQ redukáló aktivitásához hasonló értékeket kaptam a C49A és a C272A esetén. C121A mutáns nem aktív, mely magyarázható a kofaktor hiányával, illetve bizonyítja a FAD eszenciális szerepét a katalízisben. Továbbá nem zárja ki a lehetőséget, hogy a szulfid oxidálásában is szerepe van a 121. ciszteinnek, azonban hiányának hatását az enzim katalítikus folyamatára szulfid függő kinon redukáló aktivitásméréssel kimutatni nem lehet a kofaktor vesztés miatt. A C332A variáns aktivitása számottevően visszaesett (15\%) a vad típusú enzimhez képest, mellyel igazolást nyert, hogy a szulfid függő kinon redukciós reakció végbemeneteléhez nem nélkülözhetetlen, de fontos szerepe van a katalízisben. Ez ellentétben áll az A. ferrooxidans-nál leírtakkal, ahol az SqrA C356A mutáns esetében az 
aktivitás teljesen megszünt [98], továbbá magasabb a maradék aktivitás a $R$. capsulatus C335S mutáns esetén tapasztalt 0,4\%-os aktivitástól [69].

Meghatároztam az aktivitással rendelkező cisztein mutáns enzimek kinetikai paramétereit. Megfigyelhető, hogy a C49A mutáns szulfid felé mutatott affinitása alacsonyabb, mint a vad típusú enzim affinitása, azonban specifikus aktivitása magasabb. A C272A variáns durokinonhoz való affinitás csökkenése magyarázhatja az alacsonyabb aktivitását és a csökkent $k_{\text {cat }}$ értékét is, melyből arra lehet következtetni, hogy a FAD és kinon közti redox folyamatokban, az enzimreakció reduktív felében játszhat szerepet. Irodalmi adatok nem állnak rendelkezésre lehetséges funkciójáról, hiszen ez a cisztein csak a VI. típusú SQR enzimekben van jelen, és eddig még mutánsok nem készültek ilyen típusú fehérjéből. A C332A mutáns egy nagyságrenddel alacsonyabb aktivitású, azonban a mutáció nem befolyásolta a szulfidhoz és a kinonhoz való affinitást, vélhetően nincs közvetlen szerepe az enzimnek sem a szulfiddal sem a kinonnal való reakciójában. Ezek alapján feltételezhetö, hogy a T. roseopersicina SqrF C332 csoportja homológjainak a VI. típusú SQR enzimekben a katalízis során keletkező oxidált kéntermék koordinálásban van szerepe. Elképzelhető, hogy hiánya következtében nehezebben megy végbe az enzim termékeként kialakuló kénlánc képződése, illetve a képződő kénpolimer leválása a szulfid oxidáció helyéről, mely gátlóan hathat az enzim aktivitására.

A ciszteinek szerepét a katalítikus folyamatban bizonyítja, hogy szulfhidril csoportokhoz irreverzibilisen kötődő ágensekkel (jódacetamid, jódecetsav) sikerült gátolni az enzim aktivitását a szubsztrátok jelenlétében (40. ábra). $300 \mu \mathrm{M}$ IAA teljes gátlást eredményezett, mely adat megegyezik a III. típusú SQR enzimnél leírt értékkel [41]. Azonban ha az enzimet csak a gátlószerrel inkubáltam, az enzim aktivitása megmaradt. Mindez azt jelenti, hogy a tisztított SqrF fehérjében nincs olyan -SH csoport, amivel a IAA úgy képes reagálni, hogy ezáltal inaktivvá teszi az enzimet. Tehát az enzim legalább egy olyan ciszteint tartalmaz, mely a katalízisben részt vesz, de a fehérje nem katalizáló állapotában -SH csoportja a gátlószer számára nem elérhető, feltehetően kémiai kötésben áll. A vad típusú és a mutáns SqrF enzimek szulfhidril-csoport reagensel való gátlolhatóságának összehasonlítása alapján a C49A variáns esetében nincs változás a vad típushoz képest. A C272A és a C332A mutánsok esetében a gátlás alacsonyabb jódacetamid koncentrációnál bekövetkezett, amiböl arra következtettem, hogy a C272A és C332A mutáns enzimek sokkal könnyebben gátolhatóak a vad típusú enzimhez képest. 
Feltételezhetően amiatt, hogy az SqrF fehérjében a katalízisben szerepet játszó cisztein(ek) a C272 és a C332 ciszteineknek a hiányában reaktívabban lesznek a IAA-al.

Feltevésem szerint az SqrF enzim szulfid függő kinon redukáló aktivitás gátlása kétféle módon is végbemehet: egyszer olyan ciszteineken keresztül, amelyek a szulfid oxidációjában vesznek részt, másik útvonal pedig az esetlegesen a kinon redukciós folyamat lépéseiben résztvevő ciszteineken keresztül. A C272A mutáns enzim gátolhatósága kisebb mértékben, míg a C332A enzim variáns gátlása számottevően eltér a vad típusú enzimnél tapasztaltakkal. Véleményem szerint ennek az lehet az oka, hogy a katalízisben szerepet játszó valamelyik cisztein mutációjának eredményeként az enzimreakció valamely lépésében vagy lépéseiben lelassul, ezáltal megnyúlik azon időszak a katalízis során, amely alatt az enzim müködésében fontos cisztein -SH csoportja szabaddá válik. Ennek következtében a gátlószer számára hosszabb ideig elérhető a szabaddá vált szulfhidril csoport, melyhez kötve gátolni tudja az enzimet akár alacsonyabb gátlószer koncentráció alkalmazásakor. A FAD kofaktor kötése és a katalízis összefüggését mutatja azon kísérlet, mely során az enzimet szubsztrátjai mellett gátlószer jelenlétében illetve hiányában inkubáltam, majd vizsgáltam az enzim szulfid függő kinon redukáló aktivitását. Igazoltam, hogy a fehérjében lévő kovalensen kötött FAD kötése a katalízis során képes felbomlani, melyet követően a jódacetamid képes támadni a kofaktort kötő cisztein szabaddá vált szulfhidril-csoportját. Mindez akkor jöhet létre, ha ugyanaz a cisztein játszik szerepet a FAD kötésben és a szulfid oxidációban.

Minden eredményt összevetve, felállítottam a $T$. roseopersicina SqrF enzim müködési modelljét, miszerint a 121. ciszteinnek a FAD kofaktor kötése mellett a szulfid oxidációban is eszenciális szerepe van. Feltételezésem szerint a C121 diszulfid hídon keresztül kovalensen köti a FAD kofaktort. Ezt a kapcsolatot képes a szulfid megtámadni és felszakítani, aminek eredményeként egy redox intermedier jön létre, melyben az elektronok a FAD izoalloxazin csoportjára jutnak. Ezt követően a C121 vissza tud kötni a FAD kofaktorhoz. A képződő kénpolimerek épülésére két lehetséges útvonalat állítottam fel. Az egyik lehetőség szerint a keletkező $S^{0-}$ polimertermék a C332 aminosavon épül, majd leválik (44. ábra A útvonal). Másik feltételezett útvonal szerint a képződő termék a FAD-ot kötő C121 és a FAD között épül fel, majd a megfelelő hosszúságú kénpolimer közvetlenül vagy további aminosavakon keresztül jut a 332. ciszteinre (44. ábra B útvonal). Ezen folyamat során a 332. pozícióban lévő cisztein a felépült kéntermék enzimről való lehasításáért lehet felelös. 

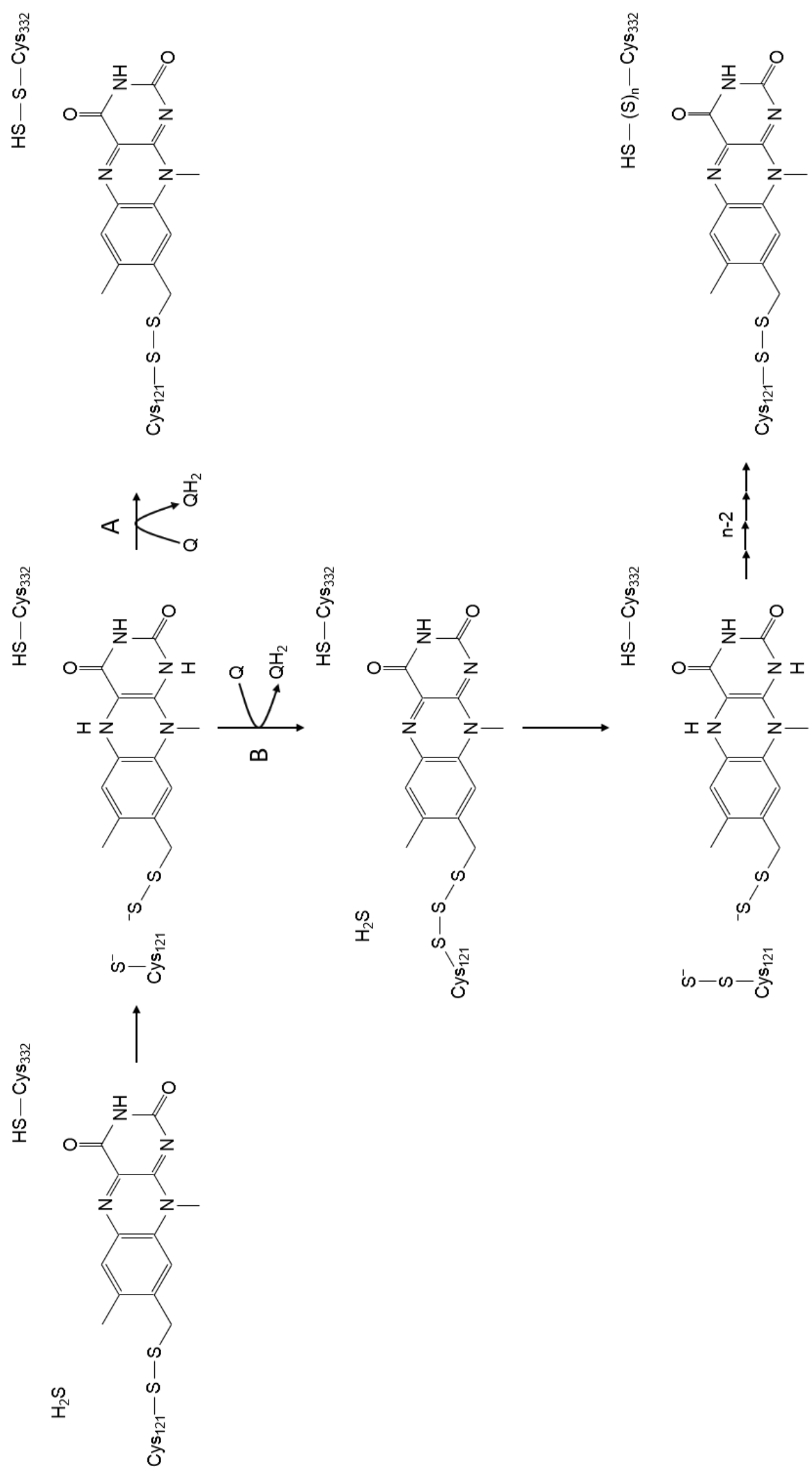


\section{Köszönetnyilvánítás}

Köszönettel tartozom mindenkinek, aki segített abban, hogy ez a munka elkészülhessen. Különösen hálás vagyok témavezetöimnek Dr. Tóth Andrásnak és Dr. Rákhely

Gábornak, hogy vállalták a szakmai irányításomat, ezáltal elindítottak a kutatói pályán. Köszönöm az éveken át tartó türelmüket, iránymutatásukat és önzetlen segítségüket. Köszönöm Katonáné Lehoczky Klárának, hogy bevezetett a „labor-életbe” valamint Verebély Rózsának és Bettynek a barátságukat és a technikai segítséget.

Köszönöm szakdolgozóink (Paula, Bandi, Enikő, Brigi, Vivi, Adri, Niki, Timi, Fanni) szorgalmas munkáját, akikkel mindig élvezetes volt a csapatmunka.

Továbbá köszönettel tartozom az SZTE Biotechnológiai Tanszék és az MTA Szegedi Biológiai Kutatóközpont Biofizikai Intézet minden dolgozójának, a munkám sikeréhez való hozzájárulásukért.

Végül, de nem utolsó sorban mérhetetlen hálát érzek a Családom és Barátaim iránt, akik támogatása nélkül nem tarthatnék itt.

Ezt a tanulmányt Magyarország, Nemzetgazdálkodási Minisztérium támogatta a GINOP2.3.2-15-2016-00001 és a GINOP-2.3.3-15-2016-00006 program keretein belül. 


\section{Hivatkozások jegyzéke}

[1] P. Kamoun, Endogenous production of hydrogen sulfide in mammals, Amino Acids. 26 (2004) 243-254. doi:10.1007/s00726-004-0072-x.

[2] N. Shibuya, S. Koike, M. Tanaka, M. Ishigami-Yuasa, Y. Kimura, Y. Ogasawara, K. Fukui, N. Nagahara, H. Kimura, A novel pathway for the production of hydrogen sulfide from D-cysteine in mammalian cells, Nat. Commun. 4 (2013) 1366. doi:10.1038/ncomms2371.

[3] G.K. Kolluru, X. Shen, C.G. Kevil, A tale of two gases: NO and H2S, foes or friends for life?, Redox Biol. 1 (2013) 313-8. doi:10.1016/j.redox.2013.05.001.

[4] D. Julian, J.L. Statile, S.E. Wohlgemuth, A.J. Arp, Enzymatic hydrogen sulfide production in marine invertebrate tissues, Comp. Biochem. Physiol. Part A Mol. Integr. Physiol. 133 (2002) 105-115. doi:10.1016/S1095-6433(02)00122-8.

[5] G.T. Macfarlane, G.R. Gibson, J.H. Cummings, Comparison of fermentation reactions in different regions of the human colon, J. Appl. Bacteriol. 72 (1992) 5764. doi:10.1111/j.1365-2672.1992.tb04882.x.

[6] P. Nicholls, The effect of sulphide on cytochromeaa3 Isosteric and allosteric shifts of the reduced $\alpha$-peak, Biochim. Biophys. Acta - Bioenerg. 396 (1975) 24-35. doi:10.1016/0005-2728(75)90186-3.

[7] A.K. Mustafa, M.M. Gadalla, N. Sen, S. Kim, W. Mu, S.K. Gazi, R.K. Barrow, G. Yang, R. Wang, S.H. Snyder, H2S signals through protein S-sulfhydration., Sci. Signal. 2 (2009) ra72. doi:10.1126/scisignal.2000464.

[8] R. Hosoki, N. Matsuki, H. Kimura, The Possible Role of Hydrogen Sulfide as an Endogenous Smooth Muscle Relaxant in Synergy with Nitric Oxide, Biochem. Biophys. Res. Commun. 237 (1997) 527-531. doi:10.1006/bbrc.1997.6878.

[9] H. Yan, J. Du, C. Tang, The possible role of hydrogen sulfide on the pathogenesis of spontaneous hypertension in rats., Biochem. Biophys. Res. Commun. 313 (2004) 227. http://www.ncbi.nlm.nih.gov/pubmed/14672692 (accessed April 24, 2017).

[10] D. Lloyd, Hydrogen sulfide: clandestine microbial messenger?, Trends Microbiol. 14 (2006) 456-462. doi:10.1016/j.tim.2006.08.003.

[11] H. Kimura, Hydrogen Sulfide as a Neuromodulator, Mol. Neurobiol. 26 (2002) 013020. doi:10.1385/MN:26:1:013.

[12] S. Völkel, M. Grieshaber, Mechanisms of sulphide tolerance in the peanut worm, Sipunculus nudus (Sipunculidae) and in the lugworm, Arenicola marina (Polychaeta), J. Comp. Physiol. B. 162 (1992) 469-477. doi:10.1007/BF00258971.

[13] J.E. Doeller, M.K. Grieshaber, D.W. Kraus, Chemolithoheterotrophy in a metazoan tissue: thiosulfate production matches ATP demand in ciliated mussel gills, J. Exp. Biol. 204 (2001). http://jeb.biologists.org/content/204/21/3755.short (accessed April $25,2017)$.

[14] J. O'Brien, R.D. Vetter, Production of thiosulphate during sulphide oxidation by mitochondria of the symbiont-containing bivalve Solemya reidi, J. Exp. Biol. 149 (1990). http://jeb.biologists.org/content/149/1/133.short (accessed April 25, 2017).

[15] C. Van Dover, The ecology of deep-sea hydrothermal vents, Princeton University Press, 2000. https://books.google.hu/books?hl=hu\&lr=\&id=uaXuCVuYVDUC\&oi=fnd\&pg=PR $17 \& d q=$ van+Dover+CL+the+ecology+of+deep- 
sea+hydrothermal+vents\&ots=ZJW8a7rg-

A\&sig=nwArb83IdztbxYSspeo5CwbhHRg\&redir_esc=y\#v=onepage\&q=van Dover CL the ecology of deep-sea hydrothermal vent (accessed April 25, 2017).

[16] K.O. Stetter, G. Fiala, G. Huber, R. Huber, A. Segerer, Hyperthermophilic microorganisms, FEMS Microbiol. Lett. 75 (1990) 117-124. doi:10.1111/j.15746968.1990.tb04089.x.

[17] J.M. Macy, I. Schröder, R.K. Thauer, A. Kröger, Growth the Wolinella succinogenes on $\mathrm{H} 2 \mathrm{~S}$ plus fumarate and on formate plus sulfur as energy sources, Arch. Microbiol. 144 (1986) 147-150. doi:10.1007/BF00414725.

[18] C.G. Friedrich, D. Rother, F. Bardischewsky, A. Ouentmeier, J. Fischer, Oxidation of Reduced Inorganic Sulfur Compounds by Bacteria: Emergence of a Common Mechanism?, Appl. Environ. Microbiol. $67 \quad$ (2001) 2873-2882. doi:10.1128/AEM.67.7.2873-2882.2001.

[19] C.G. Friedrich, Physiology and Genetics of Sulfur-oxidizing Bacteria, in: 1997: pp. 235-289. doi:10.1016/S0065-2911(08)60018-1.

[20] D.P. Kelly, A.P. Wood, Reclassification of some species of Thiobacillus to the newly designated genera Acidithiobacillus gen. nov., Halothiobacillus gen. nov. and Thermithiobacillus gen. nov, Int. J. Syst. Evol. Microbiol. 50 (2000) 511-516. doi:10.1099/00207713-50-2-511.

[21] C.G. Friedrich, G. Mitrenga, Oxidation of thiosulfate by Paracoccus denitrificans and other hydrogen bacteria, FEMS Microbiol. Lett. 10 (1981) 209-212. http://www.sciencedirect.com/sdfe/pdf/download/eid/1-s2.00378109781901828/first-page-pdf (accessed April 25, 2017).

[22] M. Aragno, Aerobic chemolithoautotrophic bacteria, in: Thermophilic Bact., 1991: pp. 7-103.

[23] W.R. Strohl, Genus I. Beggiatoa 198920912097, Bergey’s Man. Syst. Bacteriol. 3 (1989). https://scholar.google.com/scholar_lookup?title=Genus I.

Beggiatoa\&author=W. R. Strohl\&publication_year=1989\&journal=Genus I. Beggiatoa\&pages=2091-2097 (accessed April 25, 2017).

[24] J.M.M. Zwart, P.N. Nelisse, J.G. Kuenen, Isolation and characterization of Methylophaga sulfidovorans sp. nov.: an obligately methylotrophic, aerobic, dimethylsulfide oxidizing bacterium from a microbial mat, FEMS Microbiol. Ecol. 20 (1996) 261-270. doi:10.1111/j.1574-6941.1996.tb00324.x.

[25] D.P. Kelly, N.A. Smith, Organic sulfur compounds in the environment biogeochemistry, microbiology, and ecological aspects, in: Adv. Microb. Ecol., Springer US, 1990: pp. 345-385. doi:10.1007/978-1-4684-7612-5_9.

[26] D. P. Kelly, I. R. McDonald, A. P. Wood, Proposal for the reclassification of Thiobacillus novellus as Starkeya novella gen. nov.,comb. nov., in the $\alpha$-subclass of the Proteobacteria, Int. J. Syst. Evol. Microbiol. 50 (2000) 1797-1802.

[27] J. Imhoff, J. Süling, R. Petri, Phylogenetic relationship and taxonomic reclassification of Chromatium species and related purple sulfur bacteria, Int. J. Syst. Bacteriol. (1998).

https://scholar.google.com/scholar?q=Phylogenetic+relationship+and+taxonomic+re classification+of+Chromatium+species+and+related+purple+sulfur+bacteria\&btnG $=\& \mathrm{hl}=\mathrm{hu} \&$ as_sdt=0\%2C5 (accessed April 25, 2017).

[28] D.C. Brune, Sulfur oxidation by phototrophic bacteria, Biochim. Biophys. Acta Bioenerg. 975 (1989) 189-221. doi:10.1016/S0005-2728(89)80251-8.

[29] A. Hiraishi, Y. Ueda, Intrageneric Structure of the Genus Rhodobacter: Transfer of 
Rhodobacter sulfidophilus and Related Marine Species to the Genus Rhodovulum gen. nov., Int. J. Syst. Bacteriol. 44 (1994) 15-23. doi:10.1099/00207713-44-1-15.

[30] E.N. Kondratieva, Chemolithotrophy of phototrophic bacteria, in: Autotroph. Bact., 1989:

pp.

283-287. https://scholar.google.hu/scholar?hl=hu\&q=Kondratieva+E.+N.+\%281989\%29+Ch emolithotrophy+of+phototrophic+bacteria.+in+Autotrophic+bacteria.+eds+Schlegel $+\mathrm{H} .+\mathrm{G} . \% 2 \mathrm{C}+$ Bowien+B.+\%28Springer\%2C+Berlin $\% 2 \mathrm{C}+$ Germany $\% 29 \% 2 \mathrm{C}+\mathrm{pp}+2$ 83-287.+\&btnG $=($ accessed April 25, 2017).

[31] E. Siefert, N. Pfennig, Chemoautotrophic growth of Rhodopseudomonas species with hydrogen and chemotrophic utilization of methanol and formate, Arch. Microbiol. 122 (1979) 177-182. doi:10.1007/BF00411357.

[32] D.C. Brune, Sulfur Compounds as Photosynthetic Electron Donors, in: Anoxygenic Photosynth. Bact., Kluwer Academic Publishers, Dordrecht, 1995: pp. 847-870. doi:10.1007/0-306-47954-0_39.

[33] W. Nitschke, U. Liebl, K. Matsuura, D.M. Kramer, Membrane-bound c-type cytochromes in Heliobacillus mobilis. In vivo study of the hemes involved in electron donation to the photosynthetic reaction center., Biochemistry. 34 (1995) 1183111839.

[34] V. Kostanjevecki, A. Brigé, T.E. Meyer, M.A. Cusanovich, Y. Guisez, J. van Beeumen, A membrane-bound flavocytochrome c-sulfide dehydrogenase from the purple phototrophic sulfur bacterium Ectothiorhodospira vacuolata., J. Bacteriol. 182 (2000) 3097-103. http://www.ncbi.nlm.nih.gov/pubmed/10809687 (accessed April 25, 2017).

[35] T.E. Meyer, M.A. Cusanovich, Discovery and characterization of electron transfer proteins in the photosynthetic bacteria., Photosynth. Res. 76 (2003) 111-126. doi:10.1023/A:1024910323089.

[36] M. Schutz, Y. Shahak, E. Padan, G. Hauska, Sulfide-quinone reductase from Rhodobacter capsulatus. Purification, cloning, and expression., J. Biol. Chem. 272 (1997) 9890-9894.

[37] Y. Shahak, G. Hauska, Sulfide Oxidation from Cyanobacteria to Humans: SulfideQuinone Oxidoreductase (SQR), in: R. Hell, C. Dahl, D. Knaff, T. Leustek (Eds.), Adv. Photosynth. Respir., Springer Netherlands, Dordrecht, 2008: pp. 319-335. doi:10.1007/978-1-4020-6863-8_16.

[38] Z.W. Chen, M. Koh, G. Van Driessche, J.J. Van Beeumen, R.G. Bartsch, T.E. Meyer, M.A. Cusanovich, F.S. Mathews, The structure of flavocytochrome c sulfide dehydrogenase from a purple phototrophic bacterium., Science. 266 (1994) 430-2. http://www.ncbi.nlm.nih.gov/pubmed/7939681 (accessed April 25, 2017).

[39] B.C. Berks, A common export pathway for proteins binding complex redox cofactors?, Mol. $\quad$ Microbiol. $22 \quad$ (1996) 393-404. http://www.ncbi.nlm.nih.gov/pubmed/8939424 (accessed April 25, 2017).

[40] M. Schutz, I. Maldener, C. Griesbeck, G. Hauska, Sulfide-quinone reductase from Rhodobacter capsulatus: requirement for growth, periplasmic localization, and extension of gene sequence analysis., J. Bacteriol. 181 (1999) 6516-6523.

[41] A.M. Lencina, Z. Ding, L.A. Schurig-Briccio, R.B. Gennis, Characterization of the Type III sulfide:quinone oxidoreductase from Caldivirga maquilingensis and its membrane binding, Biochim. Biophys. Acta - Bioenerg. 1827 (2013) 266-275. doi:10.1016/j.bbabio.2012.10.010.

[42] Y. Shahak, B. Arieli, B. Binder, E. Padan, Sulfide-dependent photosynthetic electron 
flow coupled to proton translocation in thylakoids of the cyanobacterium Oscillatoria limnetica., Arch. Biochem. Biophys. 259 (1987) 605-615.

[43] B. Arieli, Y. Shahak, D. Taglicht, G. Hauska, E. Padan, B. Arielis, Y. Shahakn, Purification and characterization of sulfide-quinone reductase, a novel enzyme driving anoxygenic photosynthesis in Oscillatoria limnetica., J. Biol. Chem. 269 (1994) 5705-5711.

[44] L.K. Chan, R.M. Morgan-Kiss, T.E. Hanson, Functional analysis of three sulfide:Quinone oxidoreductase homologs in Chlorobaculum tepidum, J. Bacteriol. 191 (2009) 1026-1034. doi:10.1128/JB.01154-08.

[45] Y. Shahak, B. Arieli, E. Padan, G. Hauska, Sulfide quinone reductase (SQR) activity in Chlorobium., FEBS Lett. 299 (1992) 127-130.

[46] N.-U. Frigaard, D.A. Bryant, Genomic and Evolutionary Perspectives on Sulfur Metabolism in Green Sulfur Bacteria, in: C. Dahl, C.G. Friedrich (Eds.), Microb. Sulfur Metab., Springer Berlin Heidelberg, Berlin, Heidelberg, 2008: pp. 60-76. doi:10.1007/978-3-540-72682-1_6.

[47] N.-U. Frigaard, D.A. Bryant, Genomic Insights into the Sulfur Metabolism of Phototrophic Green Sulfur Bacteria, in: R. Hell, C. Dahl, D. Knaff, T. Leustek (Eds.), Sulfur Metab. Phototrophic Org., Springer Netherlands, Dordrecht, 2008: pp. 337355. doi:10.1007/978-1-4020-6863-8_17.

[48] M. Reinartz, J. Tschape, T. Bruser, H.G. Truper, C. Dahl, Sulfide oxidation in the phototrophic sulfur bacterium Chromatium vinosum., Arch. Microbiol. 170 (1998) 59-68.

[49] C. Dahl, Inorganic Sulfur Compounds as Electron Donors in Purple Sulfur Bacteria, in: R. Hell, C. Dahl, D. Knaff, T. Leustek (Eds.), Sulfur Metab. Phototrophic Org., Springer Netherlands, Dordrecht, 2008: pp. 289-317. doi:10.1007/978-1-4020-68638_15.

[50] T. Nübel, C. Klughammer, R. Huber, G. Hauska, M. Schutz, Sulfide:quinone oxidoreductase in membranes of the hyperthermophilic bacterium Aquifex aeolicus (VF5)., Arch. Microbiol. 173 (2000) 233-244.

[51] Y.-B. Ma, Z.-F. Zhang, M.-Y. Shao, K.-H. Kang, X.-L. Shi, Y.-P. Dong, J.-L. Li, Response of sulfide:quinone oxidoreductase to sulfide exposure in the echiuran worm Urechis unicinctus., Mar. Biotechnol. (NY). 14 (2012) 245-251. doi:10.1007/s10126011-9408-1.

[52] J.G. Vande Weghe, D.W. Ow, A fission yeast gene for mitochondrial sulfide oxidation., J. Biol. Chem. 274 (1999) 13250-13257.

[53] R. Wang, Two's company, three's a crowd: can H2S be the third endogenous gaseous transmitter?, FASEB J. Off. Publ. Fed. Am. Soc. Exp. Biol. 16 (2002) 1792-1798. doi:10.1096/fj.02-0211hyp.

[54] L. Li, P. Rose, P.K. Moore, Hydrogen sulfide and cell signaling., Annu. Rev. Pharmacol. Toxicol. 51 (2011) 169-187. doi:10.1146/annurev-pharmtox-010510100505.

[55] C. Szabo, Gasotransmitters in cancer: from pathophysiology to experimental therapy., Nat. Rev. Drug Discov. 15 (2016) 185-203. doi:10.1038/nrd.2015.1.

[56] U. Theissen, M. Hoffmeister, M. Grieshaber, W. Martin, Single eubacterial origin of eukaryotic sulfide:quinone oxidoreductase, a mitochondrial enzyme conserved from the early evolution of eukaryotes during anoxic and sulfidic times., Mol. Biol. Evol. 20 (2003) 1564-1574. doi:10.1093/molbev/msg174.

[57] V.H. Pham, J.-J. Yong, S.-J. Park, D.-N. Yoon, W.-H. Chung, S.-K. Rhee, Molecular 
analysis of the diversity of the sulfide : quinone reductase (sqr) gene in sediment environments., $\quad$ Microbiology. $\quad 154 \quad$ (2008) 3112-3121. doi:10.1099/mic.0.2008/018580-0.

[58] L.H. Gregersen, D.A. Bryant, N.-U. Frigaard, Mechanisms and evolution of oxidative sulfur metabolism in green sulfur bacteria., Front. Microbiol. 2 (2011) 116. doi:10.3389/fmicb.2011.00116.

[59] M. Marcia, U. Ermler, G. Peng, H. Michel, A new structure-based classification of sulfide:quinone oxidoreductases., Proteins. 78 (2010) 1073-1083. doi:10.1002/prot.22665.

[60] K.E. Shuman, T.E. Hanson, A sulfide:quinone oxidoreductase from Chlorobaculum tepidum displays unusual kinetic properties, FEMS Microbiol. Lett. (2016) fnw100. doi:10.1093/femsle/fnw100.

[61] T. Weissgerber, N. Dobler, T. Polen, J. Latus, Y. Stockdreher, C. Dahl, Genome-wide transcriptional profiling of the purple sulfur bacterium Allochromatium vinosum DSM 180T during growth on different reduced sulfur compounds., J. Bacteriol. 195 (2013) 4231-4245. doi:10.1128/JB.00154-13.

[62] T. Weissgerber, M. Sylvester, L. Kroninger, C. Dahl, A comparative quantitative proteomic study identifies new proteins relevant for sulfur oxidation in the purple sulfur bacterium Allochromatium vinosum., Appl. Environ. Microbiol. 80 (2014) 2279-2292. doi:10.1128/AEM.04182-13.

[63] T. Weissgerber, M. Watanabe, R. Hoefgen, C. Dahl, Metabolomic profiling of the purple sulfur bacterium Allochromatium vinosum during growth on different reduced sulfur compounds and malate, (2014) 1094-1112. doi:10.1007/s11306-014-0649-7.

[64] S. Wakai, M. Tsujita, M. Kikumoto, M.A. Manchur, T. Kanao, K. Kamimura, S.W. Akai, M.T. Sujita, M.K. Ikumoto, M.A.M. Anchur, Purification and characterization of sulfide:quinone oxidoreductase from an acidophilic iron-oxidizing bacterium, Acidithiobacillus ferrooxidans., Biosci. Biotechnol. Biochem. 71 (2007) 2735-2742. doi:10.1271/bbb.70332.

[65] M. Marcia, J.D. Langer, D. Parcej, V. Vogel, G. Peng, H. Michel, Characterizing a monotopic membrane enzyme. Biochemical, enzymatic and crystallization studies on Aquifex aeolicus sulfide:quinone oxidoreductase., Biochim. Biophys. Acta. 1798 (2010) 2114-2123. doi:10.1016/j.bbamem.2010.07.033.

[66] J.A. Brito, F.L. Sousa, M. Stelter, T.M. Bandeiras, C. Vonrhein, M. Teixeira, M.M. Pereira, M. Archer, Structural and functional insights into sulfide:quinone oxidoreductase, Biochemistry. 48 (2009) 5613-5622. doi:10.1021/bi9003827.

[67] M. Marcia, U. Ermler, G. Peng, H. Michel, The structure of Aquifex aeolicus sulfide:quinone oxidoreductase, a basis to understand sulfide detoxification and respiration., Proc. Natl. Acad. Sci. U. S. A. 106 (2009) 9625-9630. doi:10.1073/pnas.0904165106.

[68] M.M. Cherney, Y. Zhang, M. Solomonson, J.H. Weiner, M.N.G. James, Crystal structure of sulfide:quinone oxidoreductase from Acidithiobacillus ferrooxidans: insights into sulfidotrophic respiration and detoxification., J. Mol. Biol. 398 (2010) 292-305. doi:10.1016/j.jmb.2010.03.018.

[69] C. Griesbeck, M. Schutz, T. Schodl, S. Bathe, L. Nausch, N. Mederer, M. Vielreicher, G. Hauska, Mechanism of sulfide-quinone reductase investigated using site-directed mutagenesis and sulfur analysis., Biochemistry. 41 (2002) 11552-11565.

[70] A. Argyrou, M.W. Vetting, J.S. Blanchard, Characterization of a new member of the flavoprotein disulfide reductase family of enzymes from Mycobacterium 
tuberculosis., J. Biol. Chem. 279 (2004) 52694-702. doi:10.1074/jbc.M410704200.

[71] N.U. Frigaard, C. Dahl, Sulfur Metabolism in Phototrophic Sulfur Bacteria, Adv. Microb. Physiol. 54 (2008) 103-200. doi:10.1016/S0065-2911(08)00002-7.

[72] V.M. Gorlenko, Oxidation of thiosulfate by Amoebobacter roseus in darkness in microaerophilic conditions, Mikrobiologiia. 43 (1974) 729-31. http://www.ncbi.nlm.nih.gov/pubmed/4453218 (accessed April 27, 2017).

[73] C. Kampf, N. Pfennig, Capacity of chromatiaceae for chemotrophic growth. Specific respiration rates of Thiocystis violacea and Chromatium vinosum, Arch. Microbiol. 127 (1980) 125-135. doi:10.1007/BF00428016.

[74] E. Kondratieva, R. Ivanovsky, Light and dark metabolism in purple sulfur bacteria, Sci. Rev. (1981).

[75] L. V Bogorov, [The properties of Thiocapsa roseopersicina, strain BBS, isolated from an estuary of the White Sea]., Mikrobiologiia. 43 (1974) 326-332.

[76] P.T. Visscher, J.W. Nijburg, H. van Gemerden, Polysulfide utilization by Thiocapsa roseopersicina, Arch. Microbiol. 155 (1990) 75-81. doi:10.1007/BF00291278.

[77] A. Faou, B.S. Rajagopal, L. Daniels, G. Fauque, Thiosulfate, polythionates and elemental sulfur assimilation and reduction in the bacterial world, FEMS Microbiol. Lett. 75 (1990) 351-381. doi:10.1111/j.1574-6968.1990.tb04107.x.

[78] D. Hensen, D. Sperling, H.G. Trüper, D.C. Brune, C. Dahl, Thiosulphate oxidation in the phototrophic sulphur bacterium Allochromatium vinosum, Mol. Microbiol. 62 (2006) 794-810. doi:10.1111/j.1365-2958.2006.05408.x.

[79] C. Dahl, G. Rakhely, A.S. Pott-Sperling, B. Fodor, M. Takacs, A. Toth, M. Kraeling, K. Győrfi, A. Kovacs, J. Tusz, K.L. Kovacs, Genes involved in hydrogen and sulfur metabolism in phototrophic sulfur bacteria., FEMS Microbiol. Lett. 180 (1999) 317324.

[80] F.M. Asubel, R. Brent, K. R.E., D.D. Moore, J.G. Seidman, J.A. Smith, K. Struhl, Current Protocols in Molecular Biology, Wiley, New York, NY, 1996.

[81] H. Inoue, H. Nojima, H. Okayama, High efficiency transformation of Escherichia coli with plasmids, Gene. 96 (1990) 23-28. doi:10.1016/0378-1119(90)90336-P.

[82] B. Fodor, G. Rakhely, K. AT, K.L. Kovacs, Transposon mutagenesis in purple sulfur photosynthetic bacteria: identification of hypF, encoding a protein capable of processing [ $\mathrm{NiFe}]$ hydrogenases in alpha, beta, and gamma subdivisions of the proteobacteria., Appl. Environ. Microbiol. 67 (2001) 2476-2483. doi:10.1128/AEM.67.6.2476-2483.2001.

[83] H. Yeet Yeang, F. Yusof, L. Abdullah, Protein Purification for the Lowry Assay: Acid Precipitation of Proteins in the Presence of Sodium Dodecyl Sulfate and Other Biological Detergents, Anal. Biochem. 265 (1998) 381-384. doi:10.1006/abio.1998.2893.

[84] R. Tengölcs, L. Mészáros, E. Győri, Z. Doffkay, K.L. Kovács, G. Rákhely, Connection between the membrane electron transport system and Hyn hydrogenase in the purple sulfur bacterium, Thiocapsa roseopersicina BBS, Biochim. Biophys. Acta - Bioenerg. 1837 (2014) 1691-1698. doi:10.1016/j.bbabio.2014.07.021.

[85] V. Solovyev, A. Salamov, Automatic annotation of microbial genomes and metagenomic sequences, Metagenomics. (2011). https://scholar.google.hu/scholar?hl=hu\&q=V.+Solovyev\%2C+A+Salamov+\%2820 $11 \% 29+$ Automatic+Annotation+of+Microbial+Genomes+and+Metagenomic+Sequ ences.+In+Metagenomics+and+its+Applications+in+Agriculture $\% 2 \mathrm{C}+$ Biomedicine + and+Environmental+Studies $+\% 28 \mathrm{Ed} .+\mathrm{R} . \mathrm{W} .+\mathrm{Li} \% 29 \% 2 \mathrm{C}+$ Nova + Science + Publish 
ers\%2C + p.+61-78\&btnG $=($ accessed April 20, 2017).

[86] T. Hirokawa, S. Boon-Chieng, S. Mitaku, SOSUI: classification and secondary structure prediction system for membrane proteins., Bioinformatics. 14 (1998) 378379. doi:10.1093/bioinformatics/14.4.378.

[87] S.Q. Le, O. Gascuel, An improved general amino acid replacement matrix., Mol. Biol. Evol. 25 (2008) 1307-1320. doi:10.1093/molbev/msn067.

[88] K. Tamura, G. Stecher, D. Peterson, A. Filipski, S. Kumar, MEGA6: Molecular Evolutionary Genetics Analysis version 6.0., Mol. Biol. Evol. 30 (2013) 2725-2729. doi:10.1093/molbev/mst197.

[89] T. Kova, B.D. Fodor, K.F. Medzihradszky, L. Kova, Modular Broad-Host-Range Expression Vectors for Single-Protein and Protein Complex Purification, 70 (2004) 712-721. doi:10.1128/AEM.70.2.712.

[90] P. Macheroux, UV-Visible Spectroscopy as a Tool to Study Flavoproteins, in: S.K. Chapman, G.A. Reid (Eds.), Flavoprotein Protoc., Humana Press, Totowa, NJ, 1999: pp. 1-7. doi:10.1385/1-59259-266-X:1.

[91] T. Weissgerber, R. Zigann, D. Bruce, Y.-J. Chang, J.C. Detter, C. Han, L. Hauser, C.D. Jeffries, M. Land, A.C. Munk, R. Tapia, C. Dahl, Complete genome sequence of Allochromatium vinosum DSM 180(T)., Stand. Genomic Sci. 5 (2011) 311-330. doi:10.4056/sigs.2335270.

[92] H. Ding, M.M. Moksa, M. Hirst, J.T. Beatty, Draft Genome Sequences of Six Rhodobacter capsulatus Strains, YW1, YW2, B6, Y262, R121, and DE442., Genome Announc. 2 (2014). doi:10.1128/genomeA.00050-14.

[93] J. Valdes, I. Pedroso, R. Quatrini, R.J. Dodson, H. Tettelin, R. 2nd Blake, J.A. Eisen, D.S. Holmes, Acidithiobacillus ferrooxidans metabolism: from genome sequence to industrial applications., BMC Genomics. 9 (2008) 597. doi:10.1186/1471-2164-9597.

[94] T. Miura, H. Kusada, Y. Kamagata, S. Hanada, N. Kimura, Genome Sequence of the Multiple-beta-Lactam-Antibiotic-Resistant Bacterium Acidovorax sp. Strain MRS7., Genome Announc. 1 (2013). doi:10.1128/genomeA.00412-13.

[95] H. Kuwahara, T. Yoshida, Y. Takaki, S. Shimamura, S. Nishi, M. Harada, K. Matsuyama, K. Takishita, M. Kawato, K. Uematsu, Y. Fujiwara, T. Sato, C. Kato, M. Kitagawa, I. Kato, T. Maruyama, Reduced Genome of the Thioautotrophic Intracellular Symbiont in a Deep-Sea Clam, Calyptogena okutanii, Curr. Biol. 17 (2007) 881-886. doi:10.1016/j.cub.2007.04.039.

[96] A. Gardebrecht, S. Markert, S.M. Sievert, H. Felbeck, A. Thurmer, D. Albrecht, A. Wollherr, J. Kabisch, N. Le Bris, R. Lehmann, R. Daniel, H. Liesegang, M. Hecker, T. Schweder, Physiological homogeneity among the endosymbionts of Riftia pachyptila and Tevnia jerichonana revealed by proteogenomics., ISME J. 6 (2012) 766-776. doi:10.1038/ismej.2011.137.

[97] S. Nakagawa, S. Shimamura, Y. Takaki, Y. Suzuki, S. Murakami, T. Watanabe, S. Fujiyoshi, S. Mino, T. Sawabe, T. Maeda, H. Makita, S. Nemoto, S.-I. Nishimura, H. Watanabe, T. Watsuji, K. Takai, Allying with armored snails: the complete genome of gammaproteobacterial endosymbiont., ISME J. 8 (2014) 40-51. doi:10.1038/ismej.2013.131.

[98] Y. Zhang, J.H. Weiner, Characterization of the kinetics and electron paramagnetic resonance spectroscopic properties of Acidithiobacillus ferrooxidans sulfide:quinone oxidoreductase (SQR)., Arch. Biochem. Biophys. 564 (2014) 110-119. doi:10.1016/j.abb.2014.09.016. 
[99] B. Soballe, R.K. Poole, Microbial ubiquinones: multiple roles in respiration, gene regulation and oxidative stress management, Microbiology. 145 (2008) 1817-1830. doi:10.1099/13500872-145-8-1817.

[100] B. Schoepp-Cothenet, C. Lieutaud, F. Baymann, A. Verméglio, T. Friedrich, D.M. Kramer, W. Nitschke, Menaquinone as pool quinone in a purple bacterium., Proc. Natl. Acad. Sci. U. S. A. 106 (2009) 8549-8554. doi:10.1073/pnas.0813173106.

[101] U. Theissen, W. Martin, Sulfide : quinone oxidoreductase (SQR) from the lugworm Arenicola marina shows cyanide- and thioredoxin-dependent activity., FEBS J. 275 (2008) 1131-1139. doi:10.1111/j.1742-4658.2008.06273.x.

[102] N. Pfennig, H.G. Trüper, The Family Chromatiaceae, in: The Prokaryotes, Springer New York, New York, NY, 1992: pp. 3200-3221. doi:10.1007/978-1-4757-2191$1 \_8$.

[103] G. Rakhely, A.T. Kovacs, G. Maroti, B.D. Fodor, G. Csanadi, D. Latinovics, K.L. Kovacs, Cyanobacterial-type, heteropentameric, NAD+-reducing NiFe hydrogenase in the purple sulfur photosynthetic bacterium Thiocapsa roseopersicina., Appl. Environ. Microbiol. 70 (2004) 722-728.

[104] M. Herrero, V. de Lorenzo, K.N. Timmis, Transposon vectors containing nonantibiotic resistance selection markers for cloning and stable chromosomal insertion of foreign genes in gram-negative bacteria., J. Bacteriol. 172 (1990) 6557-6567.

[105] A. Schäfer, A. Tauch, W. Jager, J. Kalinowski, G. Thierbach, A. Puhler, Small mobilizable multi-purpose cloning vectors derived from the Escherichia coli plasmids pK18 and pK19: selection of defined deletions in the chromosome of Corynebacterium glutamicum., Gene. 145 (1994) 69-73. 


\section{9. Összefoglalás}

A széles körben elterjedt ősi szulfid kinon oxidoreduktáz (SQR) fehérjék részletes megismerése fontos, hiszen számos fontos élettani folyamatban játszanak szerepet. Eukarióta szervezetekben részt vesznek az angiogenezisben, kardiovaszkuláris rendszer továbbá központi idegrendszer müködésében. Az SQR fehérjék közremüködése által lehetséges a minden élőlény számára toxikus szulfid detoxifikálása, homeosztázisának fenntartása. Fotoszintetikus kénbaktériumok esetén pedig a szulfid, mint elektrondonorként való felhasználásában játszanak szerepet.

Kutatásom modellorganizmusa a fototróf bíbor kénbaktérium Thiocapsa roseopersicina genomjának átvizsgálása során azonosítottam két SQR fehérjét kódoló gént: $s q r D$ és $s q r F$. Levezethető termékeik a szulfid kinon oxidoreduktázok IV. (SqrD) és VI. (SqrF) típusába sorolhatóak, melyek a legkevésbé ismert csoportok az SQR fehérjéken belül.

- Különböző szulfid koncentráció mellett végzett génexpressziós vizsgálatokkal igazoltam, hogy az $s q r D$ és $s q r F$ gének promótere szulfiddal indukálható. Az sqrD gén $1 \mathrm{mM}$, míg az sqrF pedig 2,5 mM Na $2 \mathrm{~S}$ jelenlétében érte el génkifejeződésének maximumát, mely előre vetíti annak lehetőségét, hogy a gének termékei különböző $\mathrm{Na}_{2} \mathrm{~S}$ koncentráció mellett játszanak fontos szerepet a sejtekben.

- Az SqrD és SqrF fehérjék fiziológiai és a kénanyagcserében betöltött szerepük bizonyítása végett előállítottam az adott génekben mutáns $T$. roseopersicina törzseket, majd vizsgáltam a sejtek szulfid felhasználási képességét in vivo. Az eredmények alapján kijelenthető, hogy mind az SqrD és SqrF enzim hiánya következtében a sejtek lassabban hasznosították az elektrondonorként szolgáló szulfidot. Tehát mindkét fehérje a $T$. roseopersicina összetett kénanyagcseréjének résztvevője.

- SqrD és SqrF fehérjék részletes biofizikai és biokémiai jellemzése érdekében elöállítottam azon expressziós vektorokat, melyek E. coli és $T$. roseopersicina-ban is képesek rekombináns formában, C- vagy N-terminálison StrepII affinitás peptiddel fúzionáltatva termelni a fehérjéket. Mindkét SQR fehérjét sikeresen expresszáltattam E. coli-ban, azonban a képződő rekombináns fehérjék az oldhatatlan csapadék frakcióban voltak. Továbbiakban a $T$. roseopersicina-ban expresszáltattam a fehérjéket. Az SQR fehérjék membrán-kötöttek, ezért ki kellett dolgoznom az SqrD és SqrF membán fehérjék tisztítására alkalmazható tisztítási protokollt. Legtöbbször 
nem ionos detergensek használatával szabadítják fel a fehérjéket a membránból, ezért számos nem ionos és ikerionos detergenst alkalmaztam egyedül és kombinációban is. SqrD fehérje esetén semmilyen paraméter esetén nem sikerült a tisztítás. A VI. típusú SqrF enzimet ugyan sikerült szolubilizálni, azonban a tisztított fehérje fotoszintetikus pigmentekkel volt szennyezve, így a további biokémiai vizsgálatokra alkalmatlan volt. Másik stratégia a membrán fehérjék tisztítására katotróp sók például nátrium-bromid alkalmazása a fehérjék membránról való leválasztására. Az SqrD fehérjét nem, de az SqrF enzimet sikeresen felszabadítottam a membránból, azonban a tisztított fehérje mennyisége elenyésző volt. Így változtatva a sejtek feltárásán (szferoplast készítés), továbbá a membrán kezelésen (EDTA-val való inkubálás a $\mathrm{NaBr}$ előtt) sikeresen megnöveltem a tisztítható fehérje mennyiségét. Azonban a membrán kezelés után kapott felülúszónak csak bizonyos mennyisége volt pigment mentes, melyből rekombináns SqrF fehérjét lehetett tisztítani. Meghatároztam azon $\mathrm{NaBr}$ koncentráció csökkentés mértékét, amely során a kisebb pigmentekkel teli membrán darabok képesek leülepedni az ultracentrifuga során, de a felszabadított SqrF fehérjék még oldatban maradnak. Az SqrD és SqrF fehérjék tisztíthatóságbeli különbsége adódhat a nem egyforma C-terminális hossz miatt. Ezen régiót teszik felelőssé a membránhoz való kapcsolódásért és annak erősségéért az SQR típusú fehérjékben. A rekombináns SqrF denaturáló gélen egy 44 kDa nagyságú sávként mutatkozik, azonban natív grádiens gélen végzett western analízis során 3 sávot alkot, melyek feltételezhetően a mono- di- és trimer formák. A tisztított SqrF fehérje abszorbancia és fluoreszcens spektruma alapján igazoltam FAD kofaktor tartalmát, mely kovalens módon való kötését szintén kísérletekkel támasztottam alá, valamint bizonyítottam, hogy redox akítv. Meghatároztam, hogy az SqrF enzim szulfid függő kinon redukáló aktivitással bír, elektronakceptorként csak kinont képes elfogadni. Kinon preferencia vizsgálat alapján egyértelmü, hogy az enzim ubikinon típusú kinonokat (decilubikonin, durokinon) részesít előnyben. Durokinon és decilubikinon alkalmazása mellett megvizsgáltam az enzim aktivitás pH-, valamint hőmérséklet függését, mely nem megszokott görbét rajzolt ki. A hőmérsékletfüggési adatokból kiszámoltam az enzim aktivációs energiáját, amely magasabb, mint az eddig leírt enzimnél tapasztalt. Megvizsgáltam az SqrF hőstabilitását, továbbá a szulfid és ko-szubsztrátok függése alapján meghatároztam a kinetikai állandókat. 
- SQR enzimek katalízisében eszenciális szerepet játszanak a konzervált ciszteinek, melyek különböző típusok között változóak. A T. roseopersicina SqrF fehérjében 3 konzervált (C121, C272, C332) és 1 (C49) csak erre az SqrF fehérjére jellemző ciszteint azonosítottam. A fehérje müködésében való szerepük vizsgálata érdekében előállítottam az adott ciszteinekben mutáns fehérjéket termelő $T$. roseopersicina törzseket. A fehérje variánsokat a vad típusú enzimnél alkalmazott általam kidolgozott tisztítási metódussal sikeresen tisztítottam. Abszorbancia spektrumuk alapján megállapítottam, hogy a C121A mutáns kivételével a variánsok FAD kofaktort tatalmaznak, melyből kiderült a 121. cisztein szerepet játszik a FAD kötésében. A C121 további funkcióinak vizsgálata szulfid függő kinon redukáló aktivitás méréssel nem lehetséges, mivel kofaktor hiányában az enzim inaktív. A C49A és C272A mutánsok aktivitása hasonló a vad típusú enzimével, azonban a C332A esetén drasztikusan lecsökkent. Tehát a 332. ciszteinnek fontos szerepe van az enzim müködésében, habár nem eszenciális. Meghatároztam a szulfid és durokinon függés alapján az SqrF variánsok kinetikai paramétereit, melyből arra következtettem, hogy a C272 az enzimreakció reduktív felében játszat szerepet, míg a 332. cisztein a keletkező kéntermék koordinálásában. A ciszteinek szerepének további bizonyítása, hogy szulfhidril csoportokkal irreverzilibisen kapcsolódó ágensekkel (jódacetamid, jódecetsav) sikerült gátolnom az enzim aktivitást. Úgy tünik, hogy a tisztított fehérjében legalább 1 olyan cisztein található, mely $-\mathrm{SH}$ csoportjával reagáló gátlószer képes lenne inaktiválni enzimet, azonban ez a cisztein szulfhidril csoportja kötésben van a nem-katalizáló enzimben. Ezért csak a már a katalízisben résztvevő enzimeket képes a jódacetamid gátolni, azáltal, hogy a reakció során felszabadulnak a gátlásban fontos szerepet játszó ciszteinek - $\mathrm{SH}$ csoportja. Az SqrF variánsok gátlásának a vad típusú enzimével való összehasonlításából arra következtettem, hogy a gátlás megvalósulhat olyan ciszteineken keresztül, melyek az oxidatív lépésben vagy olyan ciszteineken keresztül, melyek a reduktív fázisban játszanak fontos szerepet.

A katalízis és a FAD kofaktor kötés közötti összefüggést kísérletesen bizonyítottam azzal, hogy csak azon denaturált enzim mintából sikerült felszabadítani a FAD-ot, amely aktivitását a szulfhidril csoportokkal reagáló gátlószerrel való kezelés gátolta. Tehát a katalízis során a kofaktor kovalens kötése felbomlik, ezáltal a jódacetamid 
képes támadni a szabaddá vált szulfhidril csoportot, melyböl következik, hogy a C121 a FAD kötés mellett a szulfid oxidációban is fontos szerepet játszik.

- A vad típusú és cisztein mutáns enzimek biofizikai és biokémiai jellemzése, továbbá a gátlási kísérletek során kapott számos adat alapján felállítottam két lehetséges modellt az SqrF enzim müködésére vonatkozóan. 


\section{Summary}

The deeper understanding of the ancient sulfide:quinone oxidoreductase (SQR) proteins is vital, since their involvement in numerous physiological process. Their cardinal role in angiogenesis and further parts of the cardiovascular and central nervous systems was recognised in eukaryotic organisms. The involvement of SQR protein enables the detoxification of the sulfide, considered as toxic to all living organisms, thereby maintaining homeostasis. Amongst the photosynthetic sulfur bacteria this protein is involved in the utilization of sulfide as electron donor.

In the genome of my model organism, phototophic purple sulfur bacterium Thiocapsa roseopersicina BBS, I have identified two SQR protein encoding genes: $s q r D$, $s q r F$. Their gene products can be classified as type IV. (SqrD) and type VI. (SqrF), these are the least of all known groups among between SQR types.

By means of SQR gene expression measurements in the presence of different sulfide concentrations, I proved, that the promoters of the $s q r D$ and $s q r F$ are inducible with $\mathrm{Na}_{2} \mathrm{~S}$. The maximal levels of the gene expression of $s q r D$ and $s q r F$ were observed in $1 \mathrm{mM}$ and $2.5 \mathrm{mM} \mathrm{Na}_{2} \mathrm{~S}$ concentration, respectively, highligthing the possibility that the $\mathrm{SqrD}$ and $\mathrm{SqrF}$ proteins can play important role in the sulfur metabolism of the cells at different $\mathrm{Na}_{2} \mathrm{~S}$ concentrations. In order to verify the physiological roles of SQR enzymes in the metabolism, I created SqrD and SqrF mutant T. roseopersicina strains and investigated their ability for sulfide oxidation. Based on the results, the enzyme mutant strains could utilize the sulfide at lower rate. These facts clearly show that both SqrD and SqrF proteins are taking part in the complex sulfur metabolism of $T$. roseopersicina.

For biophysical and biochemical characterization of SQR proteins, I created expression vectors allowing the expression of the proteins fused C- or N- terminal StrepII affintiy tag in either E. coli or T. roseopersicina strains. Recombinant proteins were successfully expressed in E. coli, but they were found in the fraction of unsoluble cell components. Thus, the recombinant SQR protein expression was performed in $T$. roseopersicina strains.

SQR type proteins are membrane-bound, thus I have had to evolve a purification protocol for the membrane proteins: SqrD and SqrF. In most cases, non-ionic detergents are used to solubilize SQR proteins from the membrane fraction. Hence, in order to release the proteins from the membrane I tested several non-ionic and zwitter ionic detergents, but I could not purify the SqrD protein. The type VI. sulfide:quinone oxidoreductase SqrF protein 
was solubilized and purified, but the fraction containing the protein was contaminated with photosynthetic pigments. Thus, these protein samples was not appropriate for biochemical characterization. Another strategy for the membrane-bound protein solubilization is using chaothropic salts, e.g. sodium-bromide. Using $\mathrm{NaBr}$, the $\mathrm{SqrD}$ protein was not solubilized in contrast to $\mathrm{SqrF}$, which was successfully released from cell membranes by $\mathrm{NaBr}$ treatment.,However, the amount of purified protein was in short supply. To improve the efficiency of protein purification, I modified the disruption method of the cells (creating spheroplasts before cell disruption) and the membrane treatment (incubation in the presence of EDTA before $\mathrm{NaBr}$ addition), which caused higher quantity of purified SqrF. However, I could not purify the SqrF from the whole UC-supernatant after the membrane treatment due to the presence of photosynthetic pigments. I determined the optimal $\mathrm{NaBr}$ concentration, which can keep the solubilized proteins in solution which is free from pigments and other contaminations. The differences in the SqrD and SqrF protein purification features may be due to the different length of $\mathrm{C}$-terminal domain of these proteins. This region might be responsible for the SQR proteins attachment to the membrane and determine the strength of the membrane binding.

The purified SqrF migrated as a sharp band around $44 \mathrm{kDa}$ in SDS-PAGE. In contrast, Western analysis based on native gradient gel revealed three bands, presumably the monomeric, dimeric and trimeric forms of the SqrF enzyme.

Based on the absorption and fluorescent spectra of the purified SqrF, I proved the covalently bound and redox active FAD content of the protein..

I determined that the SqrF can catalyze sulfide-dependent quinone reduction, and the electron acceptor can only be quinones. SqrF prefers ubiquinone type quinones (e.g. decylubiquinone, duroquinone). The $\mathrm{pH}$ and temperature dependences of the enzyme activity were measured using decylubiquinone and duroquinone as substrates. The temperature dependence curves were unconventional, however the activation energy of the enzyme was calculated, which was higher, than the values obtained for other SQR enzymes. I studied the temperature stability of the SqrF, moreover based on the sulfide and cosubstrate dependence of the SqrF activity, kinetic parameters were determined.

Conserved cysteines play essential role in the catalytic mechanism of SQR proteins. The presence and location of these cysteins are varying among different SQR types. $T$. roseopsericina SqrF protein has three conserved cysteins (C121, C272, C332) and one more cysteine, which presents only in this type VI. SQR protein (C49). In order to study the role 
of the cysteines in catalytic mechanism, I constructed cysteine to alanine mutant protein variants. The enzyme variants were succesfully purified. Based on the absorption spectra of purified SqrF variants, the cysteine mutant proteins contain FAD cofactor except for the C121A mutant proving its key role in FAD binding. Although, it is possible that the $\mathrm{C} 121$ has other function in the catalytic mechanism, as well, but its investigation through enzyme activity measurement is not possible, since the enzyme is inactive without cofactor. The C49A and C272A mutant enzymes have almost the same activity as compared to the activity of the wild type protein. Nevertheless, the activity of the C332A variant is drastically decreased highlighting that $\mathrm{C} 332$ has important, but not essential role in the function. Based on the substrate concentration dependence biochemical measurements, the kinetic parameters of the SqrF enzyme variants were determined. This points to the fact that $\mathrm{C} 272$ is taking part in the reductive steps, the $\mathrm{C} 332$ might have role in the coordination of the nascent sulfur product in the catalytic process.

Another approach for clarification of the role of cysteines in catalytic mechanism is the inhibition of SqrF enzyme variants by sulfhydryl blocking agents (iodoacetamide, idoacetic acid). Interestingly, it seems that there is at least one cysteine with a sulfhydryl group, which is unavaible for the inhibitor, hereby the SqrF is still active. Based on the comparison of the enzyme activity inhibition of wild type and the cystein mutants I presumed, that the the enzyme inhibition can proceed in two different ways. In the first version, the inhibiton of the enzyme occur through cysteines, which have role in the oxidative steps of the activity, on the other hand it is also possible that the inhibitor has an effect on the enzyme activity through cysteines, taking part of reductive half-reaction of SqrF.

According to the biophysical and biochemical characterization of wild type and the cysteine mutant enzymes, I created a proposed two alternative models for catalytic mechanism of the SqrF enzyme in T. roseopersicina. 


\section{Függelék}

\subsection{Felhasznált oldatok, törzsek, plazmidok, oligonukleotidok}

\subsubsection{Oldatok összetétele}

Luria-Bertani (LB) tápoldat (1 liter): $10 \mathrm{~g} \mathrm{NaCl}, 10 \mathrm{~g}$ tripton, $5 \mathrm{~g}$ élesztő kivonat.

Pfennig-féle (PC) tápoldat (1 liter): $20 \mathrm{~g} \mathrm{NaCl}, 1 \mathrm{~g} \mathrm{KH} 2 \mathrm{PO}_{4}, 1 \mathrm{~g} \mathrm{MgCl} 2,1 \mathrm{~g} \mathrm{KCl}, 1 \mathrm{~g} \mathrm{NH} 4 \mathrm{Cl}$, $2 \mathrm{~g} \mathrm{NaHCO}_{3}, 4 \mathrm{~g} \mathrm{Na}_{2} \mathrm{~S}_{2} \mathrm{O}_{3}, 20 \mu \mathrm{L} \mathrm{B}_{12}$ vitamin $(1 \mathrm{mg} / \mathrm{mL}), 1 \mathrm{~mL} 20 \mathrm{mM}$ Fe-EDTA, $1 \mathrm{~mL}$ mikroelem oldat.

Mikroelem oldat (1 liter): 2975mg Na2-EDTA, $300 \mathrm{mg} \mathrm{H}_{3} \mathrm{BO}_{4}, 200 \mathrm{mg} \mathrm{CaCl} 2 \cdot 6 \mathrm{H}_{2} \mathrm{O}, 100$ mg $\mathrm{ZnSO}_{4} \cdot 7 \mathrm{H}_{2} \mathrm{O}, 30 \mathrm{mg} \mathrm{MnCl} \cdot 4 \mathrm{H}_{2} \mathrm{O}, 30 \mathrm{mg} \mathrm{Na} 2 \mathrm{MoO}_{4} \cdot 2 \mathrm{H}_{2} \mathrm{O}, 20 \mathrm{mg} \mathrm{NiCl} \cdot 6 \mathrm{H}_{2} \mathrm{O}, 10$ $\mathrm{mg} \mathrm{CuCl} 2 \cdot 2 \mathrm{H}_{2} \mathrm{O}$ [102].

SET puffer: 20 \% szukróz, 50 mM EDTA pH=8,0 és 50 mM Tris- $\mathrm{HCl} \mathrm{pH}=8,00$.

SDS puffer: $20 \% \mathrm{SDS}, 1 \%\left(\mathrm{NH}_{4}\right)_{2} \mathrm{SO}_{4}, \mathrm{pH}=4,80$.

TAE puffer: 4 mM Tris-acetát, 1 mM EDTA pH=8,00.

TB puffer: $10 \mathrm{mM}$ PIPES, $5 \mathrm{mM} \mathrm{CaCl}_{2}, 250 \mathrm{mM} \mathrm{KCl}, 55 \mathrm{mM} \mathrm{MnCl}_{2}, \mathrm{pH}=6,70$.

SOC tápoldat $\left(\mathrm{SOB}+\mathrm{Mg}^{2+}\right)$ (1 liter): $0,5 \mathrm{~g} \mathrm{NaCl}, 20 \mathrm{~g}$ tripton, $5 \mathrm{~g}$ élesztő kivonat, $10 \mathrm{mM}$ $\mathrm{MgSO}_{4}$.

Thiocapsa sóoldat (1 liter): $20 \mathrm{~g} \mathrm{NaCl}, 1 \mathrm{~g} \mathrm{KH}_{2} \mathrm{PO}_{4}, 1 \mathrm{~g} \mathrm{MgCl}, 1 \mathrm{~g} \mathrm{KCl}$.

Konjugációs táptalaj (1 liter): $18 \mathrm{~g} \mathrm{NaCl}, 1 \mathrm{~g} \mathrm{KH}_{2} \mathrm{PO}_{4}, 1 \mathrm{~g} \mathrm{MgCl}_{2}, 1 \mathrm{~g} \mathrm{KCl}, 1 \mathrm{~g} \mathrm{NH} \mathrm{NCl}_{2}, 2$ $\mathrm{g} \mathrm{NaHCO}_{3}, 2 \mathrm{~g}$ Na-acetát, $2 \mathrm{~g} \mathrm{Na}_{2} \mathrm{~S}_{2} \mathrm{O}_{3}, 2$ g Nutrient Broth, 1,5\% Agar, $20 \mu \mathrm{L}$ B12 (1000 $\mu \mathrm{g} / \mathrm{mL}$ ), $1 \mathrm{~mL}$ mikroelem oldat (lásd: 5.2.2.), $1 \mathrm{~mL} 20 \mathrm{mM}$ Fe-EDTA.

PCA lemez (1 liter): $18 \mathrm{~g} \mathrm{NaCl}, 1 \mathrm{~g} \mathrm{KH}_{2} \mathrm{PO}_{4}, 1 \mathrm{~g} \mathrm{MgCl}_{2}, 1 \mathrm{~g} \mathrm{KCl}, 1 \mathrm{~g} \mathrm{NH} 4 \mathrm{Cl}, 2 \mathrm{~g} \mathrm{NaHCO}_{3}$, $2 \mathrm{~g}$ Na-acetát, $2 \mathrm{~g} \mathrm{Na}_{2} \mathrm{~S}_{2} \mathrm{O}_{3}, 7 \mathrm{~g}$ Phyta gél, $20 \mu \mathrm{B} 12(1000 \mu \mathrm{g} / \mathrm{mL}), 1 \mathrm{~mL}$ mikroelem oldat , $1 \mathrm{~mL} 20 \mathrm{mM}$ Fe-EDTA. 
TBS oldat: $50 \mathrm{mM}$ TrisHCl, $150 \mathrm{mM} \mathrm{NaCl} \mathrm{pH=8,00.}$

TBSSL oldat: TBS, 25\% szukróz, 0,1\% lizozim.

Elúciós puffer: $100 \mathrm{mM}$ Tris- $\mathrm{HCl} \mathrm{pH}=8,00,150 \mathrm{mM} \mathrm{NaCl}, 2,5 \mathrm{mM}$ destiobiotin.

Regeneráló puffer: $100 \mathrm{mM}$ Tris- $\mathrm{HCl} \mathrm{pH}=8,00,150 \mathrm{mM} \mathrm{NaCl}, 1 \mathrm{mM}$ HABA (hidroxiazofenil-benzoidsav).

4X SDS felvivő puffer: $100 \mathrm{mM}$ Tris- $\mathrm{HCl}(\mathrm{pH}=6,80), 200 \mathrm{mM}$ DTT, 4\% SDS, 0,2\% brómfenolkék, $20 \%$ glicerin.

TGS puffer (1 liter): $25 \mathrm{mM}$ Tris-Base, $192 \mathrm{mM}$ glicin, 0,1\% SDS pH=8,30

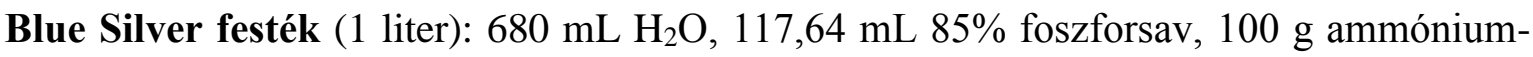
szulfát, 1,2 g Coomassie Blue R-250, 200 mL metanol.

4X Blue-natív felvivő puffer (10 mL): 4 mL 100\% glicerin, 2,5 mL 1M TrisHCl (pH=6,80), 0,02 g Coomassie Brilliant kék (G-250), 3,35 mL $\mathrm{H}_{2} \mathrm{O}$.

Tris-Glicin (TG) puffer (1 liter):25 mM Tris-Base, $192 \mathrm{mM}$ glicin, $\mathrm{pH}=8,30$.

Transzfer puffer (1 liter): $48 \mathrm{mM}$ Tris, $39 \mathrm{mM}$ glicin, 20\% metanol, 1,3 mM SDS pH=9,20.

PBS puffer (1 liter): $115 \mathrm{mM} \mathrm{NaCl}, 4 \mathrm{mM} \mathrm{KH} \mathrm{PO}_{4}, 16 \mathrm{mM} \mathrm{Na}_{2} \mathrm{HPO}_{4}, \mathrm{pH}=7,50$.

PBS-T puffer (1 liter): $115 \mathrm{mM} \mathrm{NaCl}, 4 \mathrm{mM} \mathrm{KH}_{2} \mathrm{PO}_{4}, 16 \mathrm{mM} \mathrm{Na}_{2} \mathrm{HPO}_{4}, 0,1 \%$ Tween 20, $\mathrm{pH}=7,50$.

micro- Lowry C reagens: $6 \% \mathrm{NaHCO}_{3}, 15 \% \mathrm{CuSO}_{4}, 3 \% \mathrm{Na}_{3} \mathrm{C}_{6} \mathrm{H}_{5} \mathrm{O}_{7}$ keverék 50:1 arányú elegye.

SDS-szeparáló gél összetétele: $1,9 \mathrm{ml} \mathrm{H} \mathrm{H}_{2} \mathrm{O}, 1,7 \mathrm{ml} \mathrm{30 \%}$ akrilamid (akrilamid-biszakrilamid: 29:1), 1,3 mL 1,5 M Tris-HCl puffer ( $\mathrm{pH}=8,80), 0,05 \mathrm{~mL} 10 \%$ SDS, 0,05 mL 10\% APS (ammónium-perszulfát) és $3 \mu \mathrm{L}$ TEMED. 
SDS-gyüjtő gél összetétele: $2,1 \mathrm{~mL} \mathrm{H}_{2} \mathrm{O}, 0,5 \mathrm{~mL} 30 \%$ akrilamid (akrilamid-biszakrilamid: 29:1), 0,38 mL 1,5 M-os Tris-HCl puffer (pH=6,80), 0,03 mL 10\% SDS, 0,03 mL 10\% APS és $3 \mu \mathrm{L}$ TEMED.

Natív 5\%-os gél összetétele: $3,15 \mathrm{~mL} \mathrm{H}_{2} \mathrm{O}, 0,920 \mathrm{~mL} 30 \%$ akrilamid (akrilamidbiszakrilamid: 29:1), 1,4 mL 1,5 M Tris- $\mathrm{HCl}$ puffer ( $\mathrm{pH}=8,80), 0,05 \mathrm{~mL} 10 \%$ APS, $3 \mu \mathrm{L}$ TEMED.

Natív 15\%-os gél összetétele: $1 \mathrm{~g}$ szukróz, $0,85 \mathrm{~mL} \mathrm{H}_{2} \mathrm{O}, 2,75 \mathrm{~mL} 30 \%$ akrilamid (akrilamid-biszakrilamid: 29:1), 1,4 mL 1,5 M Tris- $\mathrm{HCl}$ puffer $(\mathrm{pH}=8,80), 0,05 \mathrm{~mL} \mathrm{10 \%}$ APS, $3 \mu \mathrm{L}$ TEMED.

\subsubsection{Thiocapsa roseopersicina törzsek}

\begin{tabular}{|c|c|c|}
\hline Törzsek & Genotípus & Referencia \\
\hline BBS & vad típus & [75] \\
\hline GB1121 & HynSL::Sm${ }^{\mathrm{r}}$ hupSL:: $\mathrm{Gm}^{\mathrm{r}}$ & [103] \\
\hline HOQR & 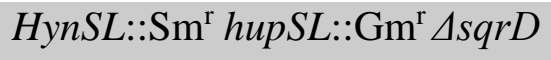 & Ez a munka \\
\hline SOQR & $\mathrm{HOQR}+\mathrm{pDSQR}$ & Ez a munka \\
\hline RSQRN & HOQR + pDSQRNS & Ez a munka \\
\hline HOQN & HynSL::Sm${ }^{\mathrm{r}}$ hupSL:: $\mathrm{Gm}^{\mathrm{r}} \Delta s q r F$ & Ez a munka \\
\hline SOQN & $\mathrm{HOQN}+\mathrm{pDSQN}$ & Ez a munka \\
\hline NSQNN & HOQN + pDSQNNS & Ez a munka \\
\hline C121A & HOQN + pDSQNNSC121A & Ez a munka \\
\hline C272A & HOQN + pDSQNNSC272A & Ez a munka \\
\hline C332A & HOQN + pDSQNNSC332A & Ez a munka \\
\hline C49A & HOQN + pDSQNNSC49A & Ez a munka \\
\hline
\end{tabular}




\begin{tabular}{|c|c|c|}
\hline Törzsek & Genotípus & Referencia \\
\hline S17-1 ( $\lambda$ pir) & $\begin{array}{l}294 \text { (recA pro res mod) } \mathrm{Tp}^{\mathrm{r}} \mathrm{Sm}^{\mathrm{r}} \\
\text { (pRP4-2-Tc::Mu-Km::Tn7) } \\
\text { גpir }\end{array}$ & [104] \\
\hline XL-1 Blue MRF' & 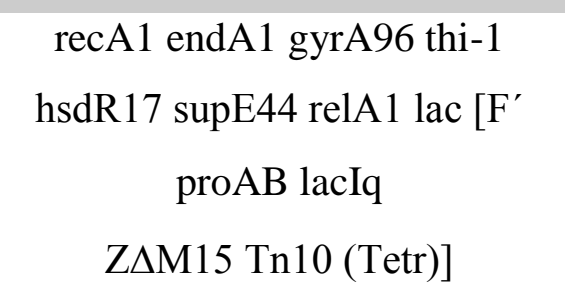 & Stratagene \\
\hline
\end{tabular}

11.1.4. Plazmidok megnevezése és leírása

\begin{tabular}{|c|c|c|}
\hline Plazmidok & Genotípus & Referencia \\
\hline pBluescript SK + & ColE1, Amp ${ }^{r}$ & Stratagene \\
\hline pK18mobsacB & $\begin{array}{l}\text { bhr vektor irányított mutagenezishez, } \\
\qquad \mathrm{Km}^{\mathrm{r}}, \mathrm{sacB}+\end{array}$ & {$[105]$} \\
\hline pDSK6CrtKm & $\begin{array}{c}c r t D \text { gén promóterét tartalmazó } \\
\text { expressziós vektor, } \mathrm{Km}^{\mathrm{r}}\end{array}$ & $\begin{array}{l}\text { (Balogh, } \\
\text { személyes } \\
\text { közlés) }\end{array}$ \\
\hline pBNUP & $\begin{array}{c}\text { sqrF gén,,upstream” régióját tartalmazó } \\
\text { fragment } \\
\text { a pBluescriptSK }(+) \text { plazmidban }\end{array}$ & Ez a munka \\
\hline pBNDO & $\begin{array}{l}\text { sqrF gén,,downstream” régióját } \\
\text { tartalmazó fragment } \\
\text { a pBluescriptSK }(+) \text { plazmidban }\end{array}$ & Ez a munka \\
\hline pKNUP & $\begin{array}{c}s q r F \text { gén,,upstream” régióját tartalmazó } \\
\text { HindIII - PstI fragment a } \\
\text { pK18mobsacB plazmidban }\end{array}$ & Ez a munka \\
\hline
\end{tabular}




\begin{tabular}{|c|c|c|}
\hline pKDSQN & $\begin{array}{c}\text { sqrF gén,,upstream” és „downstream” } \\
\text { homológ régiói a pK18mobsacB } \\
\text { plazmidban, } \mathrm{Km}^{\mathrm{r}}\end{array}$ & Ez a munka \\
\hline pSQRUP & $\begin{array}{c}\text { sqrD gén,,upstream” régióját tartalmazó } \\
\text { fragment } \\
\text { a pBluescriptSK }(+) \text { plazmidban }\end{array}$ & Ez a munka \\
\hline pSQRDO & $\begin{array}{l}\text { sqrD gén,,downstream” régióját } \\
\text { tartalmazó fragment } \\
\text { a pBluescriptSK(+) plazmidban }\end{array}$ & Ez a munka \\
\hline pKSQRUP & $\begin{array}{c}\text { sqrD gén,,upstream” régióját tartalmazó } \\
\text { EcoRI - BamHI fragment a } \\
\text { pK18mobsacB plazmidban }\end{array}$ & Ez a munka \\
\hline pKDSQR & $\begin{array}{c}\text { sqrD gén, ,upstream” és „,downstream” } \\
\text { homológ régiói a pK18mobsacB } \\
\text { plazmidban, } \mathrm{Km}^{\mathrm{r}}\end{array}$ & Ez a munka \\
\hline pBSQR & $\begin{array}{l}s q r D \quad \text { gén a pBluescriptSK }(+) \\
\text { plazmidban }\end{array}$ & Ez a munka \\
\hline pBSQRNS & $\begin{array}{c}\text { N-terminálison StrepII affinitás } \\
\text { peptiddel fúzionáltatott } s q r D \text { gén a } \\
\text { pBluescriptSK(+) plazmidban }\end{array}$ & Ez a munka \\
\hline pDSQR & $\begin{array}{c}\text { C-terminálison StrepII affinitás } \\
\text { peptiddel fúzionáltatott sqrD gén a } \\
\text { pDSK6CrtKm expressziós vektorban, } \\
\mathrm{Km}^{\mathrm{r}}\end{array}$ & Ez a munka \\
\hline pDSQRNS & $\begin{array}{c}\text { N-terminálison StrepII affinitás } \\
\text { peptiddel fúzionáltatott sqrD gén a } \\
\text { pDSK6CrtKm expressziós vektorban, } \\
\mathrm{Km}^{\mathrm{r}}\end{array}$ & Ez a munka \\
\hline pBSQN & $\begin{array}{c}s q r F \text { gén a pBluescriptSK }(+) \\
\text { plazmidban }\end{array}$ & Ez a munka \\
\hline
\end{tabular}




\begin{tabular}{|c|c|c|}
\hline pBSQNNS & $\begin{array}{c}\text { N-terminálison StrepII affinitás } \\
\text { peptiddel fúzionáltatott } s q r F \text { gén a } \\
\text { pBluescriptSK(+) plazmidban }\end{array}$ & Ez a munka \\
\hline pBSQNNSC121A & $\begin{array}{c}\text { C121A pontmutáció a pBSQNNS } \\
\text { vektorban }\end{array}$ & Ez a munka \\
\hline pBSQNNSC272A & $\begin{array}{c}\text { C272A pontmutáció a pBSQNNS } \\
\text { vektorban }\end{array}$ & Ez a munka \\
\hline pBSQNNSC332A & $\begin{array}{c}\text { C332A pontmutáció a pBSQNNS } \\
\text { vektorban }\end{array}$ & Ez a munka \\
\hline pBSQNNSC49A & $\begin{array}{c}\text { C49A pontmutáció a pBSQNNS } \\
\text { vektorban }\end{array}$ & Ez a munka \\
\hline pDSQN & $\begin{array}{c}\text { C-terminálison StrepII affinitás } \\
\text { peptiddel fúzionáltatott } s q r F \text { gén a } \\
\text { pDSK6CrtKmexpressziós vektorban, } \\
\mathrm{Km}^{\mathrm{r}}\end{array}$ & Ez a munka \\
\hline pDSQNNS & $\begin{array}{c}\text { N-terminálison StrepII affinitás } \\
\text { peptiddel fúzionáltatott } s q r F \text { gén a } \\
\text { pDSK6CrtKmexpressziós vektorban, } \\
\mathrm{Km}^{\mathrm{r}}\end{array}$ & Ez a munka \\
\hline pDSQNNSC121A & $\begin{array}{c}\text { C121A pontmutáció a pDSQNNS } \\
\text { expressziós vektorban }\end{array}$ & Ez a munka \\
\hline pDSQNNSC272A & $\begin{array}{c}\text { C272A pontmutáció a pDSQNNS } \\
\text { expressziós vektorban }\end{array}$ & Ez a munka \\
\hline pDSQNNSC332A & $\begin{array}{c}\text { C332A pontmutáció a pDSQNNS } \\
\text { expressziós vektorban }\end{array}$ & Ez a munka \\
\hline pDSQNNSC49A & $\begin{array}{l}\text { C49A pontmutáció a pDSQNNS } \\
\text { expressziós vektorban }\end{array}$ & Ez a munka \\
\hline
\end{tabular}


11.1.5. Oligonukleotidok megnevezése és szekvenciája

\begin{tabular}{|c|c|}
\hline Név & Szekvencia (5' - 3') \\
\hline osqr1F & GAATTCGTTGGCTCCGACCGCTTTGG \\
\hline osqr2R & GGATCCTCTGTGCAGCCTCGTTATGG \\
\hline osqr3F & TCTAGACTACAGGCTTCACGCGATAC \\
\hline osqr4R & AAGCTTTCCTCGAGAGCGAGCTATTC \\
\hline osqr10F & CATATGGCACGAATCCTTATCCT \\
\hline osqr11R & GAATTCATCGGGCAGCATCGACCAAC \\
\hline \multirow[t]{2}{*}{ osqr21F } & CATATGGCCAGCTGGAGCCATCCGCAGTTCGAGAAGAT \\
\hline & CGAGGGCCGCGCACGAATCCTTATCCTCGGAG \\
\hline osqr22R & GAATTCTCAATCGGGCAGCATCGACCAAC \\
\hline osqn3F & AAGCTTCTGTCGAGACCGGCCAAGAG \\
\hline osqn4R & CTGCAGGACTCCGGTGACCCTTAAAC \\
\hline osqn5F & GGATCCGCTTCGAGTGGTGGTATCTG \\
\hline osqn6R & GAATTCCACGCTGCCGTTCGTGAAGG \\
\hline osqn1F & CATATGCATCGCATCACCATCGT \\
\hline osqn2R & GCGGTAGGGGCGCAGATACC \\
\hline \multirow[t]{2}{*}{ osqn11F } & CATATGGCCAGCTGGAGCCATCCGCAGTTCGAGAAGAT \\
\hline & CGAGGGCCGCCATCGCATCACCATCGTCGGTTC \\
\hline osqn12R & CTAGCGGTAGGGGCGCAGATACCAC \\
\hline onC121AF & CACGCCATCACGCCTGCCGAGGGCATCGCTGC \\
\hline onC121AR & GCAGCGATGCCCTCGGCAGGCGTGATGGCGTG \\
\hline onC121AE & AGCACGCCATCACGCCTGC \\
\hline onC272AF & GCAGGCTGATGCCCATGCCCGTGTCCCCGGCTAC \\
\hline onC272AR & GTAGCCGGGGACACGGGCATGGGCATCAGCCTGC \\
\hline onC272AE & TGCAGGCTGATGCCCATGC \\
\hline onC332AF & CAAGGTCGAGCTGGTCGCCATCGTCGACGCCAACG \\
\hline onC332AR & CGTTGGCGTCGACGATGGCGACCAGCTCGACCTTG \\
\hline onC332AE & CAAGGTCGAGCTGGTCGC \\
\hline
\end{tabular}




\begin{tabular}{rr}
\hline onC49AF & GCCTCATCTGGGTCCCCGCCGGGATCCGCAGCGGCGAG \\
onC49AR & CTCGCCGCTGCGGATCCCGGCGGGGACCCAGATGAGGC \\
onC49AE & TCGCCGCTGCGATCCCGGC \\
\hline
\end{tabular}

11.1.6. A kvantitatív real-time PCR során használt oligonukleotidok

\begin{tabular}{cc}
\hline Név & Szekvencia (5' $\mathbf{- 3}$ ') \\
\hline osqrrt1 & CCATCTACAAGAAGCTCGGTGTC \\
osqrrt2 & CCCTCGGGATGGATCGAAAC \\
osqnrt1 & GCCACAAGCTCAAGTCGTTC \\
osqnrt2 & GGCATGAAGAGGATGAGATCAG \\
\hline
\end{tabular}

